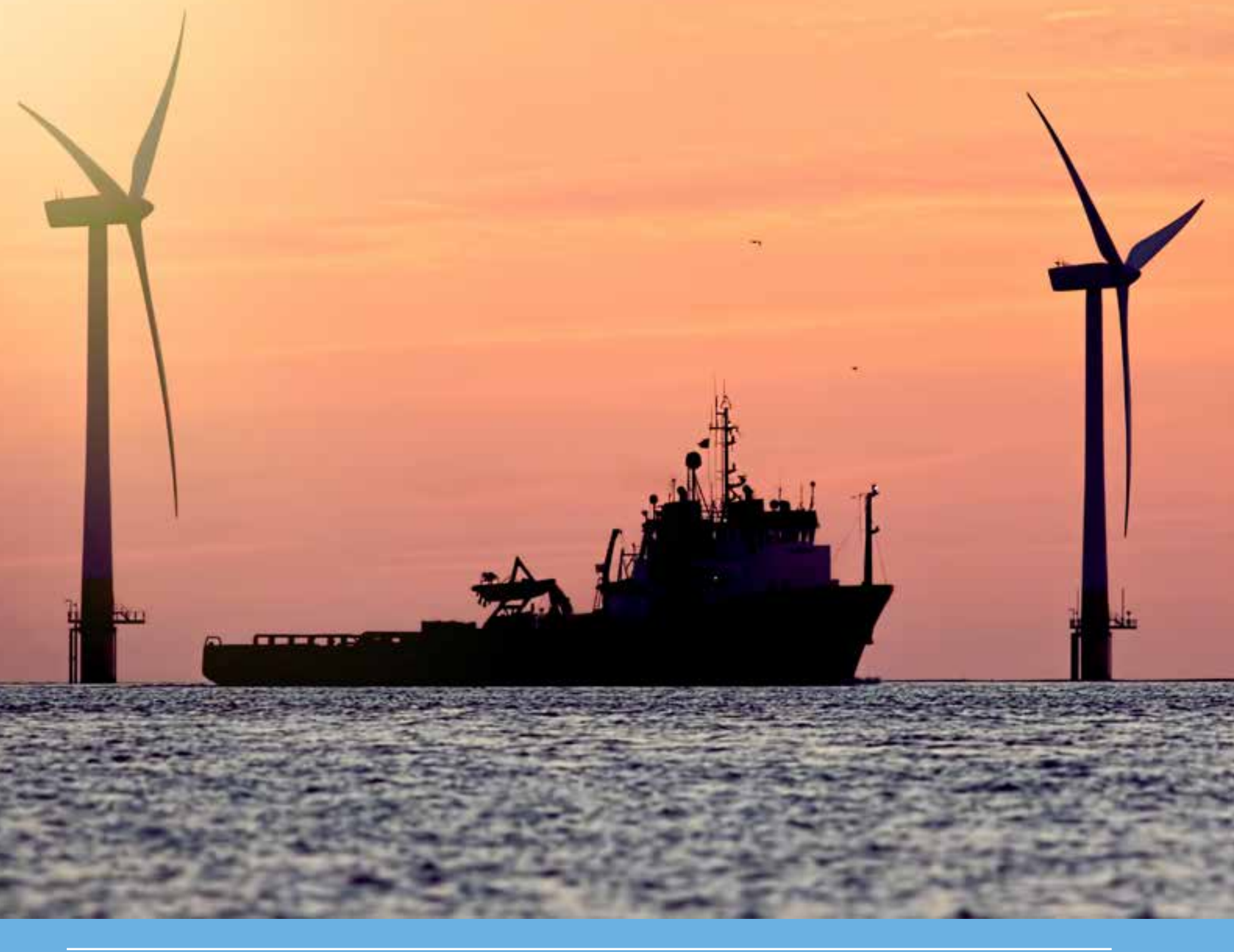

Aanvullende analyse van de economische effecten van inrichtingsvarianten voor de Noordzee tot 2040/2050

Roebeling, P.C., S. van den Burg, W.J. Strietman, K. Hamon, A. Eweg en S. Reinhard

WAGENINGEN UNIVERSITY \& RESEARCH 



\section{Aanvullende analyse van de economische effecten van inrichtingsvarianten voor de Noordzee tot 2040/2050}

Roebeling, P.C., S. van den Burg, W.J. Strietman, K. Hamon, A. Eweg en S. Reinhard

Dit onderzoek is uitgevoerd door Wageningen Economic Research en gesubsidieerd door het ministerie van Ministerie van Infrastructuur en Waterstaat (I\&W), in het kader van het Beleidsondersteunend onderzoeksthema 'Duurzame voedselvoorziening \& -productieketens \& Natuur' (projectnummer BO-43-023.03-013)

Wageningen Economic Research

Wageningen, juni 2021

RAPPORT

2021-069

ISBN 978-94-6395-858-5 
Roebeling, P.C., S. van den Burg, W.J. Strietman, K. Hamon, A. Eweg, \& S. Reinhard, 2021. Aanvullende analyse van de economische effecten van inrichtingsvarianten voor de Noordzee tot 2040/2050. Wageningen, Wageningen Economic Research, Rapport 2021-069. 46 blz.; 17 fig.; 22 tab.; 18 ref.

In deze studie wordt een indicatieve economische vertaling gemaakt van de effecten van verschillende ruimtelijke inrichtingsvarianten op de Noordzee gebruiksfuncties. Hierbij wordt voor elke inrichtingsvariant de effecten waar mogelijk kwantitatief doorgerekend en waar dat niet mogelijk is kwalitatief beoordeeld voor de jaren 2017 en 2040/2050. De economische effecten worden hierbij berekend in termen van de jaarlijkse directe en indirecte productiewaarde, toegevoegde waarde, werkgelegenheid (fte) en mitigatiekosten.

In this report, indicative insight is provided into the economic effects of future spatial scenarios on the North Sea usage functions. For each of these scenarios, the annual effects on the various usage functions on the Dutch part of the North Sea are calculated or qualitatively described for the years 2017 and 2040/2050. The economic effects are calculated in terms of the annual direct and indirect production value, added value, employment (FTE) and mitigation costs.

Trefwoorden: Noordzee, Noordzeebeleid, economische activiteiten, toekomstscenario's, windenergie op zee, visserij, scheepvaart

Dit rapport is gratis te downloaden op https://doi.org/10.18174/548649 of op www.wur.nl/economicresearch (onder Wageningen Economic Research publicaties).

(C) 2021 Wageningen Economic Research

Postbus 29703, 2502 LS Den Haag, T 07033583 30, E communications.ssg@wur.nl, www. wur.nl/economic-research. Wageningen Economic Research is onderdeel van Wageningen University \& Research.

\section{(cc) BY-NC}

Dit werk valt onder een Creative Commons Naamsvermelding-Niet Commercieel 4.0 Internationaallicentie.

(C) Wageningen Economic Research, onderdeel van Stichting Wageningen Research, 2021 De gebruiker mag het werk kopiëren, verspreiden en doorgeven en afgeleide werken maken. Materiaal van derden waarvan in het werk gebruik is gemaakt en waarop intellectuele eigendomsrechten berusten, mogen niet zonder voorafgaande toestemming van derden gebruikt worden. De gebruiker dient bij het werk de door de maker of de licentiegever aangegeven naam te vermelden, maar niet zodanig dat de indruk gewekt wordt dat zij daarmee instemmen met het werk van de gebruiker of het gebruik van het werk. De gebruiker mag het werk niet voor commerciële doeleinden gebruiken.

Wageningen Economic Research aanvaardt geen aansprakelijkheid voor eventuele schade voortvloeiend uit het gebruik van de resultaten van dit onderzoek of de toepassing van de adviezen.

Wageningen Economic Research is ISO 9001:2015 gecertificeerd.

Wageningen Economic Research Rapport 2021-069 | Projectcode 2282700561

Foto omslag: Shutterstock 


\section{Inhoud}

$\begin{array}{ll}\text { Woord vooraf } & 5\end{array}$

$\begin{array}{ll}\text { Samenvatting } & 6\end{array}$

$\begin{array}{lll}\text { S.1 Belangrijkste uitkomsten } & 6\end{array}$

$\begin{array}{ll}\text { S.2 Methode } & 6\end{array}$

\begin{tabular}{l|l} 
Summary & 8
\end{tabular}

$\begin{array}{lll}\text { S.1 Key findings } & 8\end{array}$

$\begin{array}{lll}\text { S.2 Method } & 8\end{array}$

1

Inleiding $\quad 10$

$\begin{array}{lll}1.1 & \text { Aanleiding } & 10\end{array}$

$\begin{array}{lll}1.2 & \text { Doelstelling } & 10\end{array}$

2

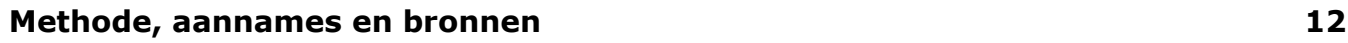

2.1 Methode 12

2.2 Aannames 13

$\begin{array}{lll}2.3 & \text { Bronnen } & 17\end{array}$

3

$\begin{array}{ll}\text { Definitie varianten en subvarianten } & 19\end{array}$

$\begin{array}{llr}\text { Resultaten } & \mathbf{2 1}\end{array}$

4.1 Per sector per WOZ-zoekgebied $\quad 22$

4.2 Per sector per WOZ-zoekgebied per variant $\quad 25$

4.2.1 Windmolenparkexploitatie $\quad 27$

4.2.2 Windmolenparkbouw 30

4.2.3 Visserij 33

4.2.4 Scheepvaart 36

$\begin{array}{lll}4.3 & \text { Per sector per variant } & 37\end{array}$

4.3.1 Windmolenparkexploitatie $\quad 38$

4.3.2 Windmolenparkbouw

$\begin{array}{ll}4.3 .3 \text { Visserij } & 40\end{array}$

$5 \quad$ Discussie, conclusies en aanbevelingen $\quad 41$

$\begin{array}{lll}5.1 & \text { Discussie } & 41\end{array}$

5.2 Conclusies $\quad 42$

$\begin{array}{lll}5.3 & \text { Aanbevelingen } & 42\end{array}$

$\begin{array}{ll}\text { Referenties } & 44\end{array}$ 



\section{Woord vooraf}

De Rijksoverheid is bezig met het opstellen van het Programma Noordzee 2022-2027, waarvoor een uitgebreid participatieproces in gang is gezet dat moet leiden tot een set van afspraken voor de inrichting van de Noordzee voor de lange termijn (2040/2050). Gedurende de periode februari tot en met juni 2020 heeft er een interactief proces van joint-fact-finding met stakeholders plaatsgevonden, waarin werd verkend (aan de hand van een economische en ecologische kentallenanalyse; Roebeling et al., 2021) wat de mogelijke voor- en nadelen van inrichtingsvarianten van de Noordzee zouden zijn. Het idee was dat op basis van dit inzicht in de voor- en nadelen van de verschillende varianten, er een keuze zou kunnen worden gemaakt voor een 'voorkeursvariant'. Het bleek echter dat de effecten van de verschillende varianten te weinig onderscheidend waren om een duidelijke voorkeur uit te kunnen spreken. Bovendien, achtte de Projectgroep Programma Noordzee het raadzaam varianten te optimaliseren en aan te vullen met input van experts en belanghebbenden, en was het nodig een drietal onbenutte delen van al aangewezen windenergiegebieden in de analyse te betrekken.

Met name voor de tijdige aanwijzing van de windgebieden op zee, was het van belang dat voor 1 januari 2021 overeenstemming zou ontstaan over een voorkeursvariant voor de inrichting van de Noordzee in 2040/2050. Als bijdrage aan de discussie over de toekomstige inrichting van de Noordzee, heeft het ministerie van Infrastructuur \& Waterstaat aan Wageningen Economic Research gevraagd een aanvullende Kentallen Analyse uit te voeren. Deze analyse heeft als doel om een inschatting te geven van de ordegroottes van de economische effecten van verschillende herijkte varianten en subvarianten voor de aanwijzing van windenergiegebieden (2040/2050) op het Nederlandse deel van de Noordzee.

Dit rapport geeft inzicht in de economische effecten (in termen van productiewaarde, toegevoegde waarde, werkgelegenheid en mitigatiekosten) van de herijkte varianten en subvarianten voor de aanwijzing van windenergiegebieden (2040/2050) op de Noordzee, op windenergie, visserij en scheepvaart. De economische effecten zijn gebaseerd op sector analyse, sector data en mitigatiekosten. Deze studie laat zien dat er noch WOZ-zoekgebieden noch varianten zijn aan te wijzen die maximale windmolenparkexploitatiebaten combineren met minimale visserij- en scheepvaartkosten. Een optimalisatie methode zou kunnen helpen bij het identificeren van varianten (i.e. combinaties van WOZ-zoekgebieden) die maximale baten combineren met minimale kosten.

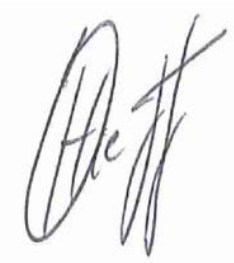

Ir. O. (Olaf) Hietbrink

Business Unit Manager Wageningen Economic Research

Wageningen University \& Research 


\section{Samenvatting}

\section{S.1 Belangrijkste uitkomsten}

- De te vergelijken varianten voor de aanwijzing van windenergie-gebieden (2040/2050) op de Noordzee, zijn gebaseerd op acht wind-op-zee (WOZ) zoekgebieden en drie nog onbenutte delen van reeds aangewezen WOZ-zoekgebieden (zie figuur 3.1). Een variant is een selectie van 4 tot 7 WOZ-zoekgebieden, waarmee een extra capaciteit van $27 \mathrm{GW}$ wordt gerealiseerd (boven op de huidige windparken $(1,0 \mathrm{GW})$ en de windparken die tot 2030 worden aangelegd $(11,5 \mathrm{GW})$ ). Dit leidt tot 6 herijkte varianten ( $A$ tot en met $F$ ) en 11 subvarianten die worden geëvalueerd in deze studie.

- De gederfde toegevoegde waarde van visserij in de WOZ-zoekgebieden is zeer klein ( $<2 \mathrm{mln} . € / j a a r)$ ten opzichte van de respectievelijke toegevoegde waardes van windmolenparkexploitatie ( $>163 \mathrm{mln}$. $€ /$ jaar) en scheepvaart mitigatiekosten (>75 mln. $€ /$ jaar). Verder blijkt dat de windmolenparken met, relatief (per GW), de hoogste exploitatie toegevoegde waarde (WOZ-zoekgebieden HK-noordwest, HKzuidwest, 5+middenberm en 2) grotendeels overeenkomen met de windmolenparken met, relatief (per GW), de hoogste gederfde toegevoegde waarde voor visserij (WOZ-zoekgebieden HK-noordwest, HKzuidwest, 1 en IJ-ver-noord) en de hoogste mitigatiekosten voor scheepvaart (WOZ-zoekgebieden HKnoordwest, HK-zuidwest en 8). Aldus zijn er geen WOZ-zoekgebieden die maximale windmolenparkexploitatiebaten combineren met minimale visserij- en scheepvaartkosten.

- De rentabiliteit van windmolenparkexploitatie (i.e. een positieve exploitatie toegevoegde waarde) is bepalend voor het exploiteren van windmolenparken op zee. Op basis van de hoogste toegevoegde waarde voor windmolenparkexploitatie en de laagste gederfde toegevoegde waarde (visserij) en mitigatiekosten (scheepvaart), worden de grootste netto economische waardes verkregen voor de varianten C-I, D-I en B-I (zie figuur 5.1). Deze varianten hebben WOZ-zoekgebieden 2, IJ-ver-noord, 4 en $5+$ middenberm gemeen. Echter, ook hier zijn er geen varianten die maximale windmolenparken exploitatie baten combineren met minimale visserij en scheepvaart kosten (zie tabel 5.1).

- Een optimalisatie routine zou nuttig zijn in het identificeren van varianten (i.e. combinaties van WOZ-zoekgebieden) die maximale windmolenparken exploitatie baten combineren met minimale visserij en scheepvaart kosten.

\section{S.2 Methode}

- Op basis van de economische effectenanalyse-methode ontwikkeld in Strietman et al. (2019) en toegepast in de Kentallen Analyse Mk.1 (Roebeling et al., 2021), aangevuld met additionele kostenschattingen voor relevante mitigatiemaatregelen, worden de economische effecten voor de startsituatie (2017) en de 6 herijkte varianten ( $A$ tot en met $F$ ) plus (11) subvarianten voor de aanwijzing van windenergie-gebieden (2040/2050) op de Noordzee berekend. Dit voor de sectoren windenergie, visserij en scheepvaart, en aan de hand van economische indicatoren (zoals productiewaarde, toegevoegde waarde, werkgelegenheid en mitigatiekosten). De focus ligt daarbij op het vergelijken van de varianten onderling, en minder op het vergelijken van de varianten met de uitgangssituatie.

- Om een indicatie te krijgen van de richting van de economische effecten van de verschillende ruimtelijke inrichtingsvarianten, wordt gebruikgemaakt van sectoranalyse (Strietman et al., 2019; Roebeling et al., 2021) in combinatie met de VMS-mapping-methode voor visserij (Hintzen et al., 2012) en de mitigatiekostenbenadering voor scheepvaatveiligheid.

- In de sectoranalyse worden de huidige economische waarden (2017) van de sectoren bepaald, worden de groeifactoren voor de toekomstvarianten (2040/2050) per sector geschat en worden de toekomstige economische waarden (2040/2050) van de sectoren berekend. 
- In de VMS-mapping-methode wordt de gemiddelde (over de periode 2010 tot en met 2019) economische waarde (productiewaarde, toegevoegde waarde en werkgelegenheid) berekend voor de gebieden die nog overblijven voor de visserij indien er sluitingen van gebieden plaatsvinden voor windmolenparken zoals die in de inrichtingsvarianten geprojecteerd zijn (2040/2050).

- De berekening van de additionele kostenschattingen voor relevante scheepvaartmitigatiemaatregelen, worden gebaseerd op expertinput, literatuurstudie en nieuwe informatie.

- De belangrijkste gegevensbronnen voor deze studie betreffen de Wageningen Economic Researchpublicaties De economische effecten van twee toekomstscenario's voor de Noordzee (Strietman et al., 2019) en De economische en ecologische effecten van inrichtingsvarianten voor de Noordzee tot 2040/2050 (Roebeling et al., 2021), de PBL-publicatie De toekomst van de Noordzee - De Noordzee in 2030 en 2050: een scenariostudie (PBL, 2018) en het bijbehorende achtergronddocument (PBL, 2019), de CBS-publicatie Economic description of the Dutch North Sea and Coast: 2005, 2010, 2014 (CBS, 2016), CBS (Statline-)gegevens uit de Nationale Rekeningen, de Ecorys-publicatie De Nederlandse Maritieme Cluster (Ecorys, 2018), de PWC-publicatie De economische bijdrage van windenergie op zee (PWC, 2018), de BLIX-publicatie Determination of the cost levels of wind farms (and their grid connections) in new offshore wind energy search areas (BLIX, 2020) en sectordata over de Nederlandse visserij (beheerd door Wageningen Economic Research). 


\section{Summary}

\section{S.1 Key findings}

- The variants to be compared for the designation of wind energy areas (2040/2050) on the North Sea are based on eight search areas for offshore wind (WOZ) and three unused parts of already designated WOZ search areas (see Figure 3.1). A variant is a selection of 4 to 7 WOZ search areas, with which an additional capacity of $27 \mathrm{GW}$ is realized (on top of the current wind farms [1.0 GW] and the wind farms that will be constructed until 2030 [11.5 GW]). This leads to 6 revised variants ( $A$ to $F$ ) and 11 sub-variants that are evaluated in this study.

- The foregone value-added from fishery in the WOZ search areas is very small ( $<2 \mathrm{~m} € /$ year) compared to the respective value-added from wind farm operation ( $>163 \mathrm{~m} € /$ year) and shipping mitigation costs (>75 m€/year). Furthermore, it appears that the wind farms with, relatively (per GW), the highest operation value-added (WOZ search areas HK-northwest, HK-southwest, $5+$ corridor and 2) largely correspond to the wind farms with, relatively (per GW), the highest foregone value-added from fisheries (WOZ search areas HK-northwest, HK-southwest, 1 and IJ-farnorth) and the highest mitigation costs for shipping (WOZ search areas HK-northwest, HK-southwest and 8 ). Thus, there are no WOZ search areas that combine maximum wind farm operation benefits with minimum fisheries and shipping costs.

- The profitability of wind farm operation (i.e. a positive operation value-added) is decisive for the operation of offshore wind farms. Based on the highest value-added from wind farm operation and the lowest foregone value-added (from fisheries) and mitigation costs (for shipping), the largest net economic values are obtained for variants C-I, D-I and B-I (see Figure 5.1). These variants have WOZ search areas 2, IJ-far-north, 4 and 5+corridor in common. However, here too there are no variants that combine maximum wind farm operation benefits with minimum fisheries and shipping costs (see Table 5.1).

- An optimization routine would be useful in identifying variants (i.e. combinations of WOZ search areas) that combine maximum wind farm operation benefits with minimum fisheries and shipping costs.

\section{S.2 Method}

- Based on the economic effects analysis method developed in Strietman et al. (2019) and applied in the Kentallen Analyse Mk.1 (Roebeling et al., 2021), supplemented with additional cost estimates for relevant mitigation measures, the economic effects for the reference situation (2017) and the 6 revised variants (A to F) plus (11) sub-variants are calculated for the designation of wind energy areas (2040/2050) on the North Sea. This for the wind energy, fisheries and shipping sectors, and based on economic indicators (such as production value, value-added, jobs and mitigation costs). The focus is on comparing the variants with each other, and less on comparing the variants with the reference situation.

- Sector analysis (Strietman et al., 2019) in combination with the VMS mapping method for fisheries (Hintzen et al., 2012) and the mitigation cost approach for shipping safety are used to obtain an indication of how the economic effects may develop in the different spatial planning variants.

- The sector analysis determines the current economic values (2017) of the sectors, estimates the growth factors for the future variants (2040/2050) per sector and calculates the sectors' future economic values (2040/2050).

- The VMS mapping method calculates the average (over the period 2010-2019) economic value (production value, value-added and jobs) for the areas remaining for fishing if areas are closed in order to create wind farms as planned in the spatial planning variants (2040/2050). 
- The calculation of additional cost estimates for relevant shipping mitigation measures are based on expert input, literature study and new information.

- The main data sources for this study are the Wageningen Economic Research publications De economische effecten van twee toekomstscenario's voor de Noordzee (Strietman et al, 2019) and De economische en ecologische effecten van inrichtingsvarianten voor de Noordzee tot 2040/2050 (Roebeling et al., 2021), the PBL publication De toekomst van de Noordzee - De Noordzee in 2030 en 2050: een scenariostudie (PBL, 2018) and the accompanying background document (PBL, 2019), the CBS publication Economic description of the Dutch North Sea and Coast: 2005, 2010, 2014 (Statistics Netherlands, 2016), Statistics Netherlands (Statline) data from the Netherlands National Accounts, the Ecorys publication De Nederlandse Maritieme Cluster (Ecorys, 2018), the PWC publication De economische bijdrage van windenergie op zee (PWC, 2018), the BLIX publication Determination of the cost levels of wind farms (and their grid connections) in new offshore wind energy search areas (BLIX, 2020) and sector data on Dutch fisheries (managed by Wageningen Economic Research). 


\section{$1 \quad$ Inleiding}

\section{$1.1 \quad$ Aanleiding}

Het Rijk is momenteel bezig met het opstellen van het Programma Noordzee 2022-2027. Daarvoor is een uitgebreid participatieproces in gang gezet dat moet leiden tot een set van afspraken voor de inrichting van de Noordzee voor de lange termijn (2040/2050). Gedurende de periode februari tot en met juni 2020 heeft er een interactief proces van joint-fact-finding met stakeholders plaatsgevonden, waarin werd verkend (aan de hand van een economische en ecologische kentallenanalyse; Kentallen Analyse Mk.1) wat de mogelijke voor- en nadelen van inrichtingsvarianten van de Noordzee zouden zijn. Het idee was dat op basis van dit inzicht in de voor- en nadelen van de verschillende varianten, er een keuze zou kunnen worden gemaakt voor een 'voorkeursvariant'. Het bleek echter dat de effecten van de verschillende varianten, mede door gebrek aan meer gedetailleerde data, te weinig onderscheidend waren om een duidelijke voorkeur uit te kunnen spreken. Bovendien achtte de Projectgroep Programma Noordzee het raadzaam varianten te optimaliseren en aan te vullen met input van experts en belanghebbenden, en was het nodig een drietal onbenutte delen van al aangewezen windenergiegebieden in de analyse te betrekken. Met name voor de tijdige aanwijzing van de windgebieden op zee, was het van belang dat voor 1 januari 2021 overeenstemming zou ontstaan over een voorkeursvariant voor de inrichting van de Noordzee in 2040/2050.

Als bijdrage aan de discussie over de toekomstige inrichting van de Noordzee, heeft het ministerie van Infrastructuur \& Waterstaat aan Wageningen Economic Research gevraagd een aanvullende Kentallen Analyse uit te voeren. Deze analyse heeft als doel om een inschatting te geven van de ordegroottes van de economische effecten van verschillende varianten voor de aanwijzing van windenergiegebieden (2040/2050) op het Nederlandse deel van de Noordzee.

\subsection{Doelstelling}

Het overkoepelend doel van dit project is, derhalve, een aanvullende economische kentallenanalyse (Kentallen Analyse Mk.2) uit te voeren ter inschatting van de ordegroottes van de economische effecten (in termen van productiewaarde, toegevoegde waarde, werkgelegenheid en mitigatiekosten) van de herijkte varianten en subvarianten voor de aanwijzing van windenergiegebieden (2040/2050) op de Noordzee, op windenergie, visserij en scheepvaart. Dit teneinde bij te dragen aan de onderbouwing van de politieke besluitvorming door het kabinet en de discussies in de expertwerkgroep en het Noordzeeoverleg te ondersteunen. Dit gebeurt zo veel mogelijk op basis van de meest recente informatie (die oktober 2020 beschikbaar is gekomen) en verschillende dichtheden per wind-op-zee (WOZ-)zoekgebied.

Dit rapport geeft een beschrijving van de methode, aannames en bronnen die ten grondslag liggen aan de Kentallen Analyse Mk.2 evenals de resultaten van de economische effecten van 6 herijkte varianten en 11 subvarianten voor de aanwijzing van windenergiegebieden (2040/2050) op de Noordzee, op windenergie, visserij en scheepvaart. De varianten hebben betrekking op een selectie van 4 tot 7 WOZ-zoek-gebieden, waarmee een extra capaciteit van $27 \mathrm{GW}$ wordt gerealiseerd (boven op de huidige windparken (1,0 GW) en de windparken die tot 2030 worden aangelegd (11,5 GW)). De economische kentallenanalyse heeft als doel om een inschatting te geven van de ordegroottes van geselecteerde kosten en baten van de varianten voor de aanwijzing van windenergiegebieden (2040/2050) op de Noordzee. 
Tegen deze achtergrond kan een kentallenanalyse per definitie de verwachte effecten niet exact in kaart brengen, maar kan deze wel helpen om een idee te krijgen bij de richting van de te verwachten effecten en daarmee de relatieve belangrijkheid van de gebieden die in de varianten benoemd staan als gebieden voor windenergie op zee.

In dit rapport bespreken we de methode, aannames en bronnen (Hoofdstuk 2), definiëren we de varianten en subvarianten (Hoofdstuk 3), presenteren we de resultaten voor de te vergelijken varianten en subvarianten per wind-op-zee-zoekgebied en totaal per sector (Hoofdstuk 4) en, tot slot, bediscussiëren we de resultaten, trekken we conclusies en geven we aanbevelingen (Hoofdstuk 5). 


\section{Methode, aannames en bronnen}

Voor de aanpak wordt uitgegaan van de economische effectenanalyse-methode ontwikkeld in Strietman et al. (2019) en toegepast in de Kentallen Analyse Mk.1 (Roebeling et al., 2021), aangevuld met additionele kostenschattingen voor relevante mitigatie-/compensatiemaatregelen (zie sectie 2.1). Voor het doorrekenen van de economische effecten voor de startsituatie (2017) en de 6 herijkte varianten ( $A$ tot en met $F$ ) plus (11) subvarianten voor de aanwijzing van windenergiegebieden (2040/2050) op de Noordzee, hanteren we een aantal algemene uitgangspunten en aannames evenals een aantal gebruiksfunctie specifieke uitgangspunten en aannames (voor de sectoren windenergie, visserij en scheepvaart; zie sectie 2.2). De varianten hebben betrekking op een selectie van 4 tot 7 WOZ-zoek-gebieden waarmee een extra capaciteit van $27 \mathrm{GW}$ wordt gerealiseerd, boven op de huidige windparken (1,0 GW) en de windparken die tot 2030 worden aangelegd $(11,5 \mathrm{GW}$; zie Hoofdstuk 3). De berekeningen zijn gebaseerd op studies en data van BLIX, CBS, Ecorys, PBL, PWC, Ministeries, sectordata beheerd door Wageningen Economic Research en overige informatie betrokken van relevante stakeholders (zie sectie 2.3). De focus ligt daarbij op het vergelijken van de varianten onderling, en minder op het vergelijken van de varianten met de uitgangssituatie.

\section{$2.1 \quad$ Methode}

De berekening van de directe en indirecte economische effecten (op basis van economische indicatoren zoals productiewaarde, toegevoegde waarde, werkgelegenheid en mitigatiekosten) die we in deze studie per gebruiksfunctie (windenergie, visserij en scheepvaart), WOZ-zoekgebied en inrichtingsvariant doorrekenen, worden in drie stappen uitgevoerd. Hieronder beschrijven we per stap in het proces de uitgevoerde acties.

\section{Stap 1: Berekening startsituatie}

De directe en indirecte waardes vormen de basis voor het calculatiemodel. Hierin wordt per gebruiksfunctie op de Noordzee aangegeven wat in het referentiejaar (2017) de startwaarden zijn voor de productiewaarde (PW), toegevoegde waarde (TW) en werkgelegenheid (Werk). Dit ziet er (met voorbeeldgetallen) uit als in tabel 2.1. Zie sectie 2.2 voor de berekening van de startwaardes.

Tabel 2.1 Illustratie calculatiemodel: directe en indirecte productiewaarde ( $P W)$, toegevoegde waarde (TW) en werkgelegenheid (Werk) per gebruiksfunctie (GF) in referentiejaar

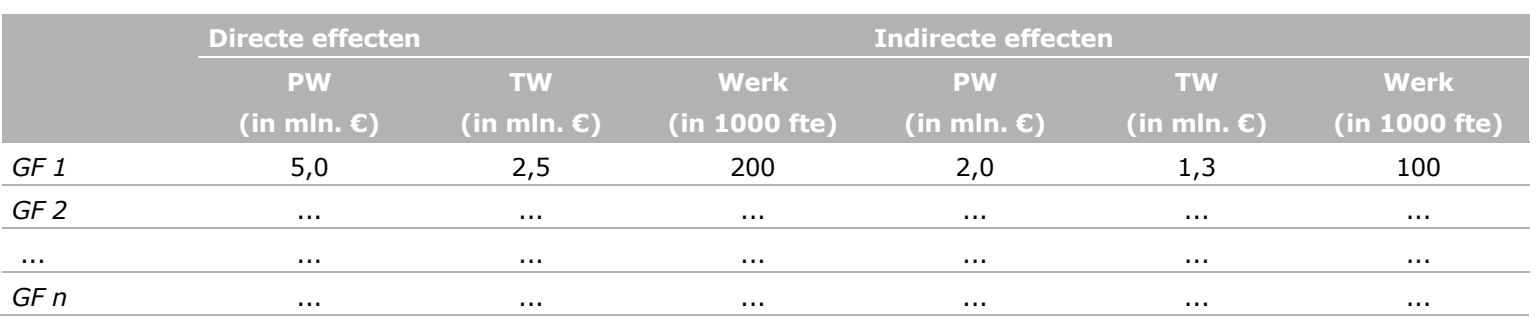

\section{Stap 2: Bepaling van de groeifactoren per gebruiksfunctie en per variant in toekomstjaar} Een groeifactor is het verschil in omvang van een gebruiksfunctie tussen het referentiejaar (2017) en het toekomst jaar (2040/2050) voor een bepaalde variant. Voorbeeld: wordt er in het toekomstjaar (2040/2050) voor een bepaalde gebruiksfunctie ten opzichte van het referentiehaar (2017) in een bepaalde variant een groei van $10 \%$ verwacht, dan is de groeifactor 1,10 (zie tabel 2.2). De groeifactoren die in deze studie gehanteerd worden zijn gebaseerd op de door de opdrachtgever gedefinieerde herijkte varianten en subvarianten (zie Hoofdstuk 3), WOZ-zoekgebieden en bijbehorende achtergrondinformatie (locatie, omvang en intensiteit van gebruiksfuncties). 
Tabel 2.2 Illustratie calculatiemodel: voorbeeld groeifactoren per gebruiksfunctie (GF) en variant in toekomstjaar

\begin{tabular}{lcccc} 
& Variant 1 & Variant 2 & $\ldots$ & \\
GF 1 & 1.10 & 1.15 & $\ldots$ & 1.20 \\
\hline$G F 2$ & $\ldots$ & $\ldots$ & $\ldots$ & $\ldots$ \\
\hline$\ldots$ & $\ldots$ & $\ldots$ & $\ldots$ & $\ldots$ \\
\hline$G F n$ & $\ldots$ & $\ldots$ & $\ldots$ & $\ldots$ \\
\hline
\end{tabular}

Stap 3: Berekening economische impact per gebruiksfunctie en per variant in toekomstjaar Om per variant de omvang van de productiewaarde, toegevoegde waarde en werkgelegenheid te berekenen, worden de groeifactoren voor de varianten vermenigvuldigd met de startwaarden van de productiewaarde, toegevoegde waarde en werkgelegenheid in het referentiejaar (2017). Aldus, voor gebruiksfunctie 1 in Variant 1 zou de omvang dus 1,10 maal de omvang in 2017 zijn (zie tabel 2.3).

Tabel 2.3 Illustratie calculatiemodel: directe en indirecte productiewaarde (PW), toegevoegde waarde (TW) en werkgelegenheid (Werk) per gebruiksfunctie (GF) voor Variant 1 in toekomstjaar

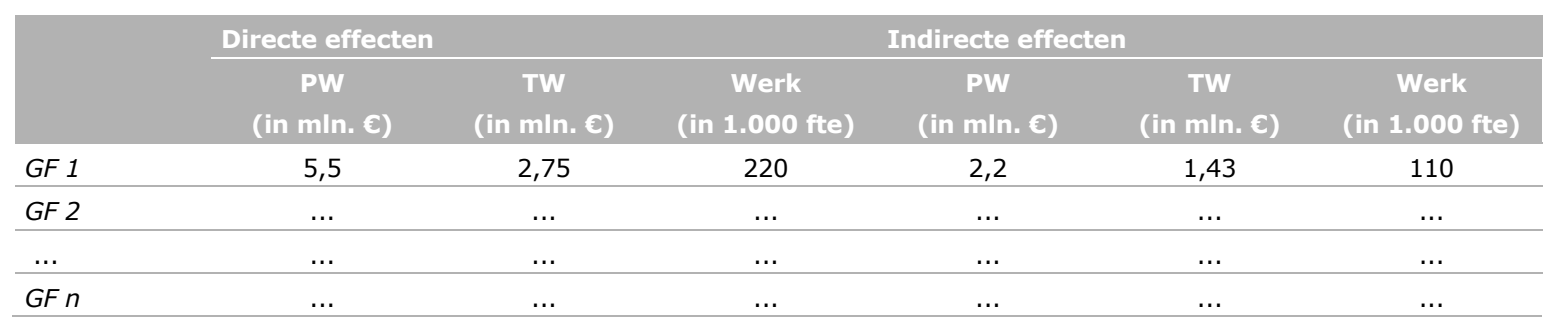

De berekening van de additionele kostenschattingen voor relevante mitigatiemaatregelen, worden gebaseerd op expert input, literatuurstudie en nieuwe informatie die in oktober 2020 beschikbaar is gekomen. Specifiek:

- Scheepvaart: Kosten die gemaakt moeten worden om scheepvaart veiligheid te behouden op huidig (2017) niveau.

\subsection{Aannames}

Op basis van de resultaten van de Kentallen Analyse Mk.1 evenals de hier te vergelijken (6) herijkte varianten en (11) subvarianten voor de aanwijzing van windenergiegebieden (2040/2050) op de Noordzee (zie Hoofdstuk 3), zijn de volgende sectoren meegenomen:

- Windmolenpark aanleg en exploitatie in bestaande en toekomstige WOZ-zoekgebieden met verschillende dichtheden per gebied, kosten voor elektriciteitsinfrastructuur en, waar mogelijk, indicatieve kosten voor transport van moleculen bij windenergiegebieden verder op zee (op basis van nieuwe informatie die in oktober 2020 beschikbaar is gekomen);

- Effecten op visserij doordat, met name, bodem beroerende visserij niet meer mogelijk is in de WOZzoekgebieden; en

- Effecten op scheepvaart met betrekking tot kosten voor mitigerende maatregelen voor de scheepvaartveiligheid (op basis van nieuwe informatie die in oktober 2020 beschikbaar is gekomen).

Voor het doorrekenen van de economische effecten van de herijkte varianten en subvarianten voor de aanwijzing van windenergiegebieden (2040/2050) op de Noordzee, hanteren we een aantal algemene uitgangspunten en aannames evenals een aantal gebruiksfunctie specifieke uitgangspunten en aannames. De algemene uitgangspunten en aannames zijn als volgt:

- Voor deze studie worden de jaarlijkse economische effecten van verschillende ruimtelijke herijkte/subvarianten voor de aanwijzing van windenergiegebieden (2040/2050) op de Noordzee (met gebruiksfuncties) in kaart gebracht voor de ijkjaren 2017 en 2040/2050 op basis van de ruimtelijke inrichtingsvarianten. 
- De meegenomen Noordzee gebruiksfuncties betreffen windenergie, visserij en scheepvaart. De gebruiksfuncties olie- en gaswinning en zandwinning vinden buiten de WOZ-zoekgebieden plaats.

- Deze gebruiksfuncties zijn allen gelokaliseerd op het Nederlands Continentaal Plat (NCP). Het NCP omvat de Noordzee, exclusief de Waddenzee, Oosterschelde en Westerschelde.

- Als indicatoren voor de economische effecten hanteren we de productiewaarde (i.e. de waarde van geproduceerde goederen en diensten), toegevoegde waarde (i.e. productiewaarde minus de kosten van goederen en diensten die als input dienen in het productieproces) en de werkgelegenheid (fte). Voor deze indicatoren is gekozen omdat de productiewaarde een relatie heeft met de milieudruk, de toegevoegde waarde bijdraagt aan het Bruto Nationaal Product en werkgelegenheid als indicatie gebruikt kan worden voor het sociale belang van een gebruiksfunctie.

- Als het gaat om de economische effecten op de productiewaarde, de toegevoegde waarde en de werkgelegenheid, dan bedoelen we daarmee zowel de directe als de indirecte effecten. Waar de directe effecten uitsluitend op het NCP spelen, vinden de indirecte effecten vooral op land plaats. Dit betekent dat we in deze studie zowel de effecten op het NCP als die op land doorrekenen:

- Bij de directe effecten gaat het om de effecten van ruimtelijke inrichtingskeuzes op de productiewaarde, toegevoegde waarde en werkgelegenheid van gebruiksfuncties die op het NCP plaatsvinden.

- Bij de indirecte effecten gaat het om de effecten die ontstaan door de aanvoer van goederen en diensten vanuit Nederland om daarmee de huidige en toekomstige activiteiten binnen de gebruiksfuncties op zee mogelijk te maken. Die goederen en diensten worden grotendeels op land gegenereerd. Denk hierbij bijvoorbeeld aan het produceren van windmolenonderdelen of het leveren van havenfaciliteiten om op de Noordzee windenergie te kunnen produceren.

- Als bron voor informatie over de indirecte economische effecten is grotendeels gebruikgemaakt van de Maritieme Monitor (Ecorys, 2018). Daarin zijn per gebruiksfunctie op basis van inputoutputmodellen de indirecte effecten van verschillende maritieme sectoren (gebruiksfuncties) bepaald. Aangezien in die publicatie geen verdere informatie vermeld staat over welke sectoren in welke mate verantwoordelijk zijn voor deze indirecte effecten, is het (waar wij van deze bron gebruikmaken) niet mogelijk om die in deze studie specifiek te benoemen. Waar we in deze studie gebruik maken van andere bronnen om de indirecte effecten te bepalen, en waar die inzicht geven in de mate waarin welke sectoren hierbij betrokken zijn, geven we dat in deze studie aan.

- In tegenstelling tot de indirecte effecten die ontstaan als gevolg van de aanvoer van goederen en diensten voor gebruiksfuncties op zee, nemen we de indirecte effecten die ontstaan als gevolg van afvoer/verwerking van goederen en diensten vanuit gebruiksfuncties op zee (bijvoorbeeld de economische effecten van de aanvoer van Noordzeevis op de Nederlandse visafslagen) en substitutie-effecten (bijvoorbeeld de invloed van extra windmolenparken op zee op het rendement van Nederlandse kolencentrales) niet mee. Een dergelijke aanvullende exercitie valt buiten de scope van deze studie vanwege het ontbreken van voldoende (betrouwbare) gegevens en cijfers over dergelijke (complexe) effecten.

De sectorspecifieke uitgangspunten en aannames zijn als volgt:

- Windmolenparken op zee

In de berekening van de productiewaarde, toegevoegde waarde en werkgelegenheid in relatie tot windmolenparken op zee, maken we onderscheid tussen 'Exploitatie' (i.e. productie en aanlanding) en 'Bouw' (i.e. aanleg en vervanging). In 2017 was er een totaal areaal van $134 \mathrm{~km}^{2}$ aan windmolenparken op zee, met een totale capaciteit van $\sim 1 \mathrm{GW}$. De doelstelling is dat de totale capaciteit groeit naar 11,5 GW in 2030 en tot 38,5 GW in 2040/2050 (i.e. +27 GW ten opzichte van 2030, conform de gedefinieerde varianten; zie Hoofdstuk 3).

De bronnen voor de berekeningen betreffen CBS (2016), de Maritieme Monitor (Ecorys, 2017), het rapport Energieakkoord - effecten van de energietransitie op de inzet en kwaliteit van arbeid (EIB, 2016), de deliverable Synthesis of available studies on offshore meshed HVDC grids (PROMOTioN, 2016), de studie Connecting offshore wind farms - a comparison of offshore electricity grid development models in Northwest Europe (Navigant, 2019), het rapport De economische bijdrage van windenergie op zee (PWC, 2018) en het rapport Determination of the cost levels of wind farms (and their grid connections) in new offshore wind energy search areas (BLIX, 2020). Alle waardes zijn teruggerekend naar annuïteiten in euro's van 2017. Voor een overzicht van de waardes per windmolenpark, zie sectie 4.1. 


\section{- Exploitatie}

De productiewaarde tijdens de exploitatiefase bestaat uit de levering van elektriciteit uit windmolenparken op zee. De productiewaarde per wind-op-zee (WOZ-)zoekgebied is gebaseerd op BLIX (2020), waarbij wordt uitgegaan van gemiddeld een dichtheid van $\sim 0,7$ turbines $/ \mathrm{km}^{2}$ en een netto-opbrengst van $\sim 65,2 \mathrm{GWh}$ /turbine/jaar. We hanteren een tenderprijs van 4,15 eurocent/kWh in 2040/2050. Er wordt aangenomen dat de Nederlandse economie volledig (100\%) profiteert van de exploitatie van windmolenparken op het NCP.

Tabel 2.4 Gemiddelde kosten per onderdeel per MW (x 1.000 euro); het onderdeel operatie en onderhoud is per MW per jaar (x 1.000 euro)

\begin{tabular}{|c|c|c|}
\hline & Bron & $2040 / 2050$ \\
\hline \multicolumn{3}{|l|}{ Offshore windfarm: } \\
\hline - Ontwerp \& ontwikkeling & PWC (2018) & 71 \\
\hline - Turbines & PWC (2018) & 1.494 \\
\hline - Funderingen & PWC (2018) & 302 \\
\hline - Substations \& bekabeling (inter-array) & PWC (2018) & 520 \\
\hline - Logistiek \& installatie & PWC (2018) & 149 \\
\hline - Operatie \& onderhoud & PWC (2018) & 36 \\
\hline - Ontmanteling \& hergebruik & PWC (2018) & 196 \\
\hline \multicolumn{3}{|l|}{ Grid connection system (HVAC) } \\
\hline - Platform \& converter & Navigant (2019) & 202 \\
\hline - Landstation & Navigant (2019) & 56 \\
\hline - Bekabeling & Navigant (2019) & 162 \\
\hline - Logistiek \& installatie & Navigant (2019) & 38 \\
\hline - Operatie \& onderhoud & Navigant (2019) & 4 \\
\hline \multicolumn{3}{|l|}{ Grid connection system (HVDC) } \\
\hline - Platform \& converter & PROMOTION (2016) & 456 \\
\hline - Landstation & PROMOTioN (2016) & 118 \\
\hline - Bekabeling & PROMOTioN (2016) & 218 \\
\hline - Logistiek \& installatie & PROMOTION (2016) & 76 \\
\hline - Operatie \& onderhoud & PROMOTION (2016) & 13 \\
\hline
\end{tabular}

De toegevoegde waarde is bepaald door het verschil tussen de productiewaarde en de productiekosten. De productiekosten zijn, conform Strietman et al. (2019), gebaseerd op PWC (2018), uitgebreid met aanlandingskosten (PROMOTioN, 2016: Navigant, 2019) en gespecifieerd per WOZ-zoekgebied (BLIX, 2020) (zie tabel 2.4). De gemiddelde productiekosten per WOZzoekgebied komen uit op 3,85 eurocent/kWh in 2040/2050 (gegeven levensduur van 30 jaar). Tijdens de exploitatiefase bestaat de werkgelegenheid met name uit operatie \& onderhoud. Hierbij gaan we uit van 0,10 (directe) fte per MW in combinatie met een HVAC aansluiting (conform Strietman et al., 2019) en 0,13 (directe) fte per MW in combinatie met een HVDC aansluiting (op basis van PROMOTioN, 2016), gebaseerd op de aanname dat er bij een opgesteld vermogen van 11,5 GW de werkgelegenheid een bandbreedte heeft van 550-1.350 fte (Knol, 2018).

Het is, conform de geraadpleegde bronnen in Strietman et al. (2019), niet bekend wat de indirecte effecten zijn op het gebied van productiewaarde, toegevoegde waarde en werkgelegenheid. Hiervoor nemen wij PM-posten op.

- Bouw

De productiewaarde tijdens de bouwfase bestaat uit het ontwerp \& ontwikkeling, bouw van turbines, funderingen en substations \& bekabeling, logistiek \& installatie, ontmanteling \& hergebruik en aanlanding van windmolenparken op zee (zie tabel 2.4). De productiewaarde voor de bouw van windmolenparken komt daarmee overeen met die van de productiekosten (minus operatie \& onderhoud) in de exploitatiefase (zie boven), wat correspondeert met $~ 3,79$ eurocent/kWh in 2040/2050 (gegeven levensduur van 30 jaar). Bij de berekening van de productiewaarde wordt rekening gehouden met het feit dat de Nederlandse economie een gemiddelde bijdrage realiseert van (slechts) $36 \%$ in de ontwikkeling, bouw en onderhoud van windmolenparken op het NCP (PWC, 2018). 
Om een indicatie te krijgen van de toegevoegde waarde wordt, conform Strietman et al. (2019), de verhouding tussen de productiewaarde en toegevoegde waarde en het aantal werkzame personen (fte) van SBI-09 (Dienstverlening Delfstoffenwinning) in 2016, uit de Nationale Rekeningen van CBS (2018), gebruikt. Daarbij genereert 1 fte ruim 550.000 Euro omzet (productiewaarde) en bijna 200.000 euro toegevoegde waarde. Ofwel $36 \%$ van de productiewaarde is toegevoegde waarde.

Voor de berekening van het aantal fte per megawatt voor een windmolenpark op het NCP hanteren we, conform Strietman et al. (2019), de getallen die in het EIB-rapport (EIB, 2016) vermeld staan. Daarmee komt het aantal jaarlijkse (directe) fte per MW voor de bouw van een windmolenpark op zee gemiddeld uit op circa 3,3 in combinatie met een HVAC aansluiting (conform Strietman et al., 2019) en 4,6 in combinatie met een HVDC aansluiting (op basis van PROMOTiON (2016). Hierbij wordt aangenomen dat de Nederlandse werkgelegenheid volledig $(100 \%)$ profiteert van de bouw van windmolenparken op het NCP.

De omrekeningsfactoren voor direct naar indirect bedragen, conform Strietman et al. (2019) en op basis van PWC (2018), 0,47 voor productiewaarde, toegevoegde waarde en werkgelegenheid.

- Visserij

De berekening van de economische waarde (i.e. productiewaarde, toegevoegde waarde en werkgelegenheid) van de verschillende typen visserij in de WOZ-zoekgebieden is gebaseerd op de methode gehanteerd in Hintzen et al. (2012; zie Deetman et al., 2020). De economische waarde van de WOZ-zoekgebieden is daarbij gebaseerd op de waarden die die gebieden vertegenwoordigen voor dredge visserij (onder andere op spisula en ensis), staandwant en overige typen kleine zeevisserij (onder andere op tong en zeebaars), pelagische visserij (onder andere op makreel, haring en wijting), borden, twinrig, quadrig, etc. visserij (onder andere op schol en kreeftjes), flyshoot visserij (onder andere op mul en poon), boomkor, puls en sumwing visserij (onder andere op schol en tong) en, tot slot, garnalenvisserij.

De basisgegevens voor de analyse van de waarde van de verschillende gebieden voor de visserij zijn: de Vessel Monitoring System (VMS-)gegevens, de officiële logboekgegevens, de afslaggegevens en de economische gegevens van de visserij zoals verzameld door Wageningen Economic Research. Al deze gegevens worden per schip bijgehouden:

- De VMS-gegevens geven inzicht in de locatie en vaarsnelheid van de schepen tijdens een visreis (tijdsinterval voor posities is gemiddeld twee uur);

- De logboekgegevens geven inzicht in de aangevoerde hoeveelheid vis, het gebruikte vistuig en fte per visreis; en

- De afslaggegevens geven inzicht in de prijs die op de afslag voor de vis betaald is en de economische gegevens geven inzicht in de verhoudingen tussen de aanvoerwaarde en de toegevoegde waarde per type visserij (i.e. 57\%).

Door deze gegevens te combineren kunnen de opbrengsten van visgebieden voor de verschillende typen visserij bepaald worden. Voor deze analyse vormen de gegevens van Nederlands gevlagde schepen in de periode 2010 tot en met 2019 de basis, waarbij gemiddelde waardes over deze periode worden gebruikt (Deetman et al., 2020). Alle waardes zijn in Euro's van 2017.

De omrekeningsfactoren voor direct naar indirect bedragen, conform Strietman et al. (2019) en op basis van input-outputtabellen van het CBS, 0,40 voor productiewaarde, 0,40 voor toegevoegde waarde en 0,70 voor werkgelegenheid.

\section{- Scheepvaart}

De effecten van de WOZ-zoekgebieden op scheepvaart zijn gebaseerd op de mitigatiekosten die gemaakt moeten worden om de scheepvaartveiligheid te behouden op het peil van dat in 2017. Dit op basis van nieuwe informatie die in oktober 2020 beschikbaar is gekomen (RWS-ZD, 2020), waarin als volgt te werk is gegaan:

1. Grove kwalitatieve inschatting van scheepvaart risico per WOZ-zoekgebied, uitgedrukt in wegingsfactoren ( $w_{\text {geb }}$; zie figuur 2.1 );

2. Inschatting mitigatiekosten op basis van het maatregelenpakket voor de WOZ-zoekgebieden in de Routekaart 2023 (geschat op in totaal 240,6 miljoen euro (prijspeil 2018) voor een gebied van $1.283 \mathrm{~km}^{2}$ ); en

3. Omrekening mitigatiekosten voor WOZ-zoekgebieden naar prijs per $\mathrm{km}^{2}$ per jaar ( $p_{\text {mit }}$; ongeveer 20.000 euro $/ \mathrm{km}^{2} /$ jaar (prijspeil 2019) of 19.149 euro $/ \mathrm{km}^{2} /$ jaar (prijspeil 2017)). 


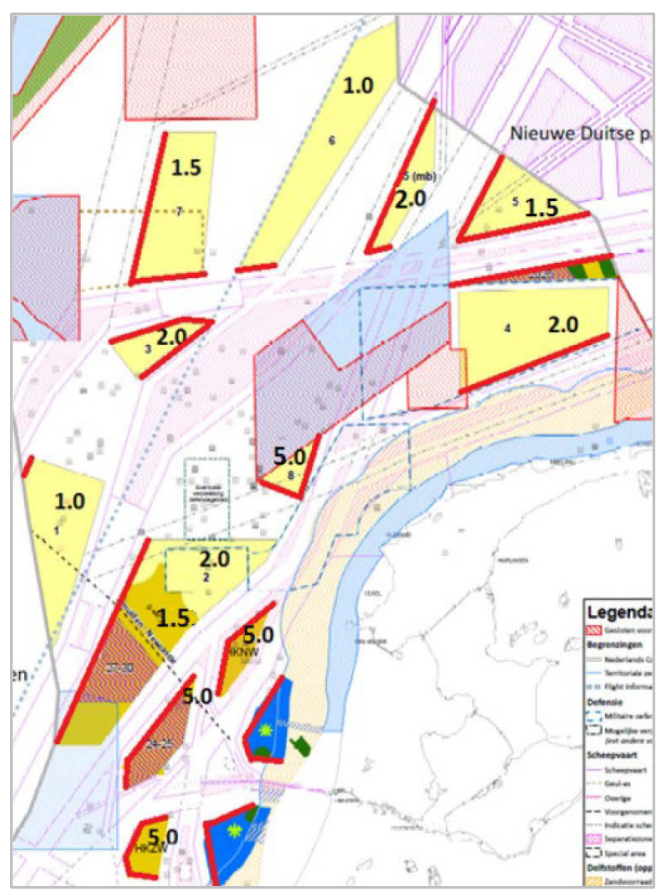

\begin{tabular}{lc} 
Woz-zoekgebied & Risico wegingsfactor \\
Gebied 1 & 1 \\
\hline Gebied 2 & 2 \\
\hline IJ-ver-noord & 1,5 \\
\hline Gebied 3 & 2 \\
\hline Gebied 4 & 2 \\
\hline $5+$ middenberm & 1,75 \\
\hline Gebied 6 & 1 \\
\hline 7 staand & 1,5 \\
\hline Gebied 8 & 5 \\
\hline HK-noordwest & 5 \\
\hline HK-zuidwest & 5
\end{tabular}

Figuur 2.1 Scheepvaartrisico wegingsfactoren voor de wind-op-zee (WOZ-)zoekgebieden 2040/2050

Bron: RWS-ZD (2020).

De mitigatiekosten voor scheepvaart per WOZ-zoekgebied ( $C_{\text {mit; }}$ in $€ /$ jaar) worden nu als volgt berekend:

$$
C_{m i t}=a_{g e b} * p_{m i t} * w_{g e b}
$$

waar $a_{g e b}$ overeenkomt met de oppervlakte van het WOZ-zoekgebied. Alle waardes zijn in euro's van 2017. Aanvullend zijn de volgende aanpassingen toegepast:

- Bij de grote of ruim ingerichte WOZ-zoekgebieden 1, 2, 4, 6, 7 en IJ-ver-noord, wordt verondersteld dat de bovenstaande rekenmethode een overschatting is. Daarom is voor deze gebieden gekozen voor de minimale benodigde oppervlakte dat nodig is voor de totale energieopwekking in het gebied.

- Bij de kleine of risicovolle WOZ-zoekgebieden 3, 5+middenberm, 8, HK-noord west en HKzuidwest, wordt verondersteld dat bovenstaande rekenmethode leidt tot een onderschatting van het risico. Daarom is voor deze gebieden gekozen voor de totale oppervlakte van het WOZzoekgebied. De complexiteit van de ligging tussen verkeersbanen of dicht bij ankergebieden weegt in dit geval zwaarder dan de grootte van het daadwerkelijke windmolenpark.

- Voor de WOZ-zoekgebieden 4 en 5+middenberm wordt onderscheid gemaakt tussen maximale of beperkte invulling van het gebied. Dit betekent dat bij WOZ-zoekgebied 4, de wegingsfactor wordt verlaagd van 2 naar 1 als slechts $7 \mathrm{GW}$ wordt ingevuld en daarmee het zuidelijke risicovolle deel niet wordt ingevuld. Voor WOZ-zoekgebied 5 geldt dat de wegingsfactor wordt verlaagd van 1,75 naar 1 als de risicovolle middenberm niet wordt ingericht.

\subsection{Bronnen}

Voor het berekenen van de effecten op genoemde gebruiksfuncties zijn data nodig voor de startsituatie (2017) en de herijkte varianten voor de aanwijzing van windenergiegebieden (2040/2050) op de Noordzee. Data voor de startsituatie (2017) zijn gebaseerd op studies en data van BLIX, CBS, Ecorys, PBL, PWC, Ministeries en sectordata beheerd door Wageningen Economic Research (zie Roebeling et al., 2021). Data betreffen, met name, ruimtebeslag (c.q. locatie, vorm en oppervlakte) en intensiteit (c.q. inspanning, productie, kosten en waardes) van de sectoractiviteiten voor het NCP. 
Data voor de toekomstvarianten (2040/2050) zijn gebaseerd op Noordzeeoverleg gedefinieerd ruimtebeslag en intensiteit van de sectoractiviteiten voor de (6) herijkte varianten en

(11) subvarianten voor de aanwijzing van windenergiegebieden (2040/2050) op de Noordzee (aangeleverd begin oktober 2020), in combinatie met data van BLIX, PBL en PWC, Ministeries en sectordata beheerd door Wageningen Economic Research en overige informatie betrokken van relevante stakeholders (zie Roebeling et al., 2021) evenals nieuwe informatie die in oktober 2020 beschikbaar is gekomen (met name in relatie tot windenergie, visserij en scheepvaart; afkomstig van parallelle studies van BLIX (2020), Deetman et al. (2020) en RWS-ZD (2020)).

Voor deze verkenning vormden de volgende publicaties en gegevens de belangrijkste basis:

- De Wageningen Economic Research-publicaties De economische effecten van twee toekomstscenario's voor de Noordzee (Strietman et al., 2019) en De economische en ecologische effecten van inrichtingsvarianten voor de Noordzee tot 2040/2050 (Roebeling et al., 2021).

- De PBL-publicatie De toekomst van de Noordzee - De Noordzee in 2030 en 2050: een scenariostudie (Matthijsen et al., 2018) en het bijbehorende Achtergronden bij de toekomst van de Noordzee: onderliggende gegevens en aannames (Matthijsen et al., 2019).

- Sectordata over de Nederlandse visserij (beheerd door Wageningen Economic Research).

- De CBS-publicatie Economic description of the Dutch North Sea and Coast: 2005, 2010, 2014 (CBS, 2016), evenals recentere CBS (Statline-) gegevens uit de Nationale Rekeningen.

- De Ecorys-publicatie De Nederlandse Maritieme Cluster (Ecorys, 2018). De gegevens uit deze bron worden voornamelijk gebruikt om de indirecte effecten te bepalen en in sommige gevallen om de startsituatie te bepalen.

- De PROMOTION deliverable Synthesis of available studies on offshore meshed HVDC grids (PROMOTIoN, 2016), de Navigant studie Connecting offshore wind farms - a comparison of offshore electricity grid development models in Northwest Europe (Navigant, 2019), de PWC-publicatie De economische bijdrage van windenergie op zee (PWC, 2018) en de BLIX-publicatie Determination of the cost levels of wind farms (and their grid connections) in new offshore wind energy search areas (BLIX, 2020). 


\section{Definitie varianten en subvarianten}

De te vergelijken varianten voor de aanwijzing van windenergie-gebieden (2040/2050) op de Noordzee, zijn gebaseerd op acht wind-op-zee (WOZ-)zoekgebieden (Gebied 1 tot en met 8) en een drietal nog onbenutte delen van reeds aangewezen WOZ-zoekgebieden (IJmuiden-ver-noord; Hollandse Kust noordwest; Hollandse Kust zuidwest; zie figuur 3.1). De totale oppervlakte van deze WOZ-zoekgebieden is ruim $8.400 \mathrm{~km}^{2}$.

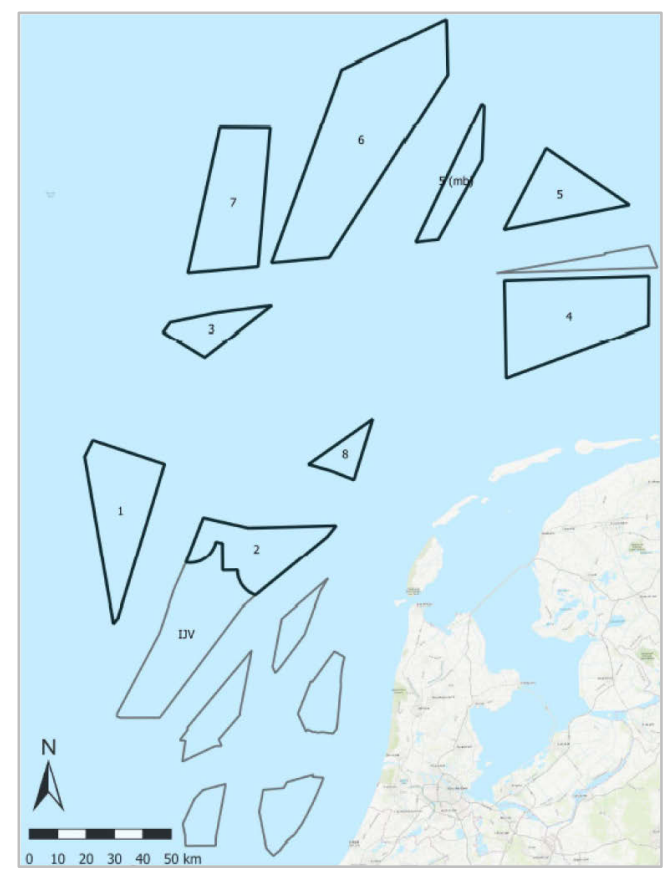

\begin{tabular}{lc} 
Woz-zoekgebied & Oppervlakte $\left(\mathrm{km}^{2}\right)$ \\
\hline Gebied 1 & 954 \\
\hline Gebied 2 & 740 \\
\hline IJ-ver-noord & 486 \\
\hline Gebied 3 & 276 \\
\hline Gebied 4 & 1.272 \\
\hline $5+$ middenberm & 917 \\
\hline Gebied 6 & 2.173 \\
\hline 7 staand & 1.000 \\
\hline Gebied 8 & 176 \\
\hline HK-noordwest & 189 \\
\hline HK-zuidwest & 232 \\
\hline Totaal & $\mathbf{8 . 4 1 7}$ \\
\hline
\end{tabular}

Figuur 3.1 Locatie en oppervlaktes van de wind-op-zee (WOZ) zoekgebieden 2040/2050 Bron: BLIX (2020); Deetman et al. (2020).

De doelstelling is dat de totale capaciteit groeit van 1,0 GW in 2017, naar 11,5 GW in 2030 tot $38,5 \mathrm{GW}$ in 2040/2050 (i.e. $+27 \mathrm{GW}$ ten opzichte van 2030). Een variant is een selectie van 4 tot 7 WOZ-zoek-gebieden, waarmee deze extra capaciteit van $27 \mathrm{GW}$ wordt gerealiseerd. Indien binnen een variant de WOZ-zoekgebieden optellen tot meer dan $27 \mathrm{GW}$, dan is er schuifruimte in de ruimtelijke invulling van de WOZ-zoekgebieden. Dit leidt tot 6 herijkte varianten ( $A$ tot en met $F$ ) en 11 subvarianten (zie tabel 3.1).

Tabel 3.1 Windmolenparken op zee per herijkte variant en subvariant in 2040/2050

\begin{tabular}{|c|c|c|c|c|c|c|c|c|c|c|c|c|c|c|c|c|c|c|}
\hline \multirow[t]{2}{*}{ Gebied } & \multirow{2}{*}{$\begin{array}{l}\text { Potentieel } \\
\text { (in GW) }\end{array}$} & \multirow[t]{2}{*}{ A } & $B$ & & C & & $\mathrm{D}$ & & $E$ & & \multirow[b]{2}{*}{$\begin{array}{l}\text { E-II } \\
\text { E-II-a }\end{array}$} & \multirow[b]{2}{*}{$E-I I-b$} & \multirow[b]{2}{*}{$\begin{array}{l}\text { E-III } \\
\text { E-III-a }\end{array}$} & \multirow[b]{2}{*}{$E-1 I I-b$} & \multirow[b]{2}{*}{\begin{tabular}{|c|} 
E-IV \\
E-IV-a
\end{tabular}} & \multirow[b]{2}{*}{$E-I V-b$} & \multirow{2}{*}{$\begin{array}{l}F \\
F-1\end{array}$} & \multirow[b]{2}{*}{ F-II } \\
\hline & & & $B-I$ & B-II & $C-1$ & C-II & D-I & D-II & $\begin{array}{c}E-1 \\
E-I-a\end{array}$ & $E-1-b$ & & & & & & & & \\
\hline Gebied 1 & 6 & 0 & 6 & 6 & 6 & 6 & 0 & 0 & 0 & 0 & 0 & 0 & 0 & 0 & 0 & 0 & 4 & 4 \\
\hline IJ-ver-noord & 2 & 0 & 2 & 2 & 2 & 2 & 2 & 2 & 2 & 2 & 2 & 2 & 2 & 2 & 2 & 2 & 2 & 2 \\
\hline Gebied 3 & 2 & 0 & 2 & 2 & 0 & 0 & 2 & 2 & 0 & 0 & 0 & 0 & 0 & 0 & 0 & 0 & 0 & 0 \\
\hline Gebied 4 & 10 & 7 & 5 & 0 & 9 & 0 & 10 & 0 & 7 & 0 & 10 & 0 & 10 & 0 & 10 & 0 & 5 & 0 \\
\hline 7 staand & 8 & 6 & 0 & 0 & 0 & 0 & 0 & 0 & 8 & 7 & 7 & 8 & 4 & 4 & 7 & 8 & 8 & 8 \\
\hline Gebied 8 & 2 & 0 & 2 & 2 & 0 & 0 & 0 & 0 & 0 & 0 & 0 & 0 & 0 & 0 & 0 & 0 & 0 & 0 \\
\hline HK-noord west & 2 & 0 & 0 & 0 & 0 & 0 & 0.7 & 0.7 & 0 & 0 & 0 & 0 & 0 & 0 & 0 & 0 & 0 & 0 \\
\hline HK-zuid west & 1.5 & 0 & 0 & 0 & 0 & 0 & 1.4 & 1.4 & 0 & 0 & 0 & 0 & 0 & 0 & 0 & 0 & 0 & 0 \\
\hline \multicolumn{2}{|c|}{ Totaal WOZ 2040/2050 } & 27 & 27 & 27 & 27 & 27 & 27 & 27 & 27 & 27 & 27 & 27 & 27 & 27 & 27 & 27 & 27 & 27 \\
\hline
\end{tabular}


Om tot een totaal van $27 \mathrm{GW}$ te komen is niet de volledige oppervlakte van de WOZ-zoekgebieden noodzakelijk. De invulling van de WOZ-zoekgebieden is gebaseerd op BLIX (2020), waarin voor ieder van de WOZ-zoekgebieden is aangegeven welke delen van het WOZ-zoekgebied (in zones van $2 \mathrm{GW}$ ) worden ingevuld (zie figuur 3.2). De totale oppervlakte van deze ingevulde WOZ-zoekgebieden (windmolenparken) is bijna $5.400 \mathrm{~km}^{2}$ en, dus, beduidend minder dan de totale oppervlakte van de WOZ-zoekgebieden (ruim $8.400 \mathrm{~km}^{2}$ ).

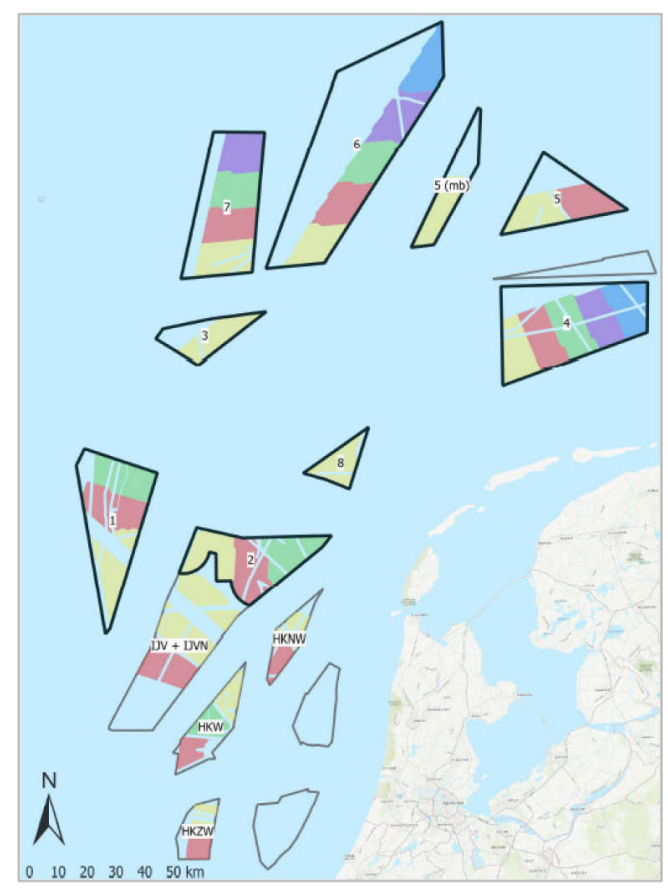

\begin{tabular}{lc} 
woz-zoekgebied & Oppervlakte $\left(\mathrm{km}^{2}\right)$ \\
Gebied 1 & 606 \\
\hline Gebied 2 & 604 \\
\hline IJ-ver-noord & 188 \\
\hline Gebied 3 & 192 \\
\hline Gebied 4 & 986 \\
\hline $5+$ middenberm & 583 \\
\hline Gebied 6 & 991 \\
\hline 7 staand & 803 \\
\hline Gebied 8 & 151 \\
\hline HK-noordwest & 124 \\
\hline HK-zuidwest & 133 \\
\hline Totaal & $\mathbf{5 . 3 6 1}$ \\
\hline
\end{tabular}

Figuur 3.2 Invulling en oppervlaktes van de wind-op-zee (WOZ) zoekgebieden 2040/2050 Bron: BLIX (2020).

Let wel: De huidige (2017; 1,0 GW) en Routekaart 2030 (+11,5 GW) windmolenparken zijn niet meegenomen in deze analyse (deze zijn gedefinieerd in de Structuurvisie Windenergie op Zee; EZK, 2018), zodat een duidelijke vergelijking tussen de varianten voor 2040/2050 (+27 GW) mogelijk is. Voor meer informatie over de huidige (2017) en Routekaart 2030 windmolenparken, zie EZK (2018). 


\section{$4 \quad$ Resultaten}

Resultaten zijn berekend voor de directe economische waardes per sector en per wind-op-zee (WOZ)zoekgebied (zie sectie 4.1), voor de directe economische waardes per sector, per WOZ-zoekgebied en per variant (zie sectie 4.2) en voor de directe en indirecte economische waardes per sector en per variant totaal voor de Noordzee (zie sectie 4.3) in termen van productiewaarde, toegevoegde waarde, werkgelegenheid en/of mitigatiekosten. 


\subsection{Per sector per WOZ-zoekgebied}

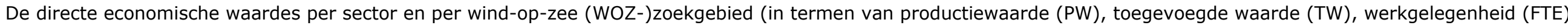

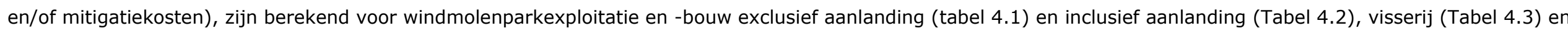
scheepvaart (tabel 4.4).

Tabel 4.1 Karakteristieken en waarden per windmolenpark ('offshore windfarm') exclusief aanlanding ('grid connection system')

\begin{tabular}{|c|c|c|c|c|c|c|c|c|c|c|c|}
\hline & 1 & 2 & IJ-ver-noord & 3 & 4 & $5+m b$ & 6 & 7 staand & 8 & HK-NW & HK-ZW \\
\hline Oppervlakte $\left(\mathrm{km}^{2}\right)$ & 606 & 604 & 188 & 192 & 986 & 583 & 991 & 803 & 151 & 124 & 133 \\
\hline Turbines: $\quad-\left(\# / \mathrm{km}^{2}\right)$ & 0,7 & 0,7 & 0,7 & 0,7 & 0,7 & 0,7 & 0,7 & 0,7 & 0,9 & 0,8 & 0,8 \\
\hline$-(\#)$ & 402 & 402 & 134 & 134 & 670 & 402 & 670 & 536 & 134 & 100 & 100 \\
\hline Levensduur (jaar) & 30 & 30 & 30 & 30 & 30 & 30 & 30 & 30 & 30 & 30 & 30 \\
\hline Capaciteit $\quad-\left(\mathrm{MW} / \mathrm{km}^{2}\right)$ & 10,0 & 10,0 & 10,7 & 10,5 & 10,2 & 10,3 & 10,1 & 10,0 & 13,3 & 12,1 & 11,3 \\
\hline$-(M W)$ & 6.030 & 6.030 & 2.010 & 2.010 & 10.050 & 6.030 & 10.050 & 8.040 & 2.010 & 1.500 & 1.500 \\
\hline Netto-opbrengst (GWh/jaar) & 26.188 & 25.875 & 8.567 & 8.950 & 43.325 & 27.113 & 44.032 & 34.451 & 8.594 & 6.637 & 6.408 \\
\hline \multicolumn{12}{|l|}{ EXPLOITATIE } \\
\hline Productiewaarde (mln. $€ / \mathrm{jr})$ & 1.087 & 1.074 & 356 & 371 & 1.798 & 1.125 & 1.827 & 1.430 & 357 & 275 & 266 \\
\hline Productiekosten (mln. $€ / \mathrm{jr}$ ) & 763 & 757 & 250 & 255 & 1.283 & 776 & 1.290 & 1.025 & 251 & 196 & 195 \\
\hline Toegevoegde waarde (mln. $€ / \mathrm{jr}$ ) & 324 & 317 & 105 & 116 & 515 & 350 & 538 & 405 & 105 & 79 & 71 \\
\hline FTE (fte) & 586 & 588 & 196 & 191 & 992 & 575 & 981 & 797 & 196 & 111 & 114 \\
\hline \multicolumn{12}{|l|}{ Bouw } \\
\hline Productiewaarde (mln. $€ / \mathrm{jr})$ & 752 & 746 & 246 & 252 & 1.264 & 764 & 1.270 & 1.009 & 247 & 193 & 192 \\
\hline Productiekosten (mln. $€ / \mathrm{jr}$ ) & 273 & 271 & 90 & 91 & 460 & 278 & 462 & 367 & 90 & 70 & 70 \\
\hline FTE (fte) & 644 & 647 & 215 & 210 & 1.091 & 632 & 1.079 & 876 & 215 & 122 & 126 \\
\hline \multicolumn{12}{|l|}{ INDICATOREN } \\
\hline Exploitatie TW/GW (mln. $€ / G W / j r)$ & 53,7 & 52,5 & 52,4 & 57,7 & 51,2 & 58,0 & 53,5 & 50,4 & 52,5 & 52,8 & 47,0 \\
\hline LCoE verschil ten opzichte van IJ-ver $(\%)^{1}$ & $-2,9 \%$ & $-2,5 \%$ & $-2,7 \%$ & $-4,9 \%$ & $-1,3 \%$ & $-4,7 \%$ & $-2,4 \%$ & $-0,9 \%$ & $-2,6 \%$ & $-1,5 \%$ & $1,6 \%$ \\
\hline
\end{tabular}

Note: ${ }^{1}$ Lifecycle cost of energy (LCOE) verschil ten opzichte van IJmuiden-ver uit BLIX (2020: p.73-74), waarbij negatieve percentages lagere kosten representeren. 


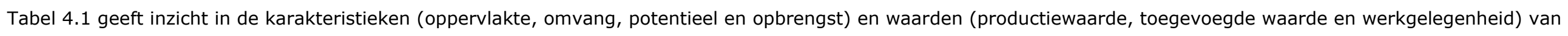

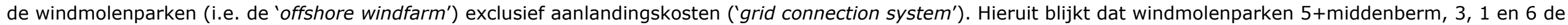

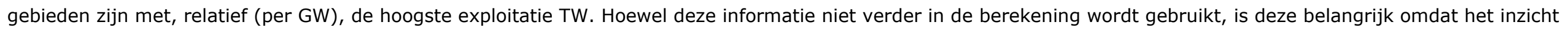

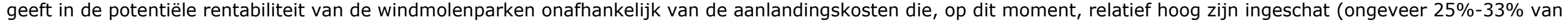

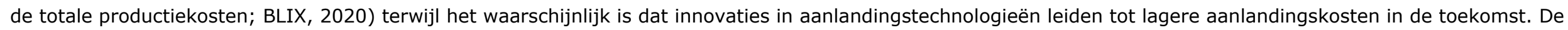
resultaten van NSE (2020) laten bijvoorbeeld zien dat er mogelijk kostenvoordelen zijn te behalen op systeemniveau door het offshore produceren van waterstof.

Tabel 4.2 Karakteristieken en waarden per windmolenpark ('offshore windfarm') inclusief aanlanding ('grid connection system')

\begin{tabular}{|c|c|c|c|c|c|c|c|c|c|c|c|}
\hline & 1 & 2 & IJ-ver-noord & 3 & 4 & $5+m b$ & 6 & 7 staand & 8 & HK-NW & HK-ZW \\
\hline Oppervlakte $\left(\mathrm{km}^{2}\right)$ & 606 & 604 & 188 & 192 & 986 & 583 & 991 & 803 & 151 & 124 & 133 \\
\hline Turbines: $\quad-\left(\# / \mathrm{km}^{2}\right)$ & 0,7 & 0,7 & 0,7 & 0,7 & 0,7 & 0,7 & 0,7 & 0,7 & 0,9 & 0,8 & 0,8 \\
\hline$-(\#)$ & 402 & 402 & 134 & 134 & 670 & 402 & 670 & 536 & 134 & 100 & 100 \\
\hline Levensduur (jaar) & 30 & 30 & 30 & 30 & 30 & 30 & 30 & 30 & 30 & 30 & 30 \\
\hline Capaciteit - $\left(\mathrm{MW} / \mathrm{km}^{2}\right)$ & 10,0 & 10,0 & 10,7 & 10,5 & 10,2 & 10,3 & 10,1 & 10,0 & 13,3 & 12,1 & 11,3 \\
\hline$-(M W)$ & 6.030 & 6.030 & 2.010 & 2.010 & 10.050 & 6.030 & 10.050 & 8.040 & 2.010 & 1.500 & 1.500 \\
\hline Netto-opbrengst (GWh/jaar) & 26.188 & 25.875 & 8.567 & 8.950 & 43.325 & 27.113 & 44.032 & 34.451 & 8.594 & 6.637 & 6.408 \\
\hline \multicolumn{12}{|l|}{ EXPLOITATIE } \\
\hline Productiewaarde (mln. $€ / \mathrm{jr})$ & 1.087 & 1.074 & 356 & 371 & 1.798 & 1.125 & 1.827 & 1.430 & 357 & 275 & 266 \\
\hline Productiekosten (mln. $€ / \mathrm{jr}$ ) & 1.020 & 986 & 340 & 349 & 1.662 & 1.035 & 1.786 & 1.438 & 331 & 227 & 228 \\
\hline Toegevoegde waarde (mln. $€ / \mathrm{jr}$ ) & 66 & 88 & 16 & 22 & 136 & 90 & 41 & -8 & 25 & 48 & 38 \\
\hline FTE (fte) & 757 & 740 & 257 & 253 & 1.242 & 742 & 1.313 & 1.081 & 250 & 126 & 131 \\
\hline \multicolumn{12}{|l|}{ Bouw } \\
\hline Productiewaarde (mln. $€ / \mathrm{jr}$ ) & 1.005 & 971 & 335 & 344 & 1.637 & 1.020 & 1.759 & 1.416 & 326 & 224 & 225 \\
\hline Productiekosten (mln. $€ / \mathrm{jr}$ ) & 366 & 353 & 122 & 125 & 595 & 371 & 640 & 515 & 119 & 81 & 82 \\
\hline FTE (fte) & 833 & 814 & 282 & 278 & 1.366 & 816 & 1.444 & 1.189 & 275 & 138 & 144 \\
\hline \multicolumn{12}{|l|}{ INDICATOREN } \\
\hline Exploitatie TW/GW (mln. €/GW/jr) & 11,0 & 14,5 & 7,8 & 11,1 & 13,6 & 14,9 & 4,1 & $-1,0$ & 12,6 & 32,2 & 25,1 \\
\hline LCoE verschil ten opzichte van IJ-ver (\%) & $-4,5 \%$ & $-6,6 \%$ & $-2,8 \%$ & $-4,4 \%$ & $-6,0 \%$ & $-6,4 \%$ & $-0,6 \%$ & $2,3 \%$ & $-5,5 \%$ & $-16,1 \%$ & $-12,7 \%$ \\
\hline
\end{tabular}

Note: ${ }^{1}$ Lifecycle cost of energy (LCOE) verschil ten opzichte van IJmuiden-ver uit BLIX (2020: p.71-72), waarbij negatieve percentages lagere kosten representeren. 


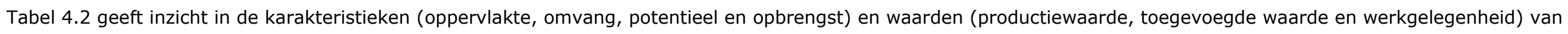

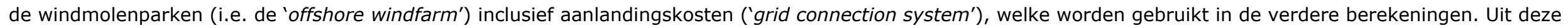
resultaten blijkt dat windmolenparken HK-noordwest, HK-zuidwest, 5+middenberm en 2 de gebieden zijn met, relatief (per GW), de hoogste exploitatie TW.

Tabel 4.3 Visserijwaarden (opportunity kosten) per windmolenpark (in m/n. $€ / j r$ )

\begin{tabular}{|c|c|c|c|c|c|c|c|c|c|c|c|}
\hline & 1 & 2 & IJ-ver-noord & 3 & 4 & $5+m b$ & 6 & 7 staand & 8 & HK-NW & HK-ZW \\
\hline Productiewaarde (mln. $€ / j \mathrm{r}$ ) & 1,17 & 0,84 & 0,38 & 0,28 & 0,36 & 0,84 & 0,41 & 0,43 & 0,02 & 0,18 & 0,30 \\
\hline Toegevoegde waarde ( $\mathrm{mln} . € / \mathrm{jr}$ ) & 0,56 & 0,36 & 0,17 & 0,12 & 0,15 & 0,39 & 0,19 & 0,19 & 0,01 & 0,08 & 0,14 \\
\hline FTE (fte) & 5,9 & 4,9 & 2,3 & 1,4 & 2,0 & 4,4 & 2,2 & 1,6 & 0,2 & 1,0 & 1,5 \\
\hline Visserij TW/GW (mln. €/GW/jr) & 0,09 & 0,07 & 0,08 & 0,06 & 0,02 & 0,07 & 0,02 & 0,02 & 0,01 & 0,11 & 0,10 \\
\hline Visserij FTE/GW (FTE/GW/jr) & 0,98 & 0,98 & 1,14 & 0,69 & 0,20 & 0,74 & 0,22 & 0,20 & 0,09 & 1,40 & 1,05 \\
\hline
\end{tabular}

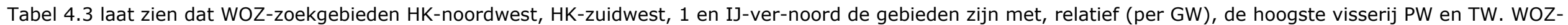
zoekgebieden HK-noordwest, IJ-ver-noord, HK-zuidwest, 1 en 2 zijn de gebieden met, relatief (per GW), de hoogste visserij werkgelegenheid.

Tabel 4.4 Scheepvaart mitigatiekosten (opportunity kosten) per windmolenpark (in m/n. €/jr)

\begin{tabular}{|c|c|c|c|c|c|c|c|c|c|c|c|}
\hline & 1 & 2 & IJ-ver-noord & 3 & 4 & $5+m b$ & 6 & 7 staand & 8 & HK-NW & HK-ZW \\
\hline Mitigatiekosten (mln. $€ / j \mathrm{r}$ ) & 11,6 & 23,1 & 5,4 & 10,6 & 37,8 & 30,7 & 19,0 & 17,3 & 16,9 & 18,1 & 22,2 \\
\hline Mitigatiekosten/GW (mln. $€ / G W / j r)$ & 1,9 & 4,6 & 2,7 & 5,3 & 1,9 & 5,1 & 1,9 & 2,9 & 8,4 & 25,9 & 15,9 \\
\hline
\end{tabular}

Tabel 4.4 laat zien dat WOZ-zoekgebieden HK-noordwest, HK-zuidwest en 8 de gebieden zijn met, relatief (per GW), de hoogste scheepvaart mitigatiekosten.

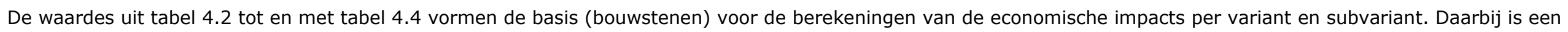
(sub)variant een selectie van 4 tot 7 WOZ-zoekgebieden, waarmee een capaciteit van 27 GW wordt gerealiseerd (zie Hoofdstuk 3). 


\subsection{Per sector per WOZ-zoekgebied per variant}

De directe economische waardes per sector, per wind-op-zee (WOZ-)zoekgebied en per variant (in termen van productiewaarde (PW), toegevoegde waarde (TW), werkgelegenheid (FTE) en/of mitigatiekosten), zijn berekend voor windmolenparkexploitatie (sectie 4.2.1), windmolenparkbouw (sectie 4.2.2), visserij (sectie 4.2.3) en scheepvaart (sectie 4.2.4).

Met betrekking tot windmolenparkexploitatie (sectie 4.2.1), laten de resultaten voor productiewaarde (PW) zien dat (tabel 4.5 en figuur 4.1):

- WOZ-zoekgebieden 5+middenberm, 3 en HK-noordwest zijn de zoekgebieden met, relatief (per GW), de hoogste exploitatie PW. Ofwel, deze hebben de hoogste yields (zie sectie 4.1).

- De exploitatie PW varieert weinig tussen de varianten, want alle varianten tellen op tot $27 \mathrm{GW}$ en variaties worden alleen verklaard door verschillen in yields tussen WOZ-zoekgebieden. Hoewel de verschillen in yields per WOZ-zoekgebied groot kunnen zijn, bestaan de varianten uit een mix van gebieden met relatieve hoge en lage yields.

- De exploitatie PW is het hoogst voor de varianten D-II, B-II, A en E-III-b, omdat deze alle (D-II) of meerdere (B-II) van bovengenoemde WOZ-zoekgebieden (met de hoogste exploitatie PW) bevatten.

Resultaten voor de windmolenparkexploitatie toegevoegde waarde (TW) laten zien dat (tabel 4.6 en figuur 4.2):

- WOZ-zoekgebieden HK-noordwest, HK-zuidwest, 5+middenberm en 2 zijn de zoekgebieden met, relatief (per GW), de hoogste exploitatie TW (zie sectie 4.1).

- De verschillen tussen de varianten worden bepaald door verschillen in yields, windfarm- en aanlandingskosten en operatie \& onderhoud kosten tussen WOZ-zoekgebieden.

- De exploitatie TW is positief voor alle varianten, want alle WOZ-zoekgebieden (behalve 7), hebben een positieve TW.

- De hoogste TW is verkregen voor de varianten D-I, C-I en B-I, omdat deze alle (D-I) of meerdere (C-I en B-I) van bovengenoemde WOZ-zoekgebieden (met hoogste exploitatie TW) bevatten.

Resultaten voor de windmolenparkexploitatie werkgelegenheid (FTE) laten zien dat (tabel 4.8 en figuur 4.23):

- De exploitatie werkgelegenheid varieert nauwelijks tussen de varianten, want alle varianten tellen op tot $27 \mathrm{GW}$ en variaties worden alleen verklaard door verschillen in yields tussen WOZzoekgebieden. Hoewel verschillen in yields per WOZ-zoekgebied groot kunnen zijn, bestaan de varianten uit een mix van gebieden met relatieve hoge en lage yields.

Samenvattend, de TW van windmolenparkexploitatie is het hoogst in de varianten D-I, C-I en B-I. De exploitatie TW in de corresponderende WOZ-zoekgebieden varieert tussen de 163 en $392 \mathrm{mln}$. $€ /$ jaar.

Met betrekking tot windmolenparkbouw (sectie 4.2.2), laten de resultaten voor productiewaarde (PW) zien dat (tabel 4.9 en figuur 4.4 ):

- WOZ-zoekgebieden 7, 6 en 3 zijn de gebieden met, relatief (per GW), de hoogste bouw PW (zie sectie 4.1). Hierbij komt de PW van windmolenparken bouw overeen met die van de productiekosten (minus operatie \& onderhoud) van windmolenparken exploitatie (zie sectie 2.2).

- De bouw PW varieert weinig tussen varianten, want alle varianten tellen op tot $27 \mathrm{GW}$ en variaties worden alleen verklaard door verschillen in windmolenpark- en aanlandingskosten tussen WOZzoekgebieden.

- De bouw PW is het hoogst voor de varianten E-IV-b, E-I-b en F-II, omdat deze WOZ-zoekgebieden 7 en 6 omvatten die ver van de kust afliggen (zie Hoofdstuk 3), een grote funderingsdiepte hebben (zie BLIX, 2020) en een grote omvang hebben (zie Hoofdstuk 3).

Resultaten voor de windmolenparkbouw toegevoegde waarde (TW) zijn vergelijkbaar met die van de windmolenparkbouw productiewaarde (PW), aangezien de bouw TW 36\% van de bouw PW vertegenwoordigt (zie sectie 2.2). Aldus laten de resultaten zien dat (tabel 4.9 en figuur 4.5):

- WOZ-zoekgebieden 7, 6 en 3 zijn de gebieden met, relatief (per GW), de hoogste bouw TW (zie sectie 4.1). 
- De bouw TW varieert weinig tussen varianten, want alle varianten tellen op tot $27 \mathrm{GW}$ en variaties worden alleen verklaard door verschillen in windmolenpark- en aanlandingskosten tussen WOZzoekgebieden.

- De bouw TW is het hoogst voor de varianten E-IV-b, E-I-b en F-II, omdat deze WOZ-zoekgebieden 7 en 6 omvatten die ver van de kust afliggen (zie Hoofdstuk 3), een grote funderingsdiepte hebben (zie BLIX, 2020) en een grote omvang hebben (zie Hoofdstuk 3).

Resultaten voor de windmolenparkbouw werkgelegenheid (FTE) laten zien dat (tabel 4.10 en figuur 4.6):

- WOZ-zoekgebieden 6, 7 en 4 zijn de gebieden met, relatief (per GW), de hoogste bouw werkgelegenheid (zie sectie 4.1).

- De bouw werkgelegenheid varieert weinig tussen varianten, want alle varianten tellen op tot $27 \mathrm{GW}$ en variaties worden alleen verklaard door verschillen in arbeidskosten voor windmolenpark- en aanlandingskosten tussen WOZ-zoekgebieden.

- De bouw werkgelegenheid is het hoogst voor de varianten E-IV-b, E-I-b, F-II en E-II-b, omdat deze WOZ-zoekgebieden 6 en 7 omvatten die ver van de kust afliggen (zie Hoofdstuk 3), een grote funderingsdiepte hebben (zie BLIX, 2020) en een grote omvang hebben (zie Hoofdstuk 3).

Samenvattend, de TW van windmolenparkbouw is het hoogst in de varianten E-IV-b, E-I-b en F-II. De bouw TW in de corresponderende WOZ-zoekgebieden varieert tussen de 579 en $609 \mathrm{mln}$. $€ /$ jaar.

Met betrekking tot visserij (sectie 4.2.3), corresponderen de resultaten met de opportunity cost van het in gebruik nemen van de WOZ-zoekgebieden. De resultaten voor productiewaarde (PW) laten zien dat (tabel 4.11 en figuur 4.7):

- WOZ-zoekgebieden HK-noordwest, HK-zuidwest, 1 en IJ-ver-noord zijn de gebieden met, relatief (per GW), de hoogste visserij PW (zie sectie 4.1).

- De PW van visserij in de WOZ-zoekgebieden is het hoogst in de varianten $B, C$ en D.

- De PW van visserij in de WOZ-zoekgebieden is het laagst in de varianten A, E-IV-a/b en E-II-a.

Resultaten voor de visserij toegevoegde waarde (TW) zijn vergelijkbaar met die van de visserij productiewaarde (PW), aangezien de visserij TW 45\% van de visserij PW vertegenwoordigt (zie sectie 2.2). Aldus laten de resultaten zien dat (tabel 4.12 en figuur 4.8):

- WOZ-zoekgebieden HK-noordwest, HK-zuidwest, 1 en IJ-ver-noord zijn de gebieden met, relatief (per GW), de hoogste visserij TW (zie sectie 4.1).

- De TW van visserij in de WOZ-zoekgebieden is het hoogst in de varianten $B, C$ en $D$.

- De TW van visserij in de WOZ-zoekgebieden is het laagst in de varianten A, E-IV-a/b en E-II-a. Resultaten voor de visserij werkgelegenheid (FTE) laten zien dat (tabel 4.13 en figuur 4.9):

- WOZ-zoekgebieden HK-noordwest, IJ-ver-noord, HK-zuidwest, 1 en 2 zijn de gebieden met, relatief (per GW), de hoogste visserij werkgelegenheid (zie sectie 4.1).

- De werkgelegenheid van visserij in de WOZ-zoekgebieden is het hoogst in de varianten $B, C$ en $D$.

- De werkgelegenheid van visserij in de WOZ-zoekgebieden is het laagst in de varianten A, E-IV-a/b, E-II-a en E-I-b.

Samenvattend, de gederfde toegevoegde waarde (TW) voor visserij is het hoogst in de in de varianten $B, C$ en $D$. De TW van de visserij in de corresponderende WOZ-zoekgebieden varieert tussen de 0,8 en $1,6 \mathrm{mln} . € /$ jaar.

Met betrekking tot scheepvaart (sectie 4.2.4), corresponderen de resultaten met de opportunity cost van het in gebruik nemen van de WOZ-zoekgebieden. De resultaten voor scheepvaart mitigatiekosten laten zien dat (tabel 4.14 en figuur 4.10):

- WOZ-zoekgebieden HK-noordwest, HK-zuidwest en 8 zijn de gebieden met, relatief (per GW), de hoogste scheepvaart mitigatiekosten (zie sectie 4.1).

- De scheepvaart mitigatiekosten in de WOZ-zoekgebieden zijn het hoogst in de varianten D-I, D-II en E-III-a.

- De scheepvaart mitigatiekosten in de WOZ-zoekgebieden zijn het laagst in de varianten E-I-b, A en E-IV-b/F-I/F-II.

Samenvattend, de scheepvaart mitigatiekosten zijn het hoogst in de in de varianten D-I, D-II en E-IIIa. De scheepvaart mitigatiekosten in de corresponderende WOZ-zoekgebieden varieert tussen de 75 en $147 \mathrm{mln}$. $€ /$ jaar. 


\subsubsection{Windmolenparkexploitatie}

Tabel 4.5 Directe productiewaarde (PW; in m/n. €/jaar) van windmolenparkexploitatie per WOZ-zoekgebied, voor varianten in $2040 / 2050$

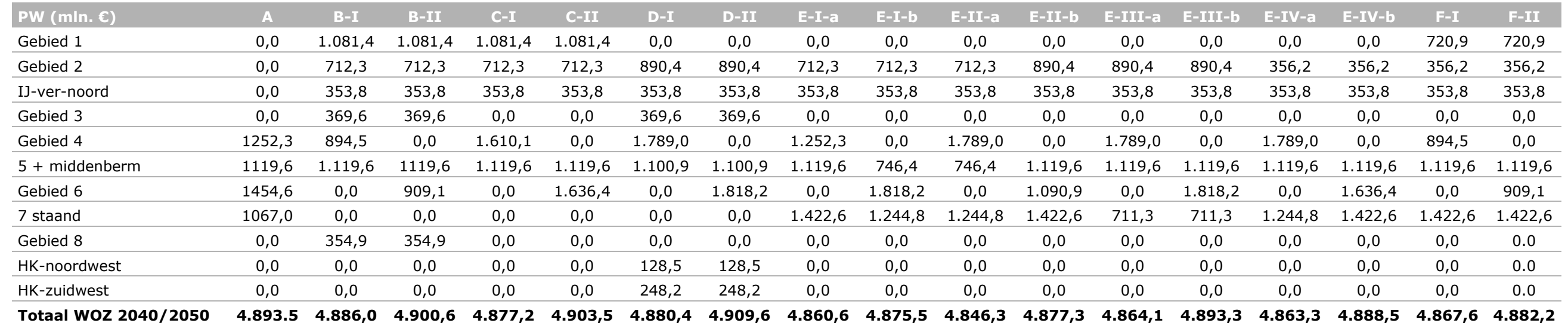

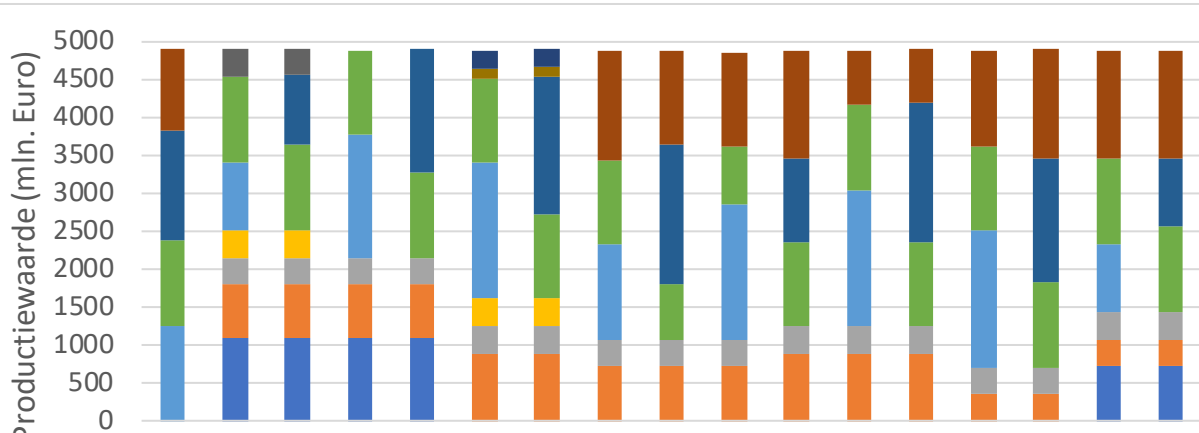

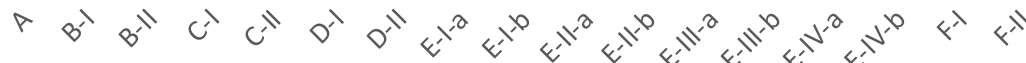
- Gebied 1
- Gebied 2
- IJ-ver-noord
- Gebied 3
- Gebied 4
$5+$ middenberm Gebied 6
- 7 staand
Gebied 8

- Gebieden 5+middenberm, 3 en HK-noordwest zijn de WOZ-zoekgebieden met, relatief (per GW), de hoogste exploitatie PW. I.e., deze hebben de hoogste yields (zie sectie 4.1).

- De exploitatie PW varieert weinig tussen varianten, want alle varianten tellen op tot $27 \mathrm{GW}$ en variaties worden alleen verklaard door verschillen in yields tussen WOZ-zoekgebieden. I.e., hoewe de verschillen in yields per WOZ-zoekgebied groot kunnen zijn, bestaan de varianten uit een mix van zoekgebieden met relatieve hoge en lage yields.

- De exploitatie PW is het hoogst voor de varianten D-II, B-II, A en E-III-b, omdat deze alle (D-II) of meerdere (B-II) van bovengenoemde WOZ-zoekgebieden bevatten.

Figuur 4.1 Directe productiewaarde (PW; in $\mathrm{mln}$. $€ /$ jaar) van windmolenparkexploitatie per WOZ-zoekgebied, voor varianten in 2040/2050 
Tabel 4.6 Directe toegevoegde waarde (TW; in mln. €/jaar) van windmolenparkexploitatie per WOZ-zoekgebied, voor varianten in 2040/2050

\begin{tabular}{|c|c|c|c|c|c|c|c|c|c|c|c|c|c|c|c|c|c|}
\hline TW (mln. c) & A & B-I & B-II & C-I & C-II & D-I & D-II & E-I-a & E-I-b & E-II-a & E-II-b & E-III-a & E-III-b & E-IV-a & E-IV-b & F-I & F-II \\
\hline Gebied 1 & 0,0 & 66,0 & 66,0 & 66,0 & 66,0 & 0,0 & 0,0 & 0,0 & 0,0 & 0,0 & 0,0 & 0,0 & 0,0 & 0,0 & 0,0 & 44,0 & 44.0 \\
\hline Gebied 2 & 0,0 & 58,2 & 58,2 & 58,2 & 58,2 & 72,7 & 72,7 & 58,2 & 58,2 & 58,2 & 72,7 & 72,7 & 72,7 & 29,1 & 29,1 & 29,1 & 29.1 \\
\hline IJ-ver-noord & 0,0 & 15,7 & 15,7 & 15,7 & 15,7 & 15,7 & 15,7 & 15,7 & 15,7 & 15,7 & 15,7 & 15,7 & 15,7 & 15,7 & 15,7 & 15,7 & 15.7 \\
\hline Gebied 3 & 0,0 & 22,2 & 22,2 & 0,0 & 0,0 & 22,2 & 22,2 & 0,0 & 0,0 & 0,0 & 0,0 & 0,0 & 0,0 & 0,0 & 0,0 & 0,0 & 0.0 \\
\hline Gebied 4 & 94,9 & 67,8 & 0,0 & 122,1 & 0,0 & 135,6 & 0,0 & 94,9 & 0,0 & 135,6 & 0,0 & 135,6 & 0,0 & 135,6 & 0,0 & 67,8 & 0.0 \\
\hline $5+$ middenberm & 89,3 & 89,3 & 89,3 & 89,3 & 89,3 & 87,8 & 87,8 & 89,3 & 59,5 & 59,5 & 89,3 & 89,3 & 89,3 & 89,3 & 89,3 & 89,3 & 89.3 \\
\hline Gebied 6 & 33,0 & 0,0 & 20,6 & 0,0 & 37,2 & 0,0 & 41,3 & 0,0 & 41,3 & 0,0 & 24,8 & 0,0 & 41,3 & 0,0 & 37,2 & 0,0 & 20.6 \\
\hline 7 staand & $-6,2$ & 0,0 & 0,0 & 0,0 & 0,0 & 0,0 & 0,0 & $-8,3$ & $-7,2$ & $-7,2$ & $-8,3$ & $-4,1$ & $-4,1$ & $-7,2$ & $-8,3$ & $-8,3$ & -8.3 \\
\hline Gebied 8 & 0,0 & 25,2 & 25,2 & 0,0 & 0,0 & 0,0 & 0,0 & 0,0 & 0,0 & 0,0 & 0,0 & 0,0 & 0,0 & 0,0 & 0,0 & 0,0 & 0.0 \\
\hline HK-noordwest & 0,0 & 0,0 & 0,0 & 0,0 & 0,0 & 22,5 & 22,5 & 0,0 & 0,0 & 0,0 & 0,0 & 0,0 & 0,0 & 0,0 & 0,0 & 0,0 & 0.0 \\
\hline HK-zuidwest & 0,0 & 0,0 & 0,0 & 0,0 & 0,0 & 35,2 & 35,2 & 0,0 & 0,0 & 0,0 & 0,0 & 0,0 & 0,0 & 0,0 & 0,0 & 0,0 & 0.0 \\
\hline Totaal WOZ 2040/2050 & 211.0 & 344,3 & 297,2 & 351,2 & 266,3 & 391,7 & 297,4 & 249,8 & 167,5 & 261,8 & 194,2 & 309,2 & 214,9 & 262,4 & 163,0 & 237,6 & 190,5 \\
\hline
\end{tabular}

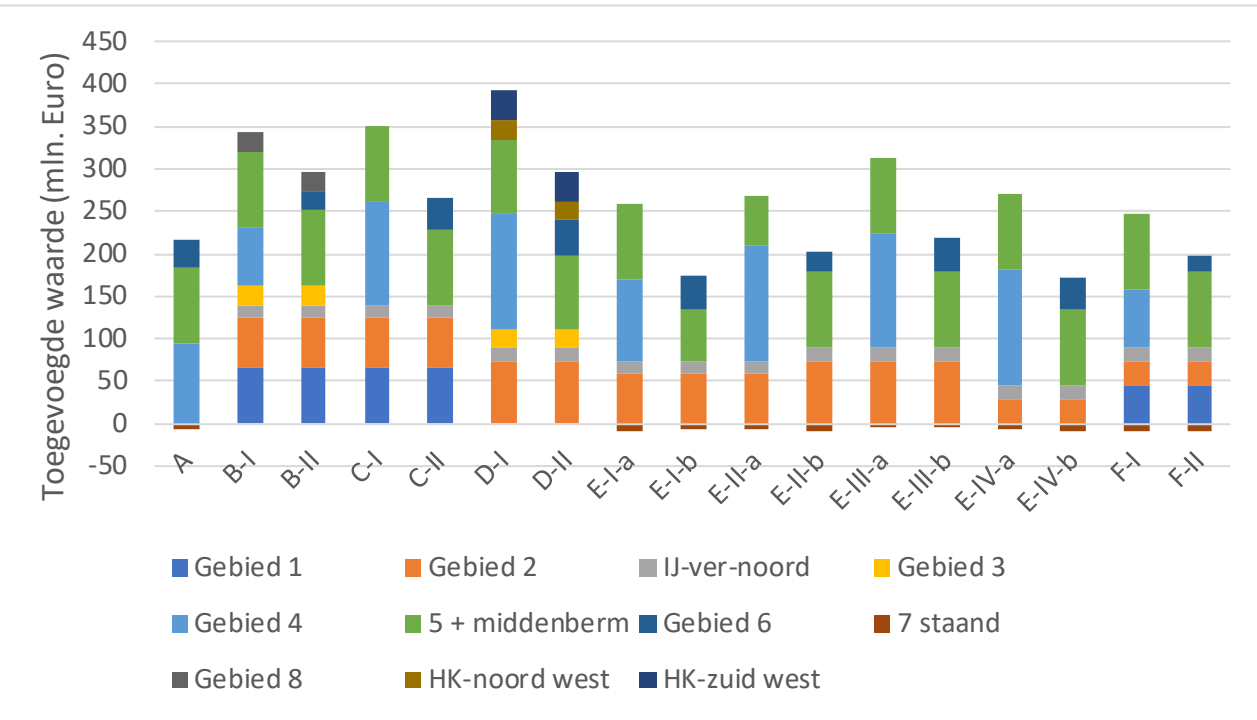

- Gebieden HK-noordwest, HK-zuidwest, 5+middenberm en 2 zijn de WOZ-zoekgebieden met, relatief (per GW), de hoogste exploitatie TW (zie sectie 4.1).

- De verschillen tussen varianten worden bepaald door verschillen in yields, windfarm- en aanlandingskosten en O\&M-kosten tussen WOZ-zoekgebieden.

- De exploitatie TW is positief voor alle varianten (want alle gebieden, behalve 7, hebben een positieve TW) en het hoogst voor de varianten D-I, C-I en B-I (omdat deze alle (D-I) of meerdere (C-I en B-I) van bovengenoemde WOZ-zoekgebieden bevatten).

Figuur 4.2 Directe toegevoegde waarde (TW; in mln. €/jaar) van windmolenparkexploitatie per WOZ-zoekgebied, voor varianten in $2040 / 2050$ 
Tabel 4.7 Directe werkgelegenheid (in fte/jaar) in windmolenparkexploitatie per WOZ-zoekgebied, voor varianten in 2040/2050

\begin{tabular}{|c|c|c|c|c|c|c|c|c|c|c|c|c|c|c|c|c|c|}
\hline FTE & A & B-I & B-II & C-I & C-II & D-I & D-II & E-I-a & E-I-b & E-II-a & E-II-b & E-III-a & E-III-b & E-IV-a & E-IV-b & F-I & F-II \\
\hline Gebied 1 & 0 & 753 & 753 & 753 & 753 & 0 & 0 & 0 & 0 & 0 & 0 & 0 & 0 & 0 & 0 & 502 & 502 \\
\hline Gebied 2 & 0 & 491 & 491 & 491 & 491 & 614 & 614 & 491 & 491 & 491 & 614 & 614 & 614 & 246 & 246 & 246 & 246 \\
\hline IJ-ver-noord & 0 & 256 & 256 & 256 & 256 & 256 & 256 & 256 & 256 & 256 & 256 & 256 & 256 & 256 & 256 & 256 & 256 \\
\hline Gebied 3 & 0 & 251 & 251 & 0 & 0 & 251 & 251 & 0 & 0 & 0 & 0 & 0 & 0 & 0 & 0 & 0 & 0 \\
\hline Gebied 4 & 865 & 618 & 0 & 1.112 & 0 & 1.236 & 0 & 865 & 0 & 1.236 & 0 & 1.236 & 0 & 1.236 & 0 & 618 & 0 \\
\hline $5+$ middenberm & 738 & 738 & 738 & 738 & 738 & 726 & 726 & 738 & 492 & 492 & 738 & 738 & 738 & 738 & 738 & 738 & 738 \\
\hline Gebied 6 & 1.045 & 0 & 653 & 0 & 1.176 & 0 & 1.307 & 0 & 1.307 & 0 & 784 & 0 & 1.307 & 0 & 1.176 & 0 & 653 \\
\hline 7 staand & 807 & 0 & 0 & 0 & 0 & 0 & 0 & 1.076 & 941 & 941 & 1.076 & 538 & 538 & 941 & 1.076 & 1.076 & 1.076 \\
\hline Gebied 8 & 0 & 248 & 248 & 0 & 0 & 0 & 0 & 0 & 0 & 0 & 0 & 0 & 0 & 0 & 0 & 0 & 0 \\
\hline HK-noordwest & 0 & 0 & 0 & 0 & 0 & 59 & 59 & 0 & 0 & 0 & 0 & 0 & 0 & 0 & 0 & 0 & 0 \\
\hline HK-zuidwest & 0 & 0 & 0 & 0 & 0 & 122 & 122 & 0 & 0 & 0 & 0 & 0 & 0 & 0 & 0 & 0 & 0 \\
\hline Totaal WOZ 2040/2050 & 3.455 & 3.356 & 3.391 & 3.350 & 3.414 & 3.263 & 3.334 & 3.426 & 3.487 & 3.416 & 3.467 & 3.381 & 3.452 & 3.416 & 3.491 & 3.435 & $\mathbf{3 . 4 7 0}$ \\
\hline
\end{tabular}

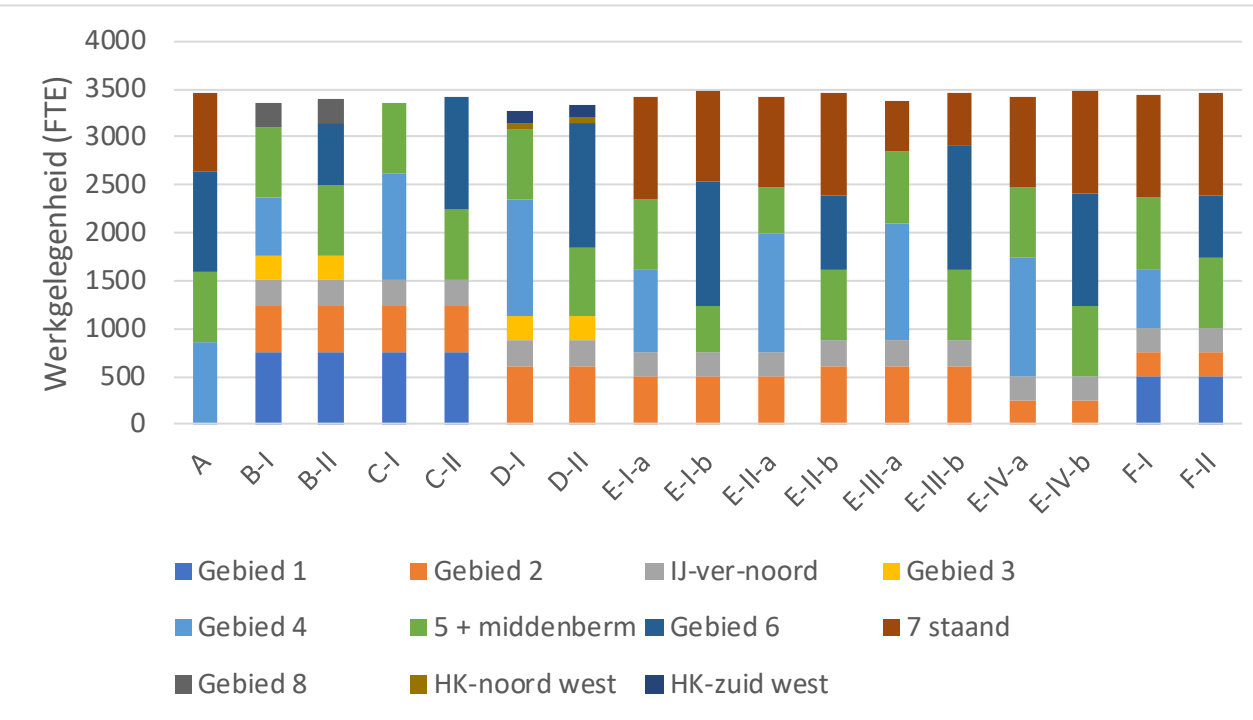

- De exploitatie werkgelegenheid varieert nauwelijks tussen varianten, want alle varianten tellen op tot $27 \mathrm{GW}$ en variaties worden alleen verklaard door verschillen in yields tussen WOZ-

zoekgebieden. Hoewel verschillen in yields per WOZ-zoekgebied groot kunnen zijn, bestaan de varianten uit een mix van gebieden met relatieve hoge en lage yields.

Figuur 4.3 Directe werkgelegenheid (in fte/jaar) in windmolenparkexploitatie per WOZ-zoekgebied, voor varianten in 2040/2050 


\subsubsection{Windmolenparkbouw}

Tabel 4.8 Directe productiewaarde ( $P$ W; in $\mathrm{mln}$. $€ /$ jaar) van windmolenparkbouw per WOZ-zoekgebied, voor varianten in $2040 / 2050$

\begin{tabular}{|c|c|c|c|c|c|c|c|c|c|c|c|c|c|c|c|c|c|}
\hline PW (mln. c) & A & B-I & B-II & C-I & C-II & D-I & D-II & E-I-a & E-I-b & E-II-a & E-II-b & E-III-a & E-III-b & E-IV-a & E-IV-b & F-I & F-II \\
\hline Gebied 1 & 0,0 & 360,1 & 360,1 & 360,1 & 360,1 & 0,0 & 0,0 & 0,0 & 0,0 & 0,0 & 0,0 & 0,0 & 0,0 & 0,0 & 0,0 & 240,0 & 240,0 \\
\hline Gebied 2 & 0,0 & 231,9 & 231,9 & 231,9 & 231,9 & 289,9 & 289,9 & 231,9 & 231,9 & 231,9 & 289,9 & 289,9 & 289,9 & 116,0 & 116,0 & 116,0 & 116,0 \\
\hline IJ-ver-noord & 0,0 & 119,9 & 119,9 & 119,9 & 119,9 & 119,9 & 119,9 & 119,9 & 119,9 & 119,9 & 119,9 & 119,9 & 119,9 & 119,9 & 119,9 & 119,9 & 119,9 \\
\hline Gebied 3 & 0,0 & 123,2 & 123,2 & 0,0 & 0,0 & 123,2 & 123,2 & 0,0 & 0,0 & 0,0 & 0,0 & 0,0 & 0,0 & 0,0 & 0,0 & 0,0 & 0.0 \\
\hline Gebied 4 & 410,4 & 293,2 & 0,0 & 527,7 & 0,0 & 586,3 & 0,0 & 410,4 & 0,0 & 586,3 & 0,0 & 586,3 & 0,0 & 586,3 & 0,0 & 293,2 & 0.0 \\
\hline $5+$ middenberm & 365,4 & 365,4 & 365,4 & 365,4 & 365,4 & 359,3 & 359,3 & 365,4 & 243,6 & 243,6 & 365,4 & 365,4 & 365,4 & 365,4 & 365,4 & 365,4 & 365,4 \\
\hline Gebied 6 & 504,1 & 0,0 & 315,1 & 0,0 & 567,1 & 0,0 & 630,1 & 0,0 & 630,1 & 0,0 & 378,1 & 0,0 & 630,1 & 0,0 & 567,1 & 0,0 & 315,1 \\
\hline 7 staand & 380,5 & 0,0 & 0,0 & 0,0 & 0,0 & 0,0 & 0,0 & 507,4 & 444,0 & 444,0 & 507,4 & 253,7 & 253,7 & 444,0 & 507,4 & 507,4 & 507,4 \\
\hline Gebied 8 & 0,0 & 116,9 & 116,9 & 0,0 & 0,0 & 0,0 & 0,0 & 0,0 & 0,0 & 0,0 & 0,0 & 0,0 & 0,0 & 0,0 & 0,0 & 0,0 & 0.0 \\
\hline HK-noordwest & 0,0 & 0,0 & 0,0 & 0,0 & 0,0 & 37,6 & 37,6 & 0,0 & 0,0 & 0,0 & 0,0 & 0,0 & 0,0 & 0,0 & 0,0 & 0,0 & 0.0 \\
\hline HK-zuidwest & 0,0 & 0,0 & 0,0 & 0,0 & 0,0 & 75,5 & 75,5 & 0,0 & 0,0 & 0,0 & 0,0 & 0,0 & 0,0 & 0,0 & 0,0 & 0,0 & 0.0 \\
\hline
\end{tabular}

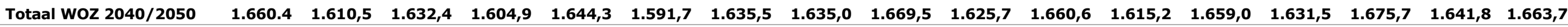

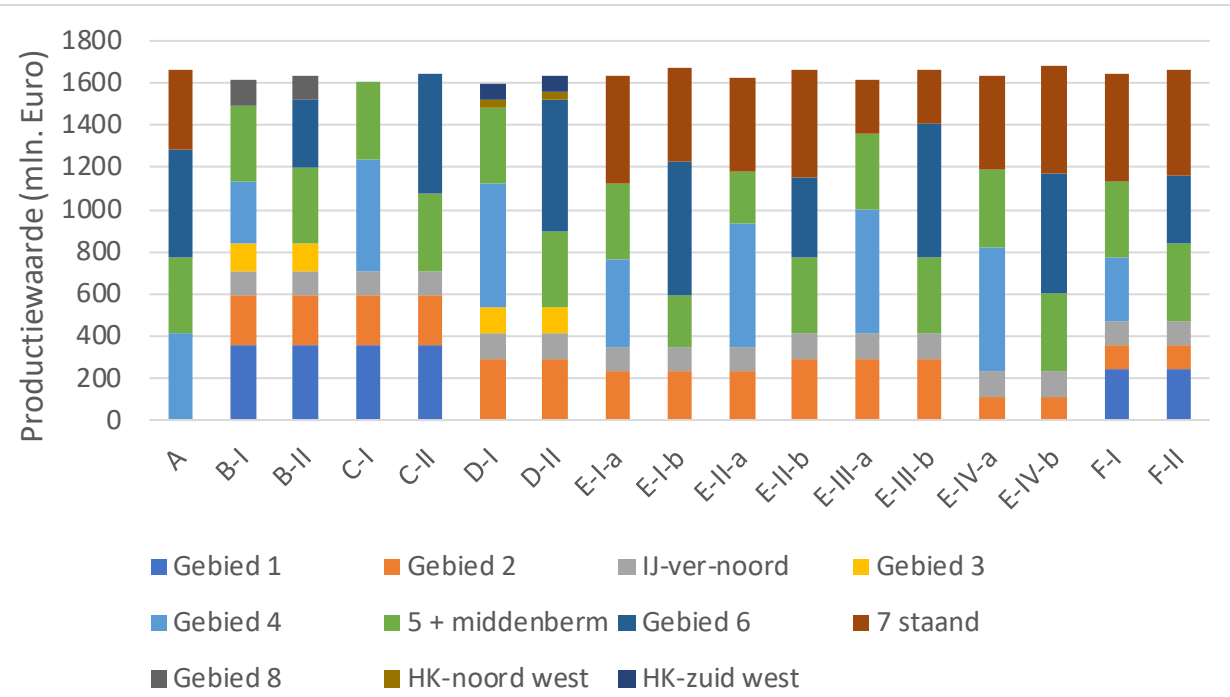

- Gebieden 7, 6 en 3 zijn de gebieden met, relatief (per GW), de hoogste bouw PW (zie sectie 4.1).

- De bouw PW varieert weinig tussen varianten, want alle varianten tellen op tot $27 \mathrm{GW}$ en variaties

worden alleen verklaard door verschillen in windfarm- en aanlandingskosten tussen WOZ-

zoekgebieden.

- De bouw PW is het hoogst voor de varianten E-IV-b, E-I-b en F-II, omdat deze Gebieden 7 en 6 omvatten die ver van de kust afliggen, een grote funderingsdiepte hebben (zie BLIX, 2020) en groot zijn.

Figuur 4.4 Directe productiewaarde (PW; in m/n. €/jaar) van windmolenparkbouw per WOZ-zoekgebied, voor varianten in 2040/2050 
Tabel 4.9 Directe toegevoegde waarde (TW; in $\mathrm{mln}$. $€ /$ jaar) van windmolenparkbouw per WOZ-zoekgebied, voor varianten in $2040 / 2050$

\begin{tabular}{|c|c|c|c|c|c|c|c|c|c|c|c|c|c|c|c|c|c|}
\hline TW (mln. $€)$ & A & B-I & B-II & C-I & C-II & D-I & D-II & E-I-a & E-I-b & E-II-a & E-II-b & E-III-a & E-III-b & E-IV-a & $E-I V-b$ & F-I & F-II \\
\hline Gebied 1 & 0,0 & 130,9 & 130,9 & 130,9 & 130,9 & 0,0 & 0,0 & 0,0 & 0,0 & 0,0 & 0,0 & 0,0 & 0,0 & 0,0 & 0,0 & 87,3 & 87,3 \\
\hline Gebied 2 & 0,0 & 84,3 & 84,3 & 84,3 & 84,3 & 105,4 & 105,4 & 84,3 & 84,3 & 84,3 & 105,4 & 105,4 & 105,4 & 42,2 & 42,2 & 42,2 & 42,2 \\
\hline IJ-ver-noord & 0,0 & 43,6 & 43,6 & 43,6 & 43,6 & 43,6 & 43,6 & 43,6 & 43,6 & 43,6 & 43,6 & 43,6 & 43,6 & 43,6 & 43,6 & 43,6 & 43,6 \\
\hline Gebied 3 & 0,0 & 44,8 & 44,8 & 0,0 & 0,0 & 44,8 & 44,8 & 0,0 & 0,0 & 0,0 & 0,0 & 0,0 & 0,0 & 0,0 & 0,0 & 0,0 & 0,0 \\
\hline Gebied 4 & 149,2 & 106,6 & 0,0 & 191,9 & 0,0 & 213,2 & 0,0 & 149,2 & 0,0 & 213,2 & 0,0 & 213,2 & 0,0 & 213,2 & 0,0 & 106,6 & 0,0 \\
\hline $5+$ middenberm & 132,9 & 132,9 & 132,9 & 132,9 & 132,9 & 130,6 & 130,6 & 132,9 & 88,6 & 88,6 & 132,9 & 132,9 & 132,9 & 132,9 & 132,9 & 132,9 & 132,9 \\
\hline Gebied 6 & 183,3 & 0,0 & 114,6 & 0,0 & 206,2 & 0,0 & 229,1 & 0,0 & 229,1 & 0,0 & 137,5 & 0,0 & 229,1 & 0,0 & 206,2 & 0,0 & 114,6 \\
\hline 7 staand & 138,4 & 0,0 & 0,0 & 0,0 & 0,0 & 0,0 & 0,0 & 184,5 & 161,4 & 161,4 & 184,5 & 92,3 & 92,3 & 161,4 & 184,5 & 184,5 & 184,5 \\
\hline Gebied 8 & 0,0 & 42,5 & 42,5 & 0,0 & 0,0 & 0,0 & 0,0 & 0,0 & 0,0 & 0,0 & 0,0 & 0,0 & 0,0 & 0,0 & 0,0 & 0,0 & 0,0 \\
\hline HK-noordwest & 0,0 & 0,0 & 0,0 & 0,0 & 0,0 & 13,7 & 13,7 & 0,0 & 0,0 & 0,0 & 0,0 & 0,0 & 0,0 & 0,0 & 0,0 & 0,0 & 0,0 \\
\hline HK-zuidwest & 0,0 & 0,0 & 0,0 & 0,0 & 0,0 & 27,5 & 27,5 & 0,0 & 0,0 & 0,0 & 0,0 & 0,0 & 0,0 & 0,0 & 0,0 & 0,0 & 0,0 \\
\hline Totaal WOZ 2040 & 603,8 & 585,6 & 593,6 & 583,6 & 597,9 & 578,8 & 594,7 & 594,5 & 607,1 & 591,2 & 603,9 & 587,3 & 603,3 & 593,3 & 609,3 & 597,0 & 605,0 \\
\hline
\end{tabular}

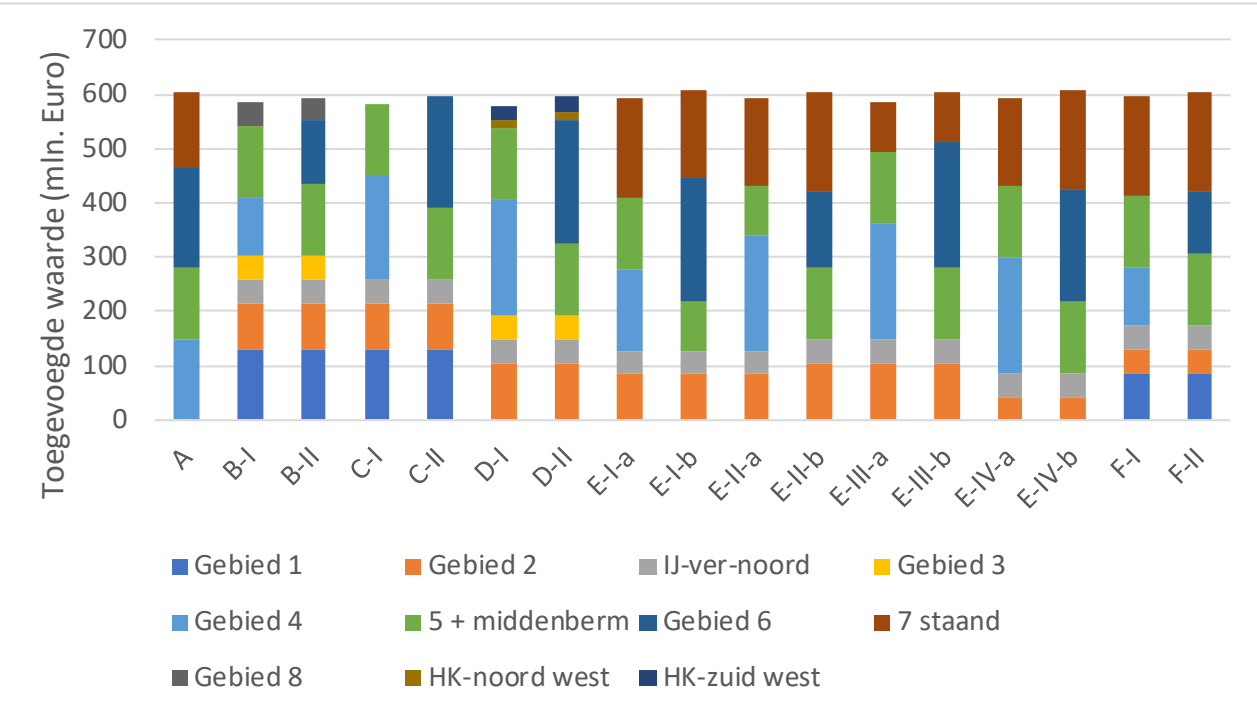

- De bouw TW vertegenwoordigt 36\% van de bouw PW en, dus, zelfde opmerkingen als bij bouw PW (zie vorige pagina).

Figuur 4.5 Directe toegevoegde waarde (TW; in m/n. $€ /$ jaar) van windmolenparkbouw per WOZ-zoekgebied, voor varianten in $2040 / 2050$ 
Tabel 4.10 Directe werkgelegenheid (in fte/jaar) in windmolenparkbouw per WOZ-zoekgebied, voor varianten in 2040/2050

\begin{tabular}{|c|c|c|c|c|c|c|c|c|c|c|c|c|c|c|c|c|c|}
\hline FTE & A & $B-I$ & B-II & C-I & C-II & D-I & D-II & E-I-a & E-I-b & E-II-a & E-II-b & E-III-a & E-III-b & E-IV-a & $E-I V-b$ & F-I & F-II \\
\hline Gebied 1 & 0 & 829 & 829 & 829 & 829 & 0 & 0 & 0 & 0 & 0 & 0 & 0 & 0 & 0 & 0 & 552 & 552 \\
\hline Gebied 2 & 0 & 540 & 540 & 540 & 540 & 675 & 675 & 540 & 540 & 540 & 675 & 675 & 675 & 270 & 270 & 270 & 270 \\
\hline IJ-ver-noord & 0 & 281 & 281 & 281 & 281 & 281 & 281 & 281 & 281 & 281 & 281 & 281 & 281 & 281 & 281 & 281 & 281 \\
\hline Gebied 3 & 0 & 276 & 276 & 0 & 0 & 276 & 276 & 0 & 0 & 0 & 0 & 0 & 0 & 0 & 0 & 0 & 0 \\
\hline Gebied 4 & 951 & 680 & 0 & 1.223 & 0 & 1.359 & 0 & 951 & 0 & 1.359 & 0 & 1.359 & 0 & 1.359 & 0 & 680 & 0 \\
\hline $5+$ middenberm & 812 & 812 & 812 & 812 & 812 & 798 & 798 & 812 & 541 & 541 & 812 & 812 & 812 & 812 & 812 & 812 & 812 \\
\hline Gebied 6 & 1.150 & 0 & 719 & 0 & 1.294 & 0 & 1.437 & 0 & 1.437 & 0 & 862 & 0 & 1.437 & 0 & 1.294 & 0 & 719 \\
\hline 7 staand & 888 & 0 & 0 & 0 & 0 & 0 & 0 & 1.183 & 1.035 & 1.035 & 1.183 & 592 & 592 & 1.035 & 1.183 & 1.183 & 1.183 \\
\hline Gebied 8 & 0 & 273 & 273 & 0 & 0 & 0 & 0 & 0 & 0 & 0 & 0 & 0 & 0 & 0 & 0 & 0 & 0 \\
\hline HK-noordwest & 0 & 0 & 0 & 0 & 0 & 65 & 65 & 0 & 0 & 0 & 0 & 0 & 0 & 0 & 0 & 0 & 0 \\
\hline HK-zuidwest & 0 & 0 & 0 & 0 & 0 & 134 & 134 & 0 & 0 & 0 & 0 & 0 & 0 & 0 & 0 & 0 & 0 \\
\hline Totaal WOZ 2040/2050 & 3.801 & 3.691 & 3.730 & 3.685 & 3.755 & 3.589 & 3.668 & 3.768 & 3.835 & 3.757 & 3.814 & 3.719 & 3.797 & 3.758 & 3.840 & 3.778 & 3.818 \\
\hline
\end{tabular}

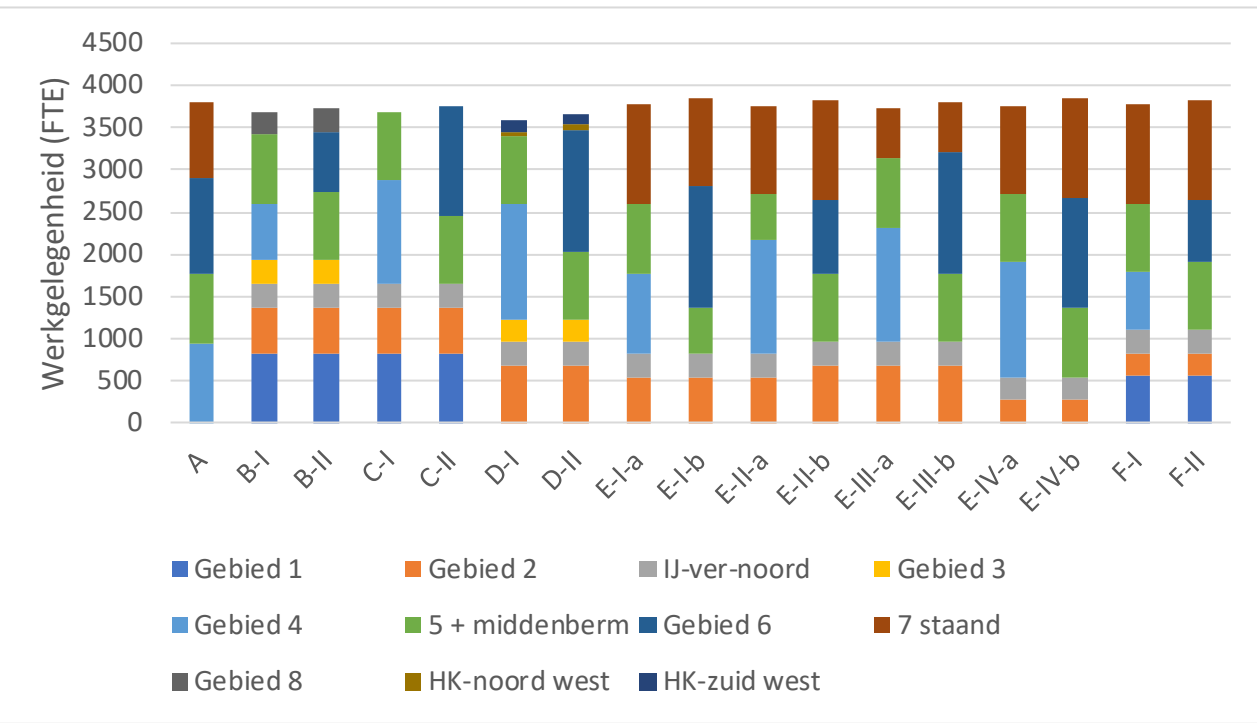

- Gebieden 6, 7 en 4 zijn de gebieden met, relatief (per GW), de hoogste bouw werkgelegenheid (zie sectie 4.1).

- De bouw werkgelegenheid varieert weinig tussen varianten, want alle varianten tellen op tot $27 \mathrm{GW}$ en variaties worden alleen verklaard door verschillen in arbeidskosten voor windfarm- en aanlandingskosten tussen WOZ-zoekgebieden.

- De bouw werkgelegenheid is het hoogst voor de varianten E-IV-b, E-I-b, F-II en E-II-b, omdat deze Gebieden 6 en 7 omvatten die ver van de kust afliggen, een grote funderings-diepte hebben (zie BLIX, 2020) en groot zijn.

Figuur 4.6 Directe werkgelegenheid (in fte/jaar) in windmolenparkbouw per WOZ-zoekgebied, voor varianten in 2040/2050 


\subsubsection{Visserij}

Tabel 4.11 Directe productiewaarde ( $P W$; in m/n. $€ / j a a r)$ van visserij per WOZ-zoekgebied, voor varianten in 2040/2050

\begin{tabular}{|c|c|c|c|c|c|c|c|c|c|c|c|c|c|c|c|c|c|}
\hline PW (mln. $€)$ & A & B-I & B-II & C-I & C-II & D-I & D-II & E-I-a & $E-I-b$ & E-II-a & E-II-b & E-III-a & E-III-b & E-IV-a & $E-I V-b$ & $F-I$ & F-II \\
\hline Gebied 1 & 0,00 & 1,17 & 1,17 & 1,17 & 1,17 & 0,00 & 0,00 & 0,00 & 0,00 & 0,00 & 0,00 & 0,00 & 0,00 & 0,00 & 0,00 & 0,78 & 0,78 \\
\hline Gebied 2 & 0,00 & 0,67 & 0,67 & 0,67 & 0,67 & 0,84 & 0,84 & 0,67 & 0,67 & 0,67 & 0,84 & 0,84 & 0,84 & 0,34 & 0,34 & 0,34 & 0,34 \\
\hline IJ-ver-noord & 0,00 & 0,38 & 0,38 & 0,38 & 0,38 & 0,38 & 0,38 & 0,38 & 0,38 & 0,38 & 0,38 & 0,38 & 0,38 & 0,38 & 0,38 & 0,38 & 0,38 \\
\hline Gebied 3 & 0,00 & 0,28 & 0,28 & 0,00 & 0,00 & 0,28 & 0,28 & 0,00 & 0,00 & 0,00 & 0,00 & 0,00 & 0,00 & 0,00 & 0,00 & 0,00 & 0,00 \\
\hline Gebied 4 & 0,25 & 0,18 & 0,00 & 0,33 & 0,00 & 0,36 & 0,00 & 0,25 & 0,00 & 0,36 & 0,00 & 0,36 & 0,00 & 0,36 & 0,00 & 0,18 & 0,00 \\
\hline $5+$ middenberm & 0,84 & 0,84 & 0,84 & 0,84 & 0,84 & 0,82 & 0,82 & 0,84 & 0,56 & 0,56 & 0,84 & 0,84 & 0,84 & 0,84 & 0,84 & 0,84 & 0,84 \\
\hline Gebied 6 & 0,33 & 0,00 & 0,20 & 0,00 & 0,37 & 0,00 & 0,41 & 0,00 & 0,41 & 0,00 & 0,25 & 0,00 & 0,41 & 0,00 & 0,37 & 0,00 & 0,20 \\
\hline 7 staand & 0,32 & 0,00 & 0,00 & 0,00 & 0,00 & 0,00 & 0,00 & 0,43 & 0,38 & 0,38 & 0,43 & 0,21 & 0,21 & 0,38 & 0,43 & 0,43 & 0,43 \\
\hline Gebied 8 & 0,00 & 0,02 & 0,02 & 0,00 & 0,00 & 0,00 & 0,00 & 0,00 & 0,00 & 0,00 & 0,00 & 0,00 & 0,00 & 0,00 & 0,00 & 0,00 & 0,00 \\
\hline HK-noordwest & 0,00 & 0,00 & 0,00 & 0,00 & 0,00 & 0,18 & 0,18 & 0,00 & 0,00 & 0,00 & 0,00 & 0,00 & 0,00 & 0,00 & 0,00 & 0,00 & 0,00 \\
\hline HK-zuidwest & 0,00 & 0,00 & 0,00 & 0,00 & 0,00 & 0,30 & 0,30 & 0,00 & 0,00 & 0,00 & 0,00 & 0,00 & 0,00 & 0,00 & 0,00 & 0,00 & 0,00 \\
\hline Totaal WOZ 2040/2050 & 1,74 & 3,55 & 3,57 & 3,39 & 3,43 & 3,16 & 3,21 & 2,57 & 2,39 & 2,35 & 2,73 & 2,63 & 2,68 & 2,29 & 2,35 & 2,95 & 2,97 \\
\hline
\end{tabular}

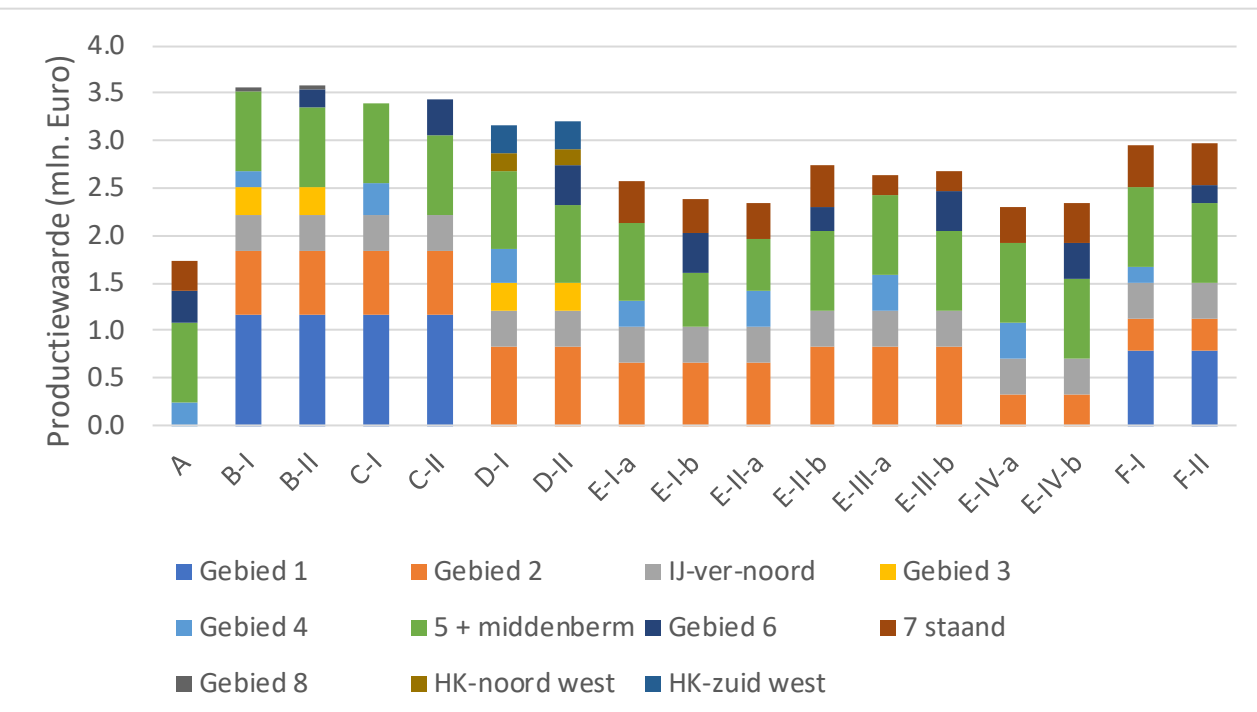

- De hier gepresenteerde PW is de opportunity cost van het in gebruik nemen van deze gebieden voor het exploiteren van WOZ.

- Gebieden HK-noordwest, HK-zuidwest, 1 en IJ-ver-noord zijn de gebieden met, relatief (per GW), de hoogste visserij PW (zie sectie 4.1)

- De PW van visserij in de WOZ-zoekgebieden is het hoogst in de varianten $B, C$ en $D$.

- De PW van visserij in de WOZ-zoekgebieden is het laagst in de varianten A, E-IV-a/b, E-II-a en E-I-b.

Figuur 4.7 Directe productiewaarde (PW; in $\mathrm{mln}$. $€ /$ jaar) van visserij per WOZ-zoekgebied, voor varianten in 2040/2050 
Tabel 4.12 Directe toegevoegde waarde (TW; in m/n. €/jaar) van visserij per WOZ-zoekgebied, voor varianten in 2040/2050

\begin{tabular}{|c|c|c|c|c|c|c|c|c|c|c|c|c|c|c|c|c|c|}
\hline TW (mln. c) & A & B-I & B-II & C-I & C-II & D-I & D-II & E-I-a & E-I-b & E-II-a & E-II-b & E-III-a & E-III-b & E-IV-a & E-IV-b & F-I & F-II \\
\hline Gebied 1 & 0,00 & 0,56 & 0,56 & 0,56 & 0,56 & 0,00 & 0,00 & 0,00 & 0,00 & 0,00 & 0,00 & 0,00 & 0,00 & 0,00 & 0,00 & 0,38 & 0,38 \\
\hline Gebied 2 & 0,00 & 0,29 & 0,29 & 0,29 & 0,29 & 0,36 & 0,36 & 0,29 & 0,29 & 0,29 & 0,36 & 0,36 & 0,36 & 0,14 & 0,14 & 0,14 & 0,14 \\
\hline IJ-ver-noord & 0,00 & 0,17 & 0,17 & 0,17 & 0,17 & 0,17 & 0,17 & 0,17 & 0,17 & 0,17 & 0,17 & 0,17 & 0,17 & 0,17 & 0,17 & 0,17 & 0,17 \\
\hline Gebied 3 & 0,00 & 0,12 & 0,12 & 0,00 & 0,00 & 0,12 & 0,12 & 0,00 & 0,00 & 0,00 & 0,00 & 0,00 & 0,00 & 0,00 & 0,00 & 0,00 & 0,00 \\
\hline Gebied 4 & 0,11 & 0,08 & 0,00 & 0,14 & 0,00 & 0,15 & 0,00 & 0,11 & 0,00 & 0,15 & 0,00 & 0,15 & 0,00 & 0,15 & 0,00 & 0,08 & 0,00 \\
\hline $5+$ middenberm & 0,39 & 0,39 & 0,39 & 0,39 & 0,39 & 0,39 & 0,39 & 0,39 & 0,26 & 0,26 & 0,39 & 0,39 & 0,39 & 0,39 & 0,39 & 0,39 & 0,39 \\
\hline Gebied 6 & 0,15 & 0,00 & 0,10 & 0,00 & 0,17 & 0,00 & 0,19 & 0,00 & 0,19 & 0,00 & 0,12 & 0,00 & 0,19 & 0,00 & 0,17 & 0,00 & 0,10 \\
\hline 7 staand & 0,14 & 0,00 & 0,00 & 0,00 & 0,00 & 0,00 & 0,00 & 0,19 & 0,17 & 0,17 & 0,19 & 0,10 & 0,10 & 0,17 & 0,19 & 0,19 & 0,19 \\
\hline Gebied 8 & 0,00 & 0,01 & 0,01 & 0,00 & 0,00 & 0,00 & 0,00 & 0,00 & 0,00 & 0,00 & 0,00 & 0,00 & 0,00 & 0,00 & 0,00 & 0,00 & 0,00 \\
\hline HK-noordwest & 0,00 & 0,00 & 0,00 & 0,00 & 0,00 & 0,08 & 0,08 & 0,00 & 0,00 & 0,00 & 0,00 & 0,00 & 0,00 & 0,00 & 0,00 & 0,00 & 0,00 \\
\hline HK-zuidwest & 0,00 & 0,00 & 0,00 & 0,00 & 0,00 & 0,14 & 0,14 & 0,00 & 0,00 & 0,00 & 0,00 & 0,00 & 0,00 & 0,00 & 0,00 & 0,00 & 0,00 \\
\hline Totaal WOZ $2040 / 2050$ & 0,80 & 1,62 & 1,64 & 1,55 & 1,59 & 1,40 & 1,44 & 1,15 & 1,08 & 1,04 & 1,23 & 1,17 & 1,21 & 1,03 & 1,07 & 1,35 & 1,37 \\
\hline
\end{tabular}

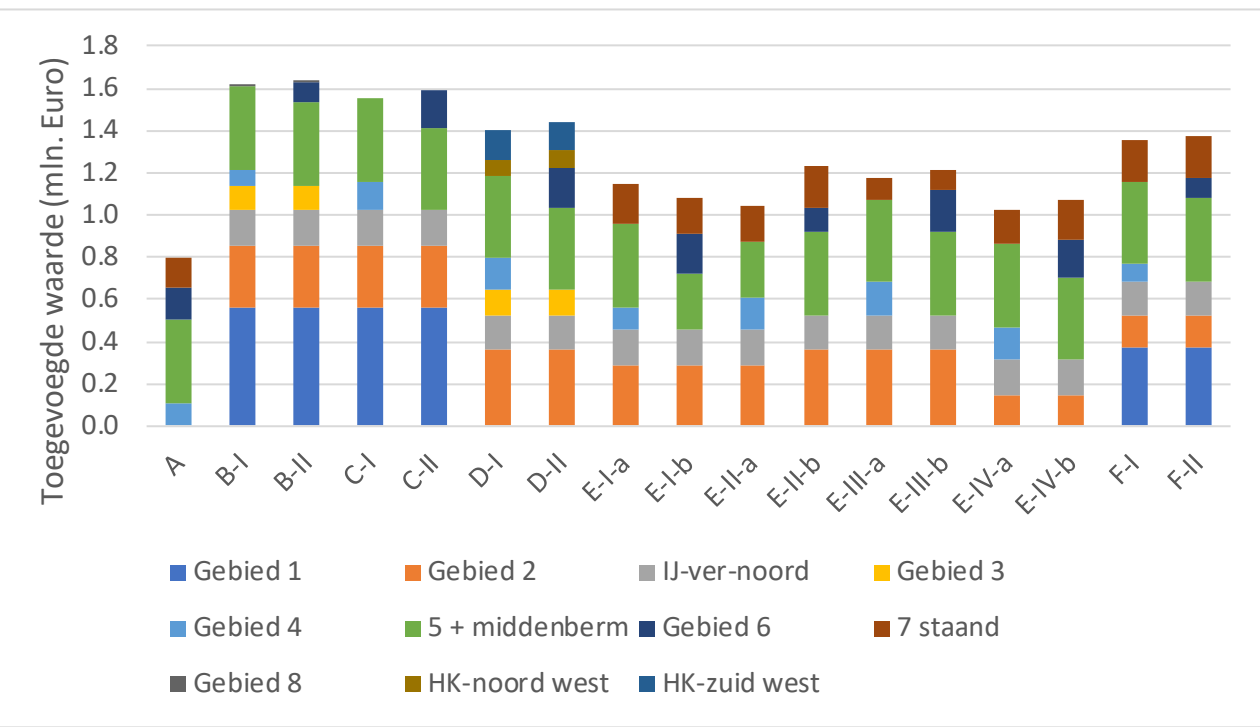

- De hier gepresenteerde TW is de opportunity cost van het in gebruik nemen van deze gebieden voor het exploiteren van WOZ.

- De visserij TW vertegenwoordigt 45\% van de visserij PW en, dus, zelfde opmerkingen als bij visserij PW (zie vorige pagina).

Figuur 4.8 Directe toegevoegde waarde (TW; in m/n. $€ /$ jaar) van visserij per WOZ-zoekgebied, voor varianten in 2040/2050 
Tabel 4.13 Directe werkgelegenheid (in fte/jaar) in visserij per WOZ-zoekgebied, voor varianten in 2040/2050

\begin{tabular}{|c|c|c|c|c|c|c|c|c|c|c|c|c|c|c|c|c|c|}
\hline FTE & A & B-I & B-II & C-I & C-II & D-I & D-II & E-I-a & E-I-b & E-II-a & E-II-b & E-III-a & E-III-b & $E-I V-a$ & $E-I V-b$ & F-I & F-II \\
\hline Gebied 1 & 0,0 & 5,9 & 5,9 & 5,9 & 5,9 & 0,0 & 0,0 & 0,0 & 0,0 & 0,0 & 0,0 & 0,0 & 0,0 & 0,0 & 0,0 & 3,9 & 3,9 \\
\hline Gebied 2 & 0,0 & 3,9 & 3,9 & 3,9 & 3,9 & 4,9 & 4,9 & 3,9 & 3,9 & 3,9 & 4,9 & 4,9 & 4,9 & 2,0 & 2,0 & 2,0 & 2,0 \\
\hline IJ-ver-noord & 0,0 & 2,3 & 2,3 & 2,3 & 2,3 & 2,3 & 2,3 & 2,3 & 2,3 & 2,3 & 2,3 & 2,3 & 2,3 & 2,3 & 2,3 & 2,3 & 2,3 \\
\hline Gebied 3 & 0,0 & 1,4 & 1,4 & 0,0 & 0,0 & 1,4 & 1,4 & 0,0 & 0,0 & 0,0 & 0,0 & 0,0 & 0,0 & 0,0 & 0,0 & 0,0 & 0,0 \\
\hline Gebied 4 & 1,4 & 1,0 & 0,0 & 1,8 & 0,0 & 2,0 & 0,0 & 1,4 & 0,0 & 2,0 & 0,0 & 2,0 & 0,0 & 2,0 & 0,0 & 1,0 & 0,0 \\
\hline $5+$ middenberm & 4,4 & 4,4 & 4,4 & 4,4 & 4,4 & 4,4 & 4,4 & 4,4 & 3,0 & 3,0 & 4,4 & 4,4 & 4,4 & 4,4 & 4,4 & 4,4 & 4,4 \\
\hline Gebied 6 & 1,7 & 0,0 & 1,1 & 0,0 & 2,0 & 0,0 & 2,2 & 0,0 & 2,2 & 0,0 & 1,3 & 0,0 & 2,2 & 0,0 & 2,0 & 0,0 & 1,1 \\
\hline 7 staand & 1,2 & 0,0 & 0,0 & 0,0 & 0,0 & 0,0 & 0,0 & 1,6 & 1,4 & 1,4 & 1,6 & 0,8 & 0,8 & 1,4 & 1,6 & 1,6 & 1,6 \\
\hline Gebied 8 & 0,0 & 0,2 & 0,2 & 0,0 & 0,0 & 0,0 & 0,0 & 0,0 & 0,0 & 0,0 & 0,0 & 0,0 & 0,0 & 0,0 & 0,0 & 0,0 & 0,0 \\
\hline HK-noordwest & 0,0 & 0,0 & 0,0 & 0,0 & 0,0 & 1,0 & 1,0 & 0,0 & 0,0 & 0,0 & 0,0 & 0,0 & 0,0 & 0,0 & 0,0 & 0,0 & 0,0 \\
\hline HK-zuidwest & 0,0 & 0,0 & 0,0 & 0,0 & 0,0 & 1,5 & 1,5 & 0,0 & 0,0 & 0,0 & 0,0 & 0,0 & 0,0 & 0,0 & 0,0 & 0,0 & 0,0 \\
\hline Totaal WOZ 2040/2050 & 8,8 & 19,1 & 19,2 & 18,4 & 18,5 & 17,4 & 17,6 & 13,7 & 12,7 & 12,6 & 14,5 & 14,5 & 14,6 & 12,1 & 12,2 & 15,2 & 15,3 \\
\hline
\end{tabular}

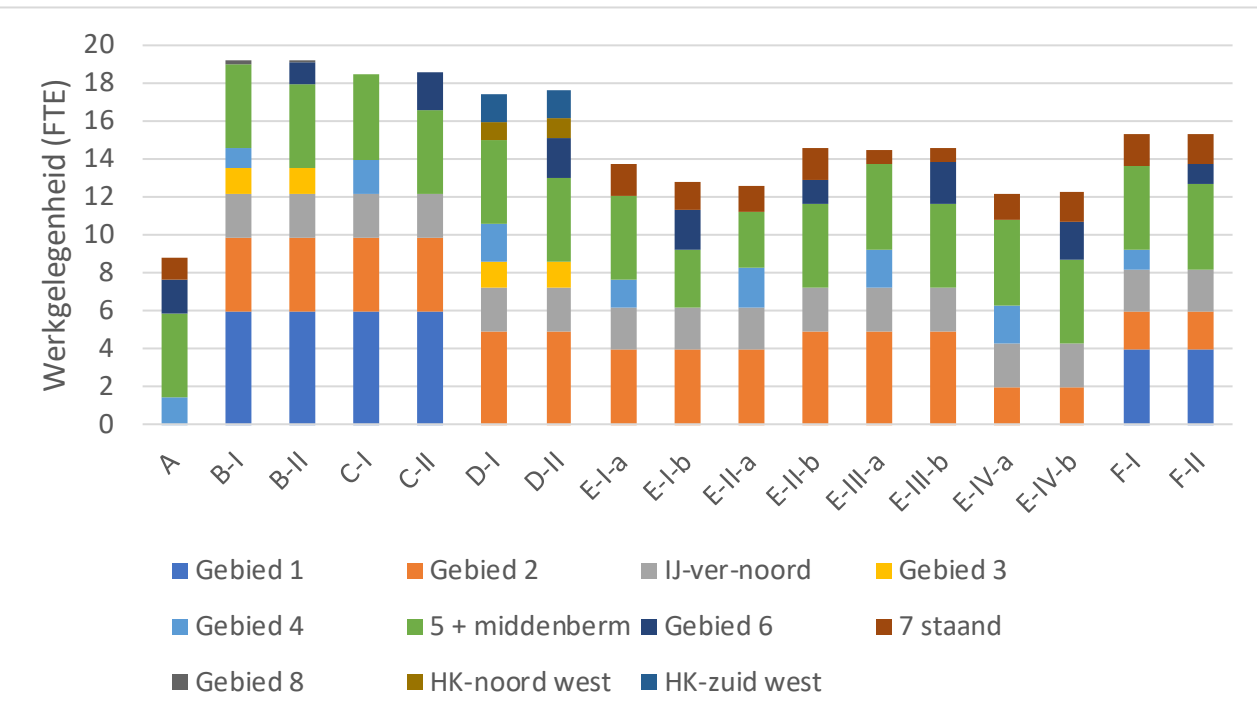

- De hier gepresenteerde werkgelegenheid is de opportunity cost van het in gebruik nemen van deze gebieden voor het exploiteren van WOZ.

- Gebieden HK-noordwest, IJ-ver-noord, HK-zuidwest, 1 en 2 zijn de gebieden met, relatief (per GW), de hoogste visserij werkgelegenheid (zie sectie 4.1).

De werkgelegenheid van visserij in de WOZ-zoekgebieden is het hoogst in de varianten $B, C$ en $D$.

- De werkgelegenheid van visserij in de WOZ-zoekgebieden is het laagst in de varianten A, E-IV-a/b, E-II-a en E-I-b.

Figuur 4.9 Directe werkgelegenheid (in fte/jaar) in visserij per WOZ-zoekgebied, voor varianten in 2040/2050 


\subsubsection{Scheepvaart}

Tabel 4.14 Mitigatiekosten (in $2017 \mathrm{mln}$. €/jaar) voor scheepvaart per WOZ-zoekgebied, voor varianten in 2040/2050

\begin{tabular}{|c|c|c|c|c|c|c|c|c|c|c|c|c|c|c|c|c|c|}
\hline Mitigatiekosten ( $\mathrm{mln} . \boldsymbol{\varepsilon})$ & A & B-I & B-II & C-I & C-II & D-I & D-II & E-I-a & E-I-b & E-II-a & E-II-b & E-III-a & E-IIII-b & E-IV-a & E-IV-b & F-I & F-II \\
\hline Gebied 1 & 0,0 & 11,6 & 11,6 & 11,6 & 11,6 & 0,0 & 0,0 & 0,0 & 0,0 & 0,0 & 0,0 & 0,0 & 0,0 & 0,0 & 0,0 & 7,7 & 7,7 \\
\hline Gebied 2 & 0,0 & 18,5 & 18,5 & 18,5 & 18,5 & 23,1 & 23,1 & 18,5 & 18,5 & 18,5 & 23,1 & 23,1 & 23,1 & 9,3 & 9,3 & 9,3 & 9,3 \\
\hline IJ-ver-noord & 0,0 & 5,4 & 5,4 & 5,4 & 5,4 & 5,4 & 5,4 & 5,4 & 5,4 & 5,4 & 5,4 & 5,4 & 5,4 & 5,4 & 5,4 & 5,4 & 5,4 \\
\hline Gebied 3 & 0,0 & 10,6 & 10,6 & 0,0 & 0,0 & 10,6 & 10,6 & 0,0 & 0,0 & 0,0 & 0,0 & 0,0 & 0,0 & 0,0 & 0,0 & 0,0 & 0,0 \\
\hline Gebied 4 & 13,2 & 9,4 & 0,0 & 34,0 & 0,0 & 37,8 & 0,0 & 13,2 & 0,0 & 37,8 & 0,0 & 37,8 & 0,0 & 37,8 & 0,0 & 9,4 & 0,0 \\
\hline $5+$ middenberm & 30,7 & 30,7 & 30,7 & 30,7 & 30,7 & 30,2 & 30,2 & 30,7 & 11,7 & 11,7 & 30,7 & 30,7 & 30,7 & 30,7 & 30,7 & 30,7 & 30,7 \\
\hline Gebied 6 & 15,2 & 0,0 & 9,5 & 0,0 & 17,1 & 0,0 & 19,0 & 0,0 & 19,0 & 0,0 & 11,4 & 0,0 & 19,0 & 0,0 & 17,1 & 0,0 & 9,5 \\
\hline 7 staand & 17,3 & 0,0 & 0,0 & 0,0 & 0,0 & 0,0 & 0,0 & 17,3 & 20,2 & 20,2 & 17,3 & 11,5 & 11,5 & 20,2 & 17,3 & 17,3 & 17,3 \\
\hline Gebied 8 & 0,0 & 16,9 & 16,9 & 0,0 & 0,0 & 0,0 & 0,0 & 0,0 & 0,0 & 0,0 & 0,0 & 0,0 & 0,0 & 0,0 & 0,0 & 0,0 & 0,0 \\
\hline HK-noordwest & 0,0 & 0,0 & 0,0 & 0,0 & 0,0 & 18,1 & 18,1 & 0,0 & 0,0 & 0,0 & 0,0 & 0,0 & 0,0 & 0,0 & 0,0 & 0,0 & 0,0 \\
\hline HK-zuidwest & 0,0 & 0,0 & 0,0 & 0,0 & 0,0 & 22,2 & 22,2 & 0,0 & 0,0 & 0,0 & 0,0 & 0,0 & 0,0 & 0,0 & 0,0 & 0,0 & 0,0 \\
\hline Totaal WOZ 2040/2050 & 76.4 & 103,1 & 103,1 & 100,2 & 83,3 & 147,4 & 128,6 & 85,2 & 74,8 & 93,6 & 87,9 & 108,6 & 89,8 & 103,3 & 79,8 & 79,9 & 79,9 \\
\hline
\end{tabular}

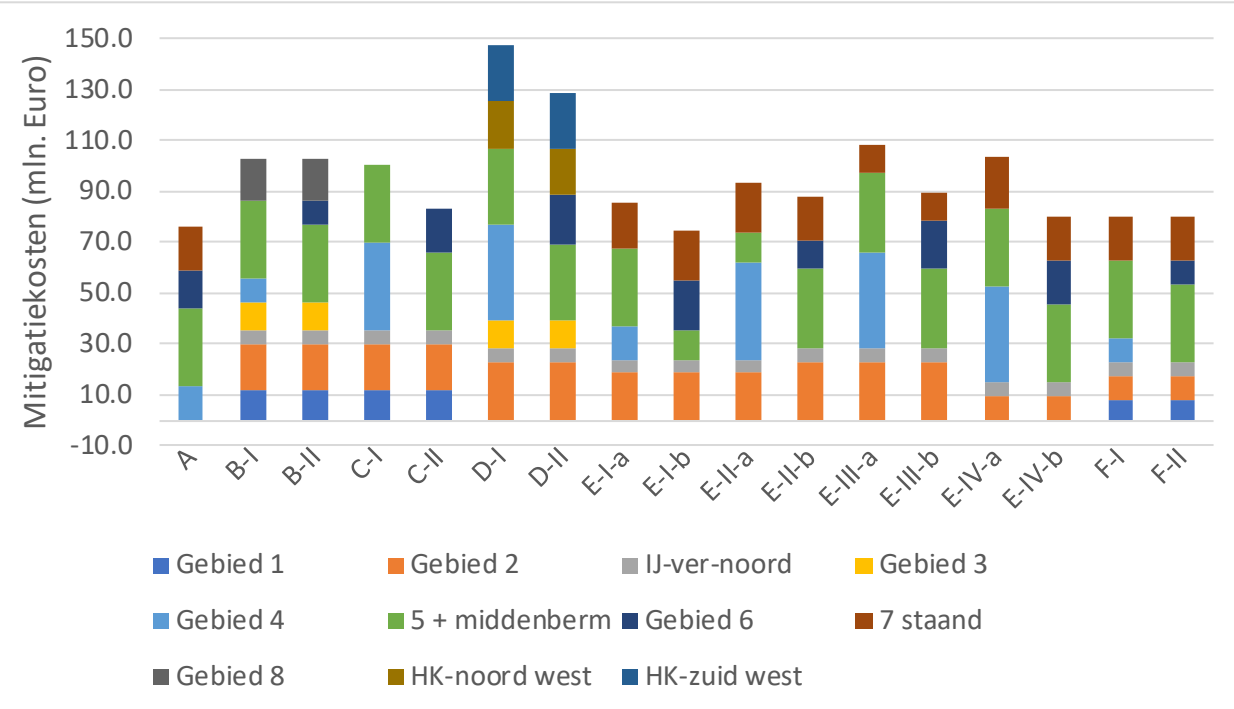

- De hier gepresenteerde scheepvaart mitigatiekosten zijn de opportunity costs van het in gebruik nemen van deze gebieden voor het exploiteren van WOZ.

- Gebieden HK-noordwest, HK-zuidwest en 8 zijn de gebieden met, relatief (per GW), de hoogste scheepvaart mitigatiekosten (zie sectie 4.1).

- De scheepvaart mitigatiekosten in de WOZ-zoekgebieden zijn het hoogst in de varianten D-I, D-II en E-III-a.

- De scheepvaart mitigatiekosten in de WOZ-zoekgebieden zijn het laagst in de varianten E-I-b, A en E-IV-b/F-I/F-II.

Figuur 4.10 Mitigatiekosten (in m/n. €/jaar) voor scheepvaart per WOZ-zoekgebied, voor varianten in 2040/2050 


\subsection{Per sector per variant}

De directe en indirecte economische waardes per sector en per variant (in termen van productiewaarde (PW), toegevoegde waarde (TW) en werkgelegenheid (FTE)) totaal voor de Noordzee, zijn berekend voor windmolenparkexploitatie (sectie 4.3.1), windmolenparkbouw (sectie 4.3.2) en visserij (sectie 4.3.3).

Met betrekking tot windmolenparkexploitatie (sectie 4.3.1), laten de resultaten voor directe en indirecte productiewaarde (PW), toegevoegde waarde (TW) en werkgelegenheid (FTE) zien dat (tabel 4.15 en figuur 4.11):

- De TW van windmolenparkexploitatie is het hoogst voor de varianten D-I, C-I en B-I (>340 mln. $€ /$ jaar).

- De TW van windmolenparkexploitatie is het laagst voor de varianten E-IV-b, E-I-b, F-II en E-II-b (<200 mln. €/jaar).

- De PW en werkgelegenheid van windmolenparkexploitatie varieert nauwelijks tussen varianten, want alle varianten tellen op tot $27 \mathrm{GW}$ en variaties worden alleen verklaard door verschillen in yields tussen WOZ-zoekgebieden.

Let wel: de rentabiliteit van windmolenparkexploitatie (i.e. een positieve exploitatie TW) is bepalend voor het exploiteren van windmolenparken op zee.

Samenvattend, de TW van windmolenparkexploitatie is het hoogst in de varianten D-I, C-I en B-I. De verschillen in TW tussen de varianten zijn groot (tot $\sim 230 \mathrm{mln}$. $€ /$ jaar).

Met betrekking tot windmolenparkbouw (sectie 4.3.2), laten de resultaten voor directe en indirecte productiewaarde (PW), toegevoegde waarde (TW) en werkgelegenheid (FTE) zien dat (tabel 4.16 en figuur 4.12):

- De TW van windmolenparkbouw is het hoogst voor de varianten E-IV-b, E-I-b en F-II ( $>\sim 890 \mathrm{mln}$. $€ /$ jaar).

- De TW van windmolenparkbouw is het laagst voor de varianten D-I, C-I en B-I ( $<\sim 860 \mathrm{mln} . € /$ jaar).

- De PW, TW en werkgelegenheid van windmolenparkbouw varieert weinig tussen varianten, want alle varianten tellen op tot $27 \mathrm{GW}$ en variaties worden alleen verklaard door verschillen tussen windmolenparken in bouwkosten voor funderingen en aanlanding.

Let wel: de rentabiliteit van windmolenparkexploitatie (i.e. een positieve exploitatie TW) is bepalend voor windmolenparkbouw.

Samenvattend, de TW van windmolenparkbouw is het hoogst in de varianten E-IV-b, E-I-b en F-II. De verschillen in TW tussen varianten zijn relatief klein (tot $\sim 45 \mathrm{mln}$. $€ /$ jaar). Hoge exploitatie TW correspondeert met lage bouw TW.

Met betrekking tot visserij (sectie 4.3.3), laten de resultaten voor directe en indirecte productiewaarde (PW), toegevoegde waarde (TW) en werkgelegenheid (FTE) zien dat (tabel 4.17 en figuur 4.13):

- De PW en TW van visserij in de overgebleven gebieden op de Noordzee zijn het hoogst voor varianten A, E-IV-a/b en E-II-a (>69 mln. $€ /$ jaar).

- De PW en TW van visserij in de overgebleven gebieden op de Noordzee zijn het laagst voor varianten B-I, B-II, C-I en C-II ( $<68 \mathrm{mln}$. $€ /$ jaar).

- De werkgelegenheid in visserij in de overgebleven gebieden op de Noordzee is het hoogst voor varianten A, E-IV-a/b, E-II-a en E-I-b.

Let wel: deze waardes hebben betrekking op de overgebleven visserij gebieden in 2040/2050.

Samenvattend, de TW van visserij in de overgebleven gebieden op de Noordzee is het hoogst in de in de varianten A, E-IV-a/b, E-II-a en E-I-b. De verschillen in TW tussen de varianten zijn zeer klein ( $<2 \mathrm{mln} . € /$ jaar). 


\subsubsection{Windmolenparkexploitatie}

Tabel 4.15 Directe en indirecte productiewaarde (PW; in mln. $€ /$ jaar), toegevoegde waarde (TW; in mln. $€ / j a a r)$ en werkgelegenheid (1000 FTE/jaar) van windmolenparkexploitatie (voor de additionele 27 GW) op de Noordzee, voor varianten in 2040/2050

\begin{tabular}{|c|c|c|c|c|c|c|c|c|c|c|c|c|c|c|c|c|c|c|}
\hline & & A & B-I & B-II & C-I & C-II & D-I & D-II & E-I-a & E-I-b & E-II-a & E-II-b & E-III-a & E-III-b & E-IV-a & E-IV-b & F-I & F-II \\
\hline PW & direct & 4.893 & 4.886 & 4.901 & 4.877 & 4.903 & 4.880 & 4.910 & 4.861 & 4.875 & 4.846 & 4.877 & 4.864 & 4.893 & 4.863 & 4.889 & 4.868 & 4.882 \\
\hline \multirow[t]{3}{*}{ (mln. $\mathbf{C} /$ jaar) } & indirect & PM & PM & PM & PM & PM & PM & PM & PM & PM & PM & PM & PM & PM & PM & PM & PM & PM \\
\hline & totaal & 4.893 & 4.886 & 4.901 & 4.877 & 4.903 & 4.880 & 4.910 & 4.861 & 4.875 & 4.846 & 4.877 & 4.864 & 4.893 & 4.863 & 4.889 & 4.868 & 4.882 \\
\hline & & $+P M$ & $+\mathrm{PM}$ & $+\mathrm{PM}$ & $+\mathrm{PM}$ & $+\mathrm{PM}$ & $+\mathrm{PM}$ & $+\mathrm{PM}$ & $+\mathrm{PM}$ & $+\mathrm{PM}$ & $+\mathrm{PM}$ & $+\mathrm{PM}$ & $+\mathrm{PM}$ & $+\mathrm{PM}$ & $+\mathrm{PM}$ & $+\mathrm{PM}$ & $+\mathrm{PM}$ & $+\mathrm{PM}$ \\
\hline TW & direct & 211 & 344 & 297 & 351 & 266 & 392 & 297 & 250 & 167 & 262 & 194 & 309 & 215 & 262 & 163 & 238 & 190 \\
\hline \multirow[t]{3}{*}{ (mln. $\mathrm{C} /$ jaar) } & indirect & PM & PM & PM & PM & PM & PM & PM & PM & PM & PM & PM & PM & PM & PM & PM & PM & PM \\
\hline & totaal & 211 & 344 & 297 & 351 & 266 & 392 & 297 & 250 & 167 & 262 & 194 & 309 & 215 & 262 & 163 & 238 & 190 \\
\hline & & $+\mathrm{PM}$ & $+\mathrm{PM}$ & $+\mathrm{PM}$ & $+\mathrm{PM}$ & $+\mathrm{PM}$ & $+\mathrm{PM}$ & $+\mathrm{PM}$ & $+\mathrm{PM}$ & $+\mathrm{PM}$ & $+\mathrm{PM}$ & $+\mathrm{PM}$ & $+\mathrm{PM}$ & $+\mathrm{PM}$ & $+\mathrm{PM}$ & $+\mathrm{PM}$ & $+P M$ & $+\mathrm{PM}$ \\
\hline FTE & direct & 3,46 & 3,36 & 3,39 & 3,35 & 3,41 & 3,26 & 3,33 & 3,43 & 3,49 & 3,42 & 3,47 & 3,38 & 3,45 & 3,42 & 3,49 & 3,43 & 3,47 \\
\hline (1.000 fte & indirect & PM & PM & PM & PM & PM & PM & PM & PM & PM & PM & PM & PM & PM & PM & PM & PM & PM \\
\hline \multirow[t]{2}{*}{ /jaar) } & totaal & 3,46 & 3,36 & 3,39 & 3,35 & 3,41 & 3,26 & 3,33 & 3,43 & 3,49 & 3,42 & 3,47 & $3,38+$ & 3,45 & 3,42 & 3,49 & 3,43 & 3,47 \\
\hline & & $+\mathrm{PM}$ & $+\mathrm{PM}$ & $+\mathrm{PM}$ & $+\mathrm{PM}$ & $+\mathrm{PM}$ & $+\mathrm{PM}$ & $+\mathrm{PM}$ & $+\mathrm{PM}$ & $+\mathrm{PM}$ & $+P M$ & $+\mathrm{PM}$ & PM & $+\mathrm{PM}$ & $+\mathrm{PM}$ & $+\mathrm{PM}$ & $+\mathrm{PM}$ & $+\mathrm{PM}$ \\
\hline
\end{tabular}
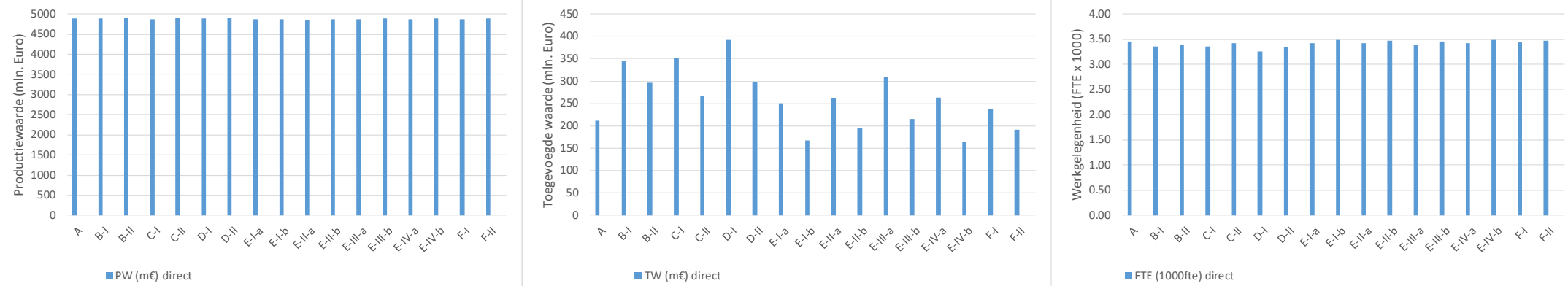

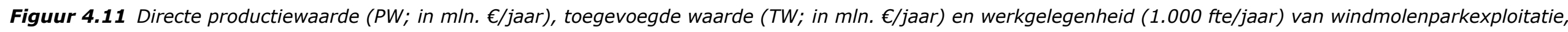
voor varianten in 2040/2050

- Let wel: de rentabiliteit van windmolenparkexploitatie (i.e. een positieve TW) is bepalend voor het exploiteren van windmolenparken op zee.

- De TW van windmolenparkexploitatie is het hoogst voor de varianten D-I, C-I en B-I (>340 m/n. $€ / j a a r)$.

- De TW van windmolenparkexploitatie is het laagst voor de varianten E-IV-b, E-I-b, F-II en E-II-b (<200 m/n. €/jaar).

- De PW en werkgelegenheid van windmolenparkexploitatie varieert nauwelijks tussen varianten (allen 27 GW; variatie door yield verschillen). 


\subsubsection{Windmolenparkbouw}

Tabel 4.16 Directe en indirecte productiewaarde ( $P W$; in $\mathrm{mln} . € / j a a r)$, toegevoegde waarde (TW; in mln. $€ / j a a r)$ en werkgelegenheid (1000 FTE/jaar) van windmolenparkbouw (voor de additionele $27 \mathrm{GW}$ ) op de Noordzee, voor varianten in 2040/2050

\begin{tabular}{|c|c|c|c|c|c|c|c|c|c|c|c|c|c|c|c|c|c|c|}
\hline & & A & B-I & B-II & C-I & C-II & D-I & D-II & E-I-a & $E-I-b$ & E-II-a & E-II-b & E-III-a & E-III-b & E-IV-a & $E-I V-b$ & $F-I$ & F-II \\
\hline PW & direct & 1.660 & 1.610 & 1.632 & 1.605 & 1.644 & 1.592 & 1.636 & 1.635 & 1.669 & 1.626 & 1.661 & 1.615 & 1.659 & 1.631 & 1.676 & 1.642 & 1.664 \\
\hline \multirow[t]{2}{*}{ (mln. $\mathrm{C} /$ jaar) } & indirect & 780 & 757 & 767 & 754 & 773 & 748 & 769 & 768 & 785 & 764 & 780 & 759 & 780 & 767 & 788 & 772 & 782 \\
\hline & totaal & 2.441 & 2.367 & 2.400 & 2.359 & 2.417 & 2.340 & 2.404 & 2.403 & 2.454 & 2.390 & 2.441 & 2.374 & 2.439 & 2.398 & 2.463 & 2.413 & 2.446 \\
\hline TW & direct & 604 & 586 & 594 & 584 & 598 & 579 & 595 & 595 & 607 & 591 & 604 & 587 & 603 & 593 & 609 & 597 & 605 \\
\hline \multirow[t]{2}{*}{ (mln. $\mathbf{c} /$ jaar) } & indirect & 284 & 275 & 279 & 274 & 281 & 272 & 280 & 279 & 285 & 278 & 284 & 276 & 284 & 279 & 286 & 281 & 284 \\
\hline & totaal & 888 & 861 & 873 & 858 & 879 & 851 & 874 & 874 & 892 & 869 & 888 & 863 & 887 & 872 & 896 & 878 & 889 \\
\hline FTE & direct & 3,80 & 3,69 & 3,73 & 3,69 & 3,76 & 3,59 & 3,67 & 3,77 & 3,84 & 3,76 & 3,81 & 3,72 & 3,80 & 3,76 & 3,84 & 3,78 & 3,82 \\
\hline (1.000 fte & indirect & 1,79 & 1,73 & 1,75 & 1,73 & 1,77 & 1,69 & 1,72 & 1,77 & 1,80 & 1,77 & 1,79 & 1,75 & 1,78 & 1,77 & 1,80 & 1,78 & 1,79 \\
\hline /jaar) & totaal & 5,59 & 5,43 & 5,48 & 5,42 & 5,52 & 5,28 & 5,39 & 5,54 & 5,64 & 5,52 & 5,61 & 5,47 & 5,58 & 5,52 & 5,64 & 5,55 & 5,61 \\
\hline
\end{tabular}

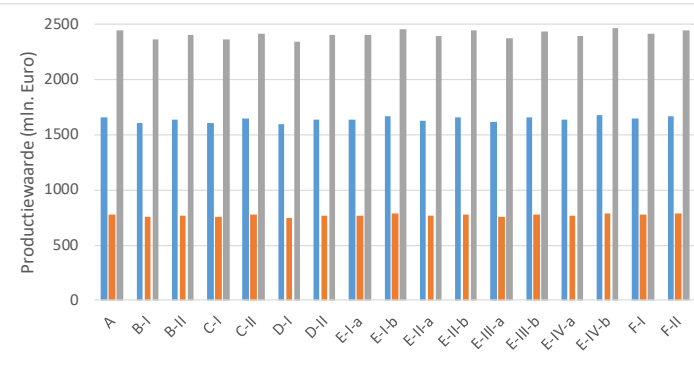

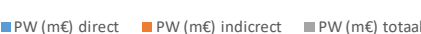

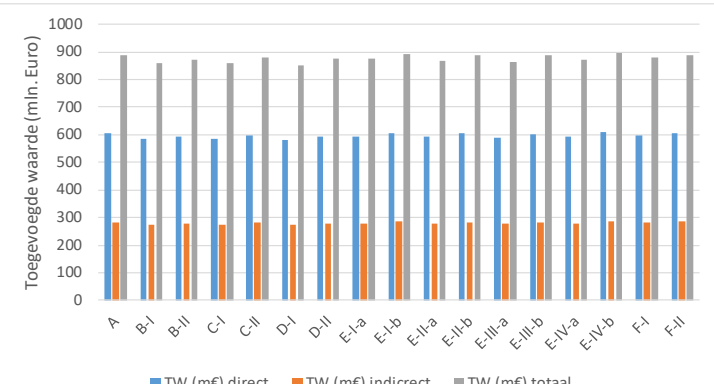

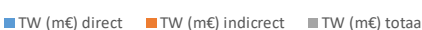

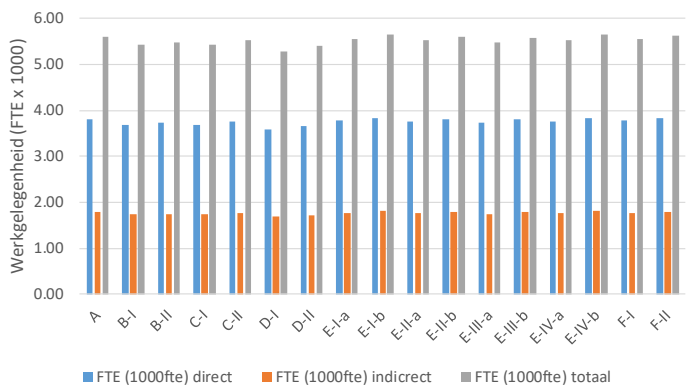

Figuur 4.12 Directe en indirecte productiewaarde (PW; in $\mathrm{mln} . € / j \mathrm{jaar})$, toegevoegde waarde (TW; in mln. $€ / j a a r)$ en werkgelegenheid (1000 FTE/jaar) van windmolenparkbouw, voor varianten in 2040/2050

- Let wel: de rentabiliteit van windmolenparkexploitatie (i.e. een positieve TW) is bepalend voor windmolenparkbouw.

- De TW van windmolenparkbouw is het hoogst voor de varianten E-IV-b, E-I-b en F-II (> 890 m/n. $€ / j a a r)$.

- De TW van windmolenparkbouw is het laagst voor de varianten D-I, C-I en B-I (< 860 m/n. $€ / j a a r)$.

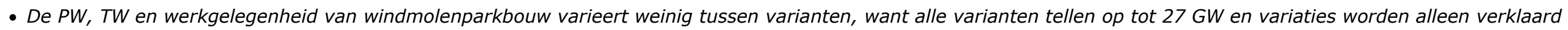
door verschillen in bouwkosten voor funderingen en aanlanding. 


\subsubsection{Visserij}

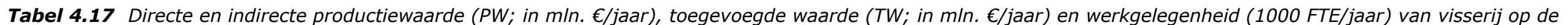
Noordzee, voor varianten in 2040/2050

\begin{tabular}{|c|c|c|c|c|c|c|c|c|c|c|c|c|c|c|c|c|c|c|}
\hline & & A & B-I & B-II & C-I & C-II & D-I & D-II & E-I-a & E-I-b & E-II-a & E-II-b & E-III-a & E-III-b & E-IV-a & E-IV-b & F-I & F-II \\
\hline PW & direct & 98 & 96 & 96 & 96 & 96 & 96 & 96 & 97 & 97 & 97 & 97 & 97 & 97 & 97 & 97 & 97 & 97 \\
\hline \multirow[t]{2}{*}{ (mln. $\mathbf{c} /$ jaar) } & indirect & 39 & 38 & 38 & 38 & 38 & 39 & 39 & 39 & 39 & 39 & 39 & 39 & 39 & 39 & 39 & 39 & 39 \\
\hline & totaal & 137 & 134 & 134 & 135 & 135 & 135 & 135 & 136 & 136 & 136 & 136 & 136 & 136 & 136 & 136 & 135 & 135 \\
\hline TW & direct & 50 & 49 & 49 & 49 & 49 & 49 & 49 & 49 & 49 & 49 & 49 & 49 & 49 & 49 & 49 & 49 & 49 \\
\hline \multirow[t]{2}{*}{ (mln. $\mathbf{C} /$ jaar) } & indirect & 20 & 20 & 19 & 20 & 20 & 20 & 20 & 20 & 20 & 20 & 20 & 20 & 20 & 20 & 20 & 20 & 20 \\
\hline & totaal & 69 & 68 & 68 & 68 & 68 & 69 & 69 & 69 & 69 & 69 & 69 & 69 & 69 & 69 & 69 & 69 & 69 \\
\hline FTE & direct & 0,49 & 0,48 & 0,48 & 0,48 & 0,48 & 0,48 & 0,48 & 0,49 & 0,49 & 0,49 & 0,48 & 0,48 & 0,48 & 0,49 & 0,49 & 0,48 & 0,48 \\
\hline (1.000 fte & indirect & 0,34 & 0,34 & 0,34 & 0,34 & 0,34 & 0,34 & 0,34 & 0,34 & 0,34 & 0,34 & 0,34 & 0,34 & 0,34 & 0,34 & 0,34 & 0,34 & 0,34 \\
\hline /jaar) & totaal & 0,83 & 0,82 & 0,82 & 0,82 & 0,82 & 0,82 & 0,82 & 0,82 & 0,83 & 0,83 & 0,82 & 0,82 & 0,82 & 0,83 & 0,83 & 0,82 & 0,82 \\
\hline
\end{tabular}

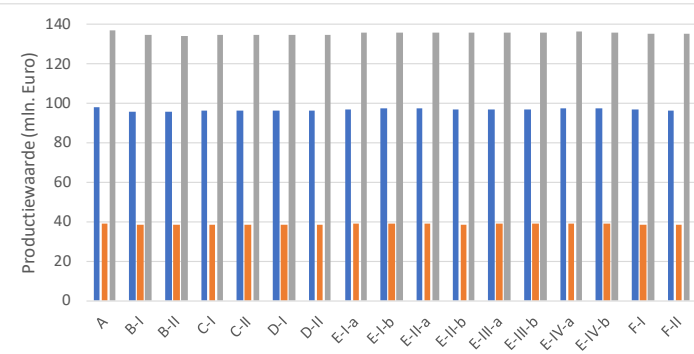

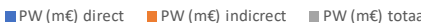

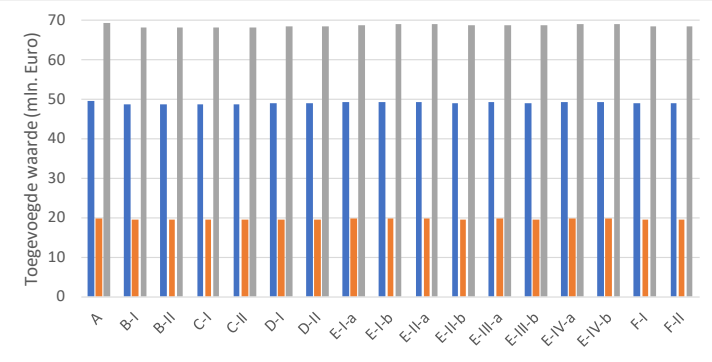

TW (me) direct

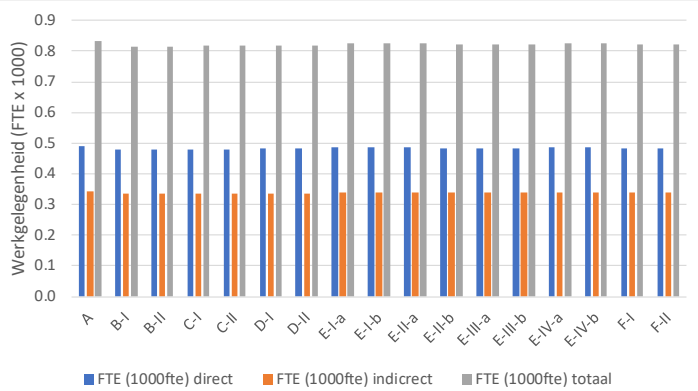

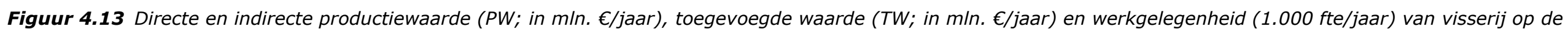
Noordzee, voor varianten in 2040/2050

- Deze waardes hebben betrekking op de overgebleven visserij gebieden in 2040/2050.

- De PW en TW van visserij in de overgebleven gebieden op de Noordzee zijn het hoogst voor varianten $A, E-I V-a / b$ en $E-I I-a$ (>69 mln. $€ / j a a r)$.

- De PW en TW van visserij in de overgebleven gebieden op de Noordzee zijn het laagst voor varianten B-I, B-II, C-I en C-II (<68 mIn. $€ / j a a r)$.

- De werkgelegenheid in visserij in de overgebleven gebieden op de Noordzee is het hoogst voor varianten A, E-IV-a/b, E-II-a en E-I-b. 


\section{Discussie, conclusies en aanbevelingen}

\subsection{Discussie}

Deze studie had tot doel een aanvullende economische kentallen analyse (Kentallen Analyse Mk.2) uit te voeren ter inschatting van de orde groottes van de economische effecten (in termen van productiewaarde, toegevoegde waarde, werkgelegenheid en mitigatiekosten) van de herijkte varianten en subvarianten voor de aanwijzing van windenergiegebieden (2040/2050) op de Noordzee, op windenergie, visserij en scheepvaart. De varianten hebben betrekking op een selectie van 4 tot 7 WOZ-zoek-gebieden, waarmee een extra capaciteit van $27 \mathrm{GW}$ wordt gerealiseerd (bovenop de huidige windparken $(1,0 \mathrm{GW})$ en de windparken die tot 2030 worden aangelegd $(11,5 \mathrm{GW})$ ).

Om inzicht te krijgen in welke varianten 2040/2050 de grootste economische baten en de kleinste economische kosten hebben, identificeren we:

1. Op kwalitatieve wijze de varianten met de grootste toegevoegde waarde (TW) in windmolenparkexploitatie en de varianten met de laagste visserij kosten (TW) en scheepvaart mitigatiekosten (tabel 5.1). Uit deze analyse blijkt dat er, op basis van de top-3 per gebruiksfunctie, geen varianten zijn die maximale windmolenparken exploitatie baten combineren met minimale visserij en scheepvaart kosten.

Tabel 5.1 Maximale (Max) toegevoegde waarden (TW) voor windmolenparken exploitatie (Expl), minimale (Min) toegevoegde waarde (TW) voor visserij en minimale mitigatiekosten voor scheepvaart, voor varianten in 2040/2050

\begin{tabular}{|l|l|l|l|l|l|l|l|l|l|l|l|l|l|l|l|l|l|}
\hline & A & B-I & B-II & C-I & C-II & D-I & D-II & E-I-a & E-I-b & E-II-a & E-II-b & E-III-a E-IIII-b & E-IV-a & E-IV-b & F-I & F-II \\
\hline Max Wind_Expl_TW & & $\mathrm{X}$ & & $\mathrm{X}$ & $\mathrm{X}$ & & & & & & \\
\hline Min_Visserij_TW & $\mathrm{X}$ & & & & & & & $\mathrm{X}$ & & $\mathrm{X}$ & $\mathrm{X}$ & \\
\hline Min_Scheep_Mitigatie & $\mathrm{X}$ & & & & & & $\mathrm{X}$ & & & & $\mathrm{X}$ & $\mathrm{X}$ & $\mathrm{X}$ \\
\hline
\end{tabular}

2. Op kwantitatieve wijze de windmolenparken toegevoegde waarde (TW) en de scheepvaart mitigatiekosten (Kosten), evenals het corresponderende verschil (figuur 5.1). Uit deze analyse blijkt dat de grootste nettowaardes worden verkregen voor de varianten C-I, D-I en B-I. Deze varianten hebben WOZ-zoekgebieden 2, IJ-ver-noord, 4 en 5+middenberm gemeen. Let wel, visserij zit niet in deze vergelijking want de TW van visserij in de corresponderende WOZzoekgebieden is zeer klein ( $<2 \mathrm{mln}$. $€ /$ jaar) ten opzichte van de respectievelijke TW van windmolenparkexploitatie ( $>163 \mathrm{mln}$. $€ /$ jaar) en scheepvaart mitigatiekosten ( $>75 \mathrm{mln}$. $€ /$ jaar).

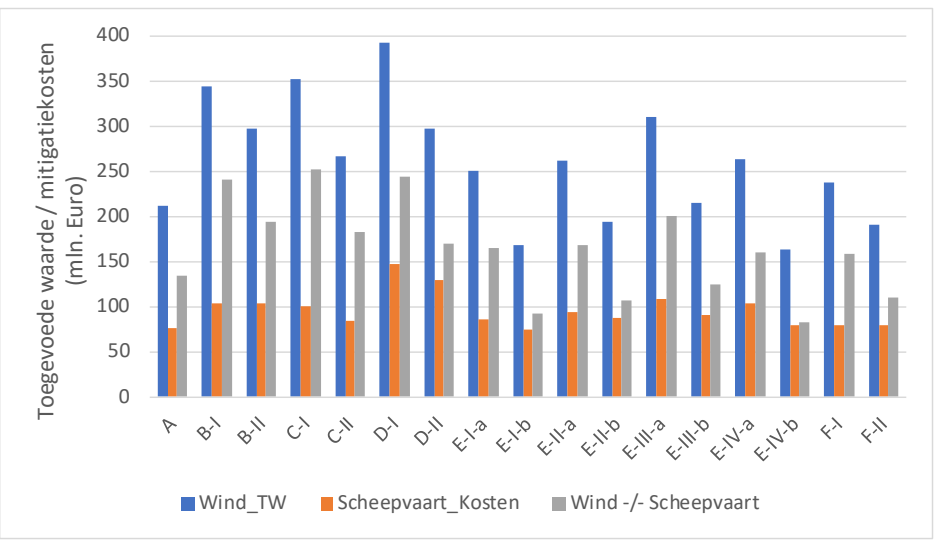

Figuur 5.1 Windmolenparken exploitatie toegevoegde waarden (TW), scheepvaart mitigatiekosten (Kosten) en bijbehorende verschillen, voor varianten in 2040/2050 


\subsection{Conclusies}

De resultaten laten zien dat de gederfde toegevoegde waarde van visserij in de WOZ-zoekgebieden zeer klein is ( $<2 \mathrm{mln}$. $€ /$ jaar) ten opzichte van de respectievelijke toegevoegde waardes van windmolenparkexploitatie ( $>163 \mathrm{mln}$. $€ /$ jaar) en scheepvaart mitigatiekosten ( $>75 \mathrm{mln}$. $€ /$ jaar). Verder blijkt dat de windmolenparken met, relatief (per GW), de hoogste exploitatie toegevoegde waarde (WOZ-zoekgebieden HK-noordwest, HK-zuidwest, 5+middenberm en 2) grotendeels overeenkomen met de windmolenparken met, relatief (per GW), de hoogste gederfde toegevoegde waarde voor visserij (WOZ-zoekgebieden HK-noordwest, HK-zuidwest, 1 en IJ-ver-noord) en de hoogste mitigatiekosten voor scheepvaart (WOZ-zoekgebieden HK-noordwest, HK-zuidwest en 8). Aldus zijn er geen WOZ-zoekgebieden die maximale windmolenparkexploitatie baten combineren met minimale visserij en scheepvaart kosten.

De rentabiliteit van windmolenparkexploitatie (i.e. een positieve exploitatie toegevoegde waarde) is bepalend voor het exploiteren van windmolenparken op zee. Op basis van de hoogste toegevoegde waarde voor windmolenparkexploitatie en de laagste gederfde toegevoegde waarde (visserij) en mitigatiekosten (scheepvaart), worden de grootste netto economische waardes verkregen voor de varianten C-I, D-I en B-I. Deze varianten hebben WOZ-zoekgebieden 2, IJ-ver-noord, 4 en $5+$ middenberm gemeen. Echter, ook hier zijn er geen varianten die maximale windmolenparken exploitatie baten combineren met minimale visserij en scheepvaart kosten. Een optimalisatie routine zou nuttig zijn in het identificeren van varianten (i.e. combinaties van WOZ-zoekgebieden) die maximale windmolenparken exploitatie baten combineren met minimale visserij en scheepvaart kosten.

\subsection{Aanbevelingen}

Om de economische effecten voor WOZ-zoekgebieden, varianten en subvarianten door te rekenen hebben we in deze studie veel gebruikgemaakt van aannames, uitgangspunten en cijfers gebaseerd op de door ons geraadpleegde bronnen. Gezien de beschikbare informatie en de inherente onzekerheid die hoort bij toekomstscenario's, kunnen de in deze studie gepresenteerde getallen en berekeningen daarom alleen worden beschouwd als aanduiding van ordegroottes, relatieve verschillen en verwachte ontwikkelingen in en tussen de varianten en subvarianten.

Deze studie is uitgevoerd op basis van bestaande gegevens, gecombineerd met de uitgangspunten per WOZ-zoekgebied en per variant. Een aantal posten kon echter niet of niet goed worden gekwantificeerd; hiervoor zijn PM-posten opgenomen. Met het opnemen van deze PM-posten vallen de cumulatieve cijfers uit de samenvattende tabellen lager uit dan daadwerkelijk zou mogen worden verwacht. Daarnaast omvatten de meegenomen indirecte effecten de aanvoer van goederen en diensten voor gebruiksfuncties op zee, maar niet de indirecte effecten die ontstaan als gevolg van afvoer/verwerking van goederen en diensten vanuit gebruiksfuncties op zee. Ook hiermee vallen de cumulatieve cijfers lager uit dan daadwerkelijk zou mogen worden verwacht. Daarom dienen de berekende getallen in deze verkenning gezien te worden als een indicatie van de ondergrens voor de mogelijke economische effecten en geeft deze studie inzicht in de richting van de economische effecten evenals de contouren van de mogelijke omvang van deze effecten.

De belangrijkste bron om de indirecte effecten te bepalen is de Maritieme Monitor (Ecorys, 2018). Hierin zijn op basis van input-outputmodellen berekeningen gemaakt voor de indirecte effecten per maritieme sector. Daarbij worden de indirecte effecten in deze bron voor de huidige situatie met een bepaalde verhouding weergegeven. Die verhoudingen hebben wij ook in dit rapport toegepast en nemen aan dat deze verhoudingen ongewijzigd blijven. In hoeverre deze verhoudingen nog hetzelfde zouden zijn in 2040/2050 staat, echter, niet in die bron vermeld. In de Maritieme Monitor wordt ook aangegeven dat alle individuele indirecte effecten niet per definitie kunnen worden opgeteld om daarmee het totaal aan indirecte effecten te berekenen. De reden hiervoor is dat er ook sprake is van onderlinge leveringen tussen sectoren binnen de clusters en het feit dat een aantal 'subsectoren' soms in twee sectoren wordt meegeteld. Het totaal van de indirecte effecten voor de gehele maritieme cluster (de focus van de Maritieme Monitor) ligt dus lager dan de som van de afzonderlijke sectoren. 
Aangezien windenergie op zee in 2040/2050 de grootste economische gebruiksfunctie is, zal een afwijking van de aannames in de berekeningen voor deze gebruiksfunctie grote consequenties hebben voor de totaalresultaten. Zo zullen, bijvoorbeeld, aannames over het rendement, de prijs ( $\mathrm{kWh}$ eurocent) en de relatieve bijdrage van de activiteit aan de Nederlandse economie, grote consequenties voor de totaalresultaten hebben. Voor andere gebruiksfuncties zijn de aannames met meer onzekerheid omgeven, maar de economische omvang van deze gebruiksfuncties is in 2040/2050 kleiner en daarmee ook het effect op het totaalresultaat.

In deze studie is voor de gebruiksfunctie visserij uitsluitend berekend wat de gemiddelde (over de periode 2010 tot en met 2019) waarde is van de gebieden die in varianten en subvarianten in (2040/2050) niet meer bevist kunnen worden. De varianten geven echter geen toekomstvoorspelling: het is onzeker wat vissers doen met het sluiten van de gebieden en gegeven de ontwikkelingen in de toekomst. De daadwerkelijke effecten in 2040/2050 zullen afhangen van in hoeverre de vissers zich verplaatsen naar andere gebieden, mogelijke saneringsregelingen, Brexit, natuurbehoud en WOZ ontwikkeling van andere landen op de Noordzee, etc.. Bovendien is de economische impact van de in de varianten geschetste ontwikkelingen op de visserij en de gevolgen hiervan voor de Nederlandse visserijcluster (inclusief handel \& verwerking) en visserijgemeenschappen niet in deze studie meegenomen. Zie voor de sociaaleconomische waarde van de WOZ-zoekgebieden en de invloed van de Brexit voor de Nederlandse visserij in 2030-2050, het rapport van Deetman et al. (2020).

In deze analyse zijn de mogelijke natuureffecten en de kosten om deze natuureffecten te mitigeren niet meegenomen. Mitigerende maatregelen houden, bijvoorbeeld, in dat windmolens tijdelijk worden stilgezet - hetgeen leidt tot een reductie in de yield. Het is op dit moment, echter, onduidelijk welke windmolenparken, wanneer en hoe lang stilgelegd moeten worden om natuureffecten te mitigeren.

Met betrekking tot aanlandingskosten ('grid connection system'), deze zijn op basis van de huidig beschikbare gegevens (BLIX, 2020) relatief hoog ingeschat - ongeveer $25 \%-33 \%$ van de totale productiekosten. Dit heeft met name invloed op de verder afgelegen WOZ-zoekgebieden. Het kan, echter, zijn dat innovaties in aanlandings-technologieën leiden tot lagere aanlandingskosten in de toekomst. De resultaten van NSE (2020) laten, bijvoorbeeld, zien dat er mogelijk kostenvoordelen zijn te behalen op systeemniveau door het offshore produceren van waterstof. Gezien de huidige onzekerheden over kosten- en opbrengsten-schattingen is, echter, het advies dat de opties (waterstofproductie op land of op zee) als kostenneutraal kunnen worden beschouwd. 


\section{Referenties}

BLIX, 2020. Determination of the cost levels of wind farms (and their grid connections) in new offshore wind energy search areas. Report WOZ2180096, BLIX Consultancy, Utrecht, Nederland. 97 pp.

CBS, 2016. Economic description of the Dutch North Sea and Coast: 2005, 2010, 2014. Online: https://www.cbs.nl/-/media/_pdf/2017/22/170530\%20economic-description-of-the-dutch-northsea-and-coast-2005-2010-2014.pdf.

Deetman, B., A.Y. Eweg, J.A.E. van Oostenbrugge, A. Mol, K.G. Hamon \& N.A. Steins, 2020. Inzicht in de sociaal-economische waarde van de zoekgebieden windenergie op de Noordzee 2030-2050 voor de Nederlandse visserij. Rapport 2020-125, Wageningen Economic Research, Wageningen, Nederland. URL: https://doi.org/10.18174/536640.

Ecorys, 2017. Maritieme Monitor 2017. Online: https://www. maritiemland.nl/download-digitale-versierapport-maritieme-monitor-2017/.

Ecorys, 2018. Maritieme Monitor 2018. Online: http://www. maritiemland.nl/downloadlink. php?file=wp-content/uploads/2018/11/NML-v.4-Eindrapportage-Maritieme-Monitor-2018-2410-2018.pdf.

EIB, 2016. Energieakkoord. Effecten van de energietransitie op de inzet en kwaliteit van arbeid. Online: https://www.energieakkoordser.nl/ /media/files/energieakkoord/nieuwsberichten/2016/inzetkwaliteit-arbeid-eib.ashx.

EZK, 2018. Structuurvisie Windenergie op Zee. Ministerie van Economische Zaken (EZK), Den Haag, Nederland. 13pp. Online:

https://www.tweedekamer.nl/kamerstukken/brieven_regering/detail?id=2018Z05409\&did=2018D21 716.

Hintzen, N.T., F. Bastardie, D.J. Beare, G.J. Piet, C. Ulrich, N. Deporte, J. Egekvist en H. Degel, 2012. VMStools: Open-source software for the processing, analysis and visualisation of fisheries logbook and VMS data. Fisheries Research, 115-116: 31-43.

Knol, E \& J. Baken, 2018. Invulling groeiende arbeidsvraag in offshore windsector vanuit offshore olieen gassector. Online:

https://www.topsectorenergie.nl/sites/default/files/uploads/Wind\%20op\%20Zee/Documenten/2018 01_RAP_Invulling-groeiende-arbeidsvraag-in-offshore-windsector-vanuit-offshore-olie-en-gas. pdf.

Matthijsen, J., E. Dammers \& H. Elzenga, 2018. De toekomst van de Noordzee - de Noordzee in 2030 en 2050: een scenariostudie. Publicatie 2728, Planbureau voor de Leefomgeving (PBL), Den Haag, Nederland.

Matthijsen, J., E. Dammers \& H. Elzenga, 2019. Achtergronden bij de toekomst van de Noordzee: onderliggende gegevens en aannames. Publicatie 3177, Planbureau voor de Leefomgeving (PBL), Den Haag, Nederland.

Navigant, 2019. Connecting offshore wind farms - a comparison of offshore electricity grid development models in Northwest Europe. Navigant, Utrecht, Nederland.

NSE, 2020. Memo: offshore waterstofproductie. North Sea Energy (NSE), Alkmaar, Nederland. 3 pp.

PROMOTION, 2016. Deliverable 1.3: Synthesis of available studies on offshore meshed HVDC grids. Deliverable 1.3, Progress on Meshed HVDC Offshore Transmission Networks (PROMOTioN), EUHorizon 2020. 143 pp.

PWC, 2018. De economische bijdrage van windenergie op zee. Online: https://www.rijksoverheid.nl/documenten/rapporten/2018/08/31/de-economische-bijdrage-vanwindenergie-op-zee.

Roebeling, P.C., Strietman, W.J., Jongbloed, R., et al., 2021. De economische en ecologische effecten van inrichtingsvarianten voor de Noordzee tot 2040/2050. Rapport 2021-063, Wageningen Economic Research, Wageningen, Nederland. URL: https://doi.org/10.18174/548296.

RWS-ZD, 2020. Mitigerende maatregelen scheepvaart voor wind-op-zee zoekgebieden op de Noordzee. Rijkswaterstaat Zee en Delta (RWS-ZD), Middelburg, Nederland. 7 pp.

Strietman, W.J., K.G. Hamon \& A. Mol, 2019. De economische effecten van twee toekomstscenario's voor de Noordzee. Rapport 2019-080, Wageningen Economic Research, Wageningen, Nederland. URL: https://doi.org/10.18174/495958. 
Wageningen Economic Research Postbus 29703

2502 LS Den Haag

T 0703358330

Ecommunications.ssg@wur.nl

www.wur.nl/economic-research

Wageningen Economic Research RAPPORT

2021-069
De missie van Wageningen University \& Research is 'To explore the potential of nature to improve the quality of life'. Binnen Wageningen University \& Research bundelen Wageningen University en gespecialiseerde onderzoeksinstituten van Stichting Wageningen Research hun krachten om bij te dragen aan de oplossing van belangrijke vragen in het domein van gezonde voeding en leefomgeving. Met ongeveer 30 vestigingen, 6.800 medewerkers (6.000 fte) en 12.900 studenten behoort Wageningen University \& Research wereldwijd tot de aansprekende kennisinstellingen binnen haar domein. De integrale benadering van de vraagstukken en de samenwerking tussen verschillende disciplines vormen het hart van de unieke Wageningen aanpak. 



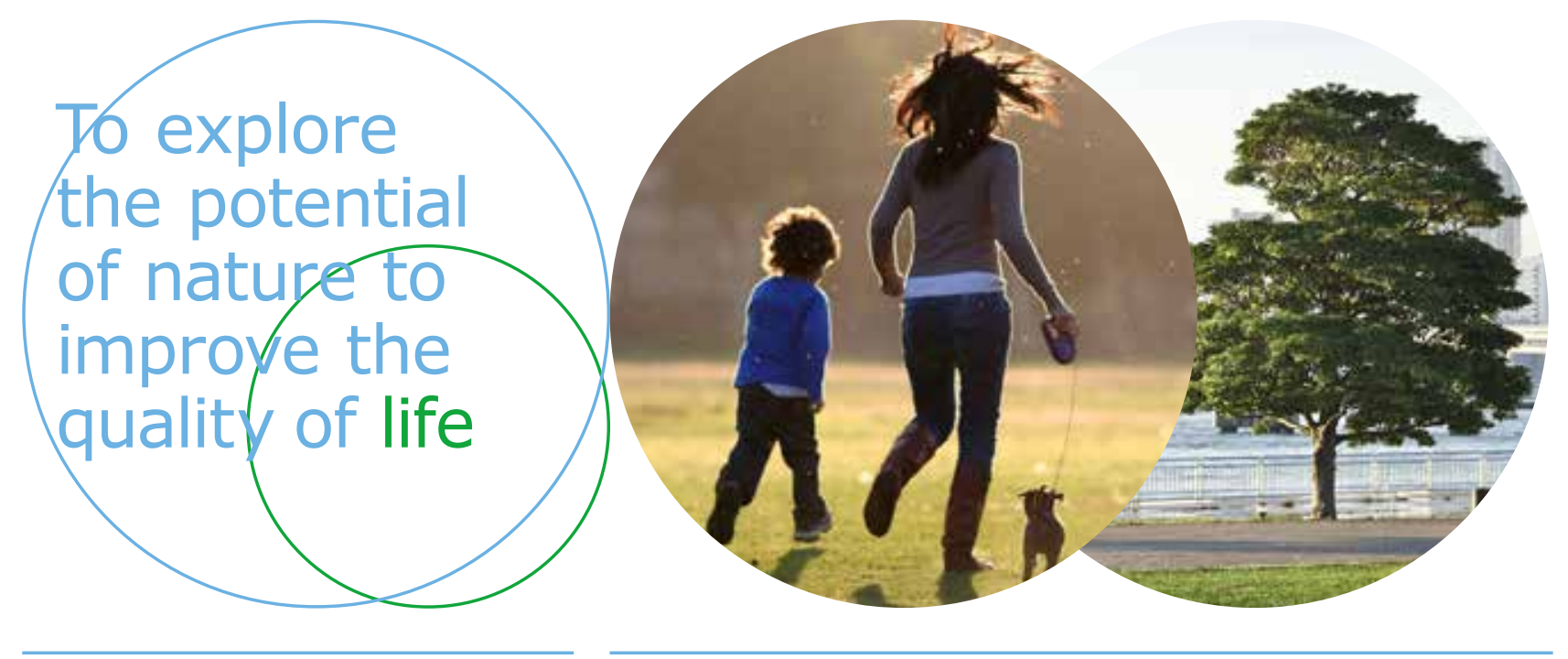

Wageningen Economic Research Postbus 29703

2502 LS Den Haag

T 0703358330

E communications.ssg@wur.nl www.wur.nl/economic-research

Rapport 2021-069

ISBN 978-94-6395-858-5
De missie van Wageningen University \& Research is 'To explore the potential of nature to improve the quality of life'. Binnen Wageningen University \& Research bundelen Wageningen University en gespecialiseerde onderzoeksinstituten van Stichting Wageningen Research hun krachten om bij te dragen aan de oplossing van belangrijke vragen in het domein van gezonde voeding en leefomgeving. Met ongeveer 30 vestigingen, 6.800 medewerkers ( $6.000 \mathrm{fte}$ ) en 12.900 studenten behoort Wageningen University \& Research wereldwijd tot de aansprekende kennisinstellingen binnen haar domein. De integrale benadering van de vraagstukken en de samenwerking tussen verschillende disciplines vormen het hart van de unieke Wageningen aanpak. 